\title{
Sedimentary-volcanic successions of the Alta-Kvænangen Tectonic Window in the northern Norwegian Caledonides: Multiple constraints on deposition and correlation with complexes on the Fennoscandian Shield
}

\author{
Victor A. Melezhik', Bernard Bingen', Jan Sverre Sandstad', Boris. G. Pokrovsky², \\ Arne Solli', Anthony E. Fallick ${ }^{3}$ \\ ${ }^{1}$ Geological Survey of Norway, Postbox 6315 Sluppen, 7491, Trondheim, Norway. \\ ${ }^{2}$ Geological Institute, Russian Academy of Sciences, Pyzhevsky drive, 7, 109017, Moscow, Russia. \\ ${ }^{3}$ Scottish Universities Environmental Research Centre, Rankine Avenue, East Kilbride, Scotland. G75 0QF. \\ E-mail corresponding author (Victor A. Melezhik): victor.melezhik@ngu.no
}

\begin{abstract}
Airborne geophysical data, sedimentological and geochemical characteristics of carbonate rocks, geochemical features of igneous rocks, carbon isotope chemostratigraphy and radiometric dating form a multiple approach applied for the reconstruction of depositional environments and the age of the sedimentary-volcanic succession exposed in the Alta-Kvænangen Tectonic Window (AKTW) in the northern Norwegian Caledonides. Aeromagnetic geophysical data confirm that the AKTW succession continues beneath the Caledonian nappe complexes and connects with the Kautokeino Greenstone Belt in the main part of the Fennoscandian Shield. The carbonate rocks, mainly dolostones, of the Kvenvik formation are markedly enriched in ${ }^{13} \mathrm{C}\left(\delta^{13} \mathrm{C}=+7.4 \pm 0.7 \%\right.$, $\left.\mathrm{n}=51\right)$ and record a global positive excursion of carbonate carbon isotopes in sedimentary carbonates known as the Lomagundi -Jatuli isotopic event whose duration was constrained in the Fennoscandian Shield between $c .2220$ and $2060 \mathrm{Ma}$. A radiometric date of $2146 \pm 5 \mathrm{Ma}$ (U-Pb, zircon) obtained from a gabbro comagmatic with mafic lavas provides a minimum age for the deposition of the ${ }^{13} \mathrm{C}$-rich, Lower and Upper dolostones and the accumulation age of the ${ }^{13} \mathrm{C}$-rich Uppermost dolostone. The carbonate rocks of the structurally overlying Storviknes formation show near-zero $\delta^{13} \mathrm{C}(+1.1 \pm 1.2 \%, \mathrm{n}=41)$. Carbon isotope chemostratigraphy suggests that their deposition post-dated $2060 \mathrm{Ma}$ which, together with the above mentioned radiometric date, indicates a non-depositional break/hiatus of over $80 \mathrm{Myr}$ separating accumulation of the two neighbouring formations. Sedimentological features of the carbonate rocks are consistent with deposition in a carbonate platform/shelf, whereas the depositional features of shales suggest accumulation in a shallow-water epeiric sea. The ${ }^{13} \mathrm{C}$-rich dolostones of the Kvenvik formation contain plentiful halite casts and sulphate pseudomorphs reflecting formation of abundant CaSO and $\mathrm{NaCl}$ in time-equivalent successions across the Fennoscandian Shield, which may represent a source for $\mathrm{Na}$ and $\mathrm{Cl}$ metasomatism that affected Palaeoproterozoic rocks in the AKTW and across northern Fennoscandia.
\end{abstract}

Keywords: Caledonides, Norway, carbon isotopes, carbonates, evaporites, Palaeoproterozoic

Received 11. March 2015 / Accepted 1. May 2015 / Published online 20. June 2015

\section{Introduction}

Several tectonic windows in the northern Norwegian Caledonides represent an apparent northwestern continuation of the Precambian Fennoscandian Shield beneath the Caledonian nappes. The Alta-Kvænangen Tectonic Window (AKTW) is one such window (Figs. 1 \& 2). It contains several informally established formations with diverse lithologies of metamorphosed sedimentary rocks associated with abundant mafic extrusive and intrusive rocks (Zwaan \& Gautier, 1980; Pharaoh et al., 1983; Bergh \& Torske, 1986, 1988).

There have been several attempts to correlate sedimentary and volcanic sequences of the AKTW with those occurring in other tectonic windows as well as in the main part of Fennoscandian Shield (e.g., Pharaoh et al., 1983; Siedlecka et al., 1985; Bergh \& Torske, 1986, 1988). These correlations are largely based

Melezhik, V.A., Bingen, B., Sandstad, J.S., Pokrovsky, B.G., Solli, A. \& Fallick, A.E. 2015: Sedimentary-volcanic successions of the Alta-Kvænangen Tectonic Window in the Northern Norwegian Caledonides: Multiple constraints on deposition and correlation with the Fennoscandian Shield. Norwegian Journal of Geology 95, 245-284. http://dx.doi.org/10.17850/njg95-3-01.

(C) Copyright the authors.

This work is licensed under a Creative Commons Attribution 4.0 International License. 
on lithological characteristics of sedimentary rocks and geochemical signatures of volcanic units. They demonstrated some similarities of the AKTW rock complex with those occurring across northern Norway, and consequently resulted in the general acceptance of their Palaeoproterozoic age. However, to date, there are no actual radiometric dates available which can provide robust constraints on the age of deposition of the AKTW rock successions.

Here, we use sedimentological constraints, carbon isotope chemostratigraphy, $\mathrm{U}-\mathrm{Pb}$ radiometric dating of a gabbro, and airborne geophysical data to provide the first insight into the depositional history of the AKTW rock successions and their correlation with the sedimentaryvolcanic formations across the Fennoscandian Shield. These correlations are used for placing the palaeogeographic and palaeotectonic positions of the AKTW rocks within the framework of the evolution of the shield in northern Fennoscandia.

\section{Geological background}

Sedimentary and volcanic rocks occurring in the AKTW constitute the Raipas Supergroup whose base remains unknown. The supergroup has been subdivided into four informal formations (Zwaan \& Gautier, 1980). It starts with the Kvenvik formation which has a cumulative thickness of over $2200 \mathrm{~m}$ (Fig. 3). Based on lithological composition, the formation can be further subdivided into two units. The lower unit $(>1000 \mathrm{~m})$, defined by Vik (1985) as the Lower Kvenvik greenstone formation (Member A hereafter), is composed mainly of gabbro and subordinate dolostone, albite felsites, shale, albitecarbonate-magnetite rock, and mafic tuff and tuffite. The upper unit (c. $1200 \mathrm{~m}$ ), defined by Vik (1985) as the Upper Kvenvik greenstone formation (Member B hereafter), consists mainly of mafic tuff, massive and pillowed tholeiitic basalt, subordinate dolostone, limestone and black shale (Bergh \& Torske, 1988).

The Kvenvik formation is overlain by the Storviknes formation (300-600 m), composed of dolostones with stromatolites, dolostone breccias, and purple and grey siltstone (Bergh \& Torske, 1988). The major dolostone unit occurring at Raipas and Borras hosts copper deposits, and several copper showings also occur in the upper and thinner dolostone unit interbedded with siltstone (Fig. 3).

TheStorviknes formation is succeeded by theSkoađđovárri formation, a c. $1700 \mathrm{~m}$-thick unit composed mainly of sandstone containing interbeds of conglomerate, pebbly sandstone and shale (Zwaan \& Gautier, 1980; Bergh \& Torske, 1986).

The youngest unit in the Raipas Supergroup is the Luovosvárri formation (Zwaan \& Gautier, 1980). It is composed of dolostone and sandstone. The sedimentary and volcanic rocks of the Raipas Supergroup are tectonically deformed and metamorphosed at greenschist facies. The Raipas Supergroup is unconformably overlain by the Bossekop Group, comprising stromatolitic dolostone and siltstone, followed by the Borras Group which consists of sandstone, siltstone, conglomerate and tillite of inferred Late Neoproterozoic age (Fig. 2; Zwaan \& Gautier, 1980).

Several minor copper deposits, partly mined in the past, are known in the Raipas Supergroup. In the lower part of the Kvenvik formation, copper sulphide occurs as disseminations in albite felsites and as hydrothermal sulphide-quartz-carbonate veins in volcanic rocks throughout the formation. Sediment-hosted copper deposits are also widespread in the Storviknes formation (e.g., Vik, 1985). Here, copper sulphides occur as cement in breccias and disseminations in dolostone and shale lithologies (Fig. 3).

\section{Analytical methods}

Major and trace elements were analysed at the Geological Survey of Norway (NGU), Trondheim, by a PANalytical Axios at $4 \mathrm{~kW}$ X-ray spectrometer. The precision $(1 \sigma)$ is typically around $2 \%$ of the major oxide present. For marble samples, elemental concentrations were determined on acidified extracts of whole-rock (cold 10\% $\mathrm{HCl})$ by inductively coupled plasma-atomic emission spectrometry (ICP-AES) using a Thermo Jarell Ash ICP 61. Detection limits for Fe, Mg, Ca and Mn are 5, 100, 200 and $0.2 \mu \mathrm{g} / \mathrm{g}$, respectively. The total analytical uncertainty including element extraction $(1 \sigma)$ is $\pm 10 \%$ rel.

Stable carbon and oxygen isotope analyses were performed at the Scottish Universities Environmental Research Centre (SUERC) in Glasgow and at the Geological Institute of the Russian Academy of Sciences in Moscow. Approximately $1 \mathrm{mg}$ powder was reacted overnight with phosphoric acid at $70^{\circ} \mathrm{C}$. Ratios were measured on PRISM III, AP2003 and DELTA V mass spectrometers. Repeat analyses of NBS-19 and internal calcite standards are generally better than $\pm 0.2 \%$ for carbon and $\pm 0.3 \%$ for oxygen, and interlaboratory differences are within these ranges. Carbon and oxygen isotopic values are reported and discussed in the conventional delta notation relative to $\mathrm{V}-\mathrm{PDB}$ and $\mathrm{V}-\mathrm{SMOW}$, respectively.

Zircons for $\mathrm{U}-\mathrm{Pb}$ geochronology were extracted from one crushed sample, using a water table followed by separation in heavy liquids and magnetic field. Zircon crystals selected for radiometric dating were mounted in epoxy together with the reference material, and polished to approximately half thickness. The grains were imaged individually with a panchromatic cathodoluminescence (CL) detector in a variable pressure Scanning Electron Microscope at NGU. U-Pb analyses were performed by Secondary Ion Mass Spectrometry (SIMS) with 


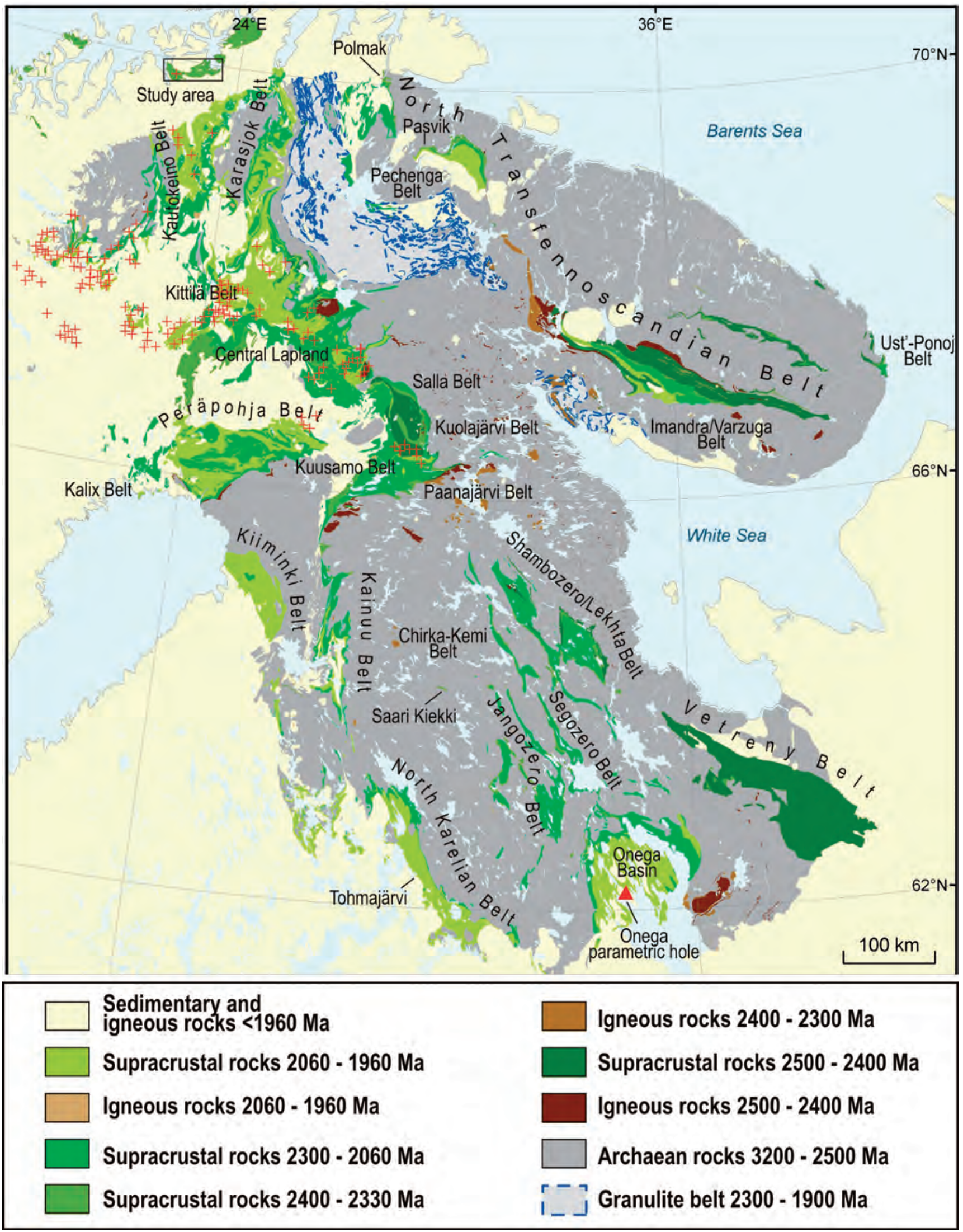

Figure 1. Geological map of the eastern part of the Fennoscandian Shield emphasising the Early Palaeoproterozoic rocks and showing the location of the study area (in the northwest corner). The map is based on Koistinen et al. (2001). Red crosses denote occurrences of scapolitised rocks after Frietsch et al. (1997). 


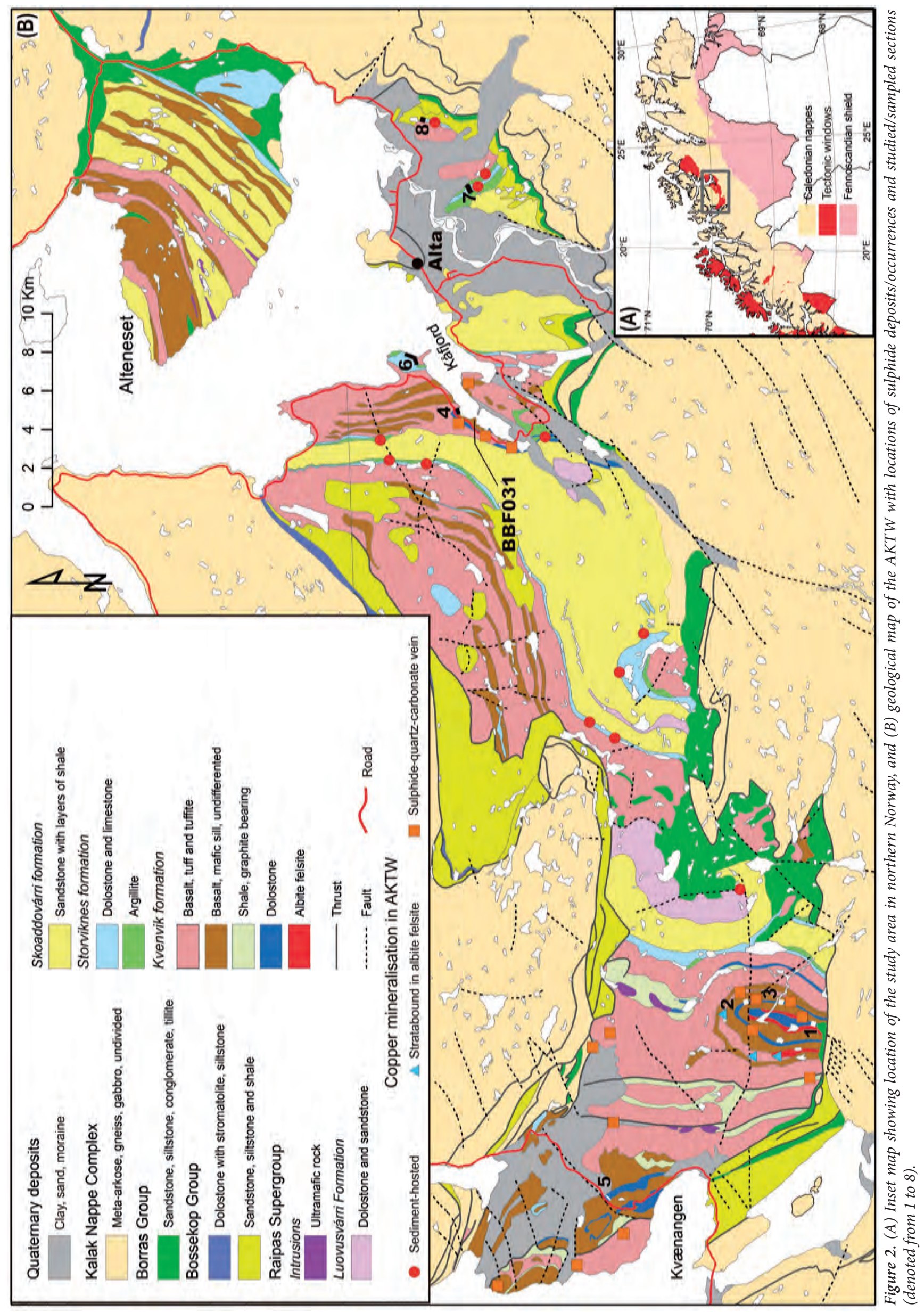




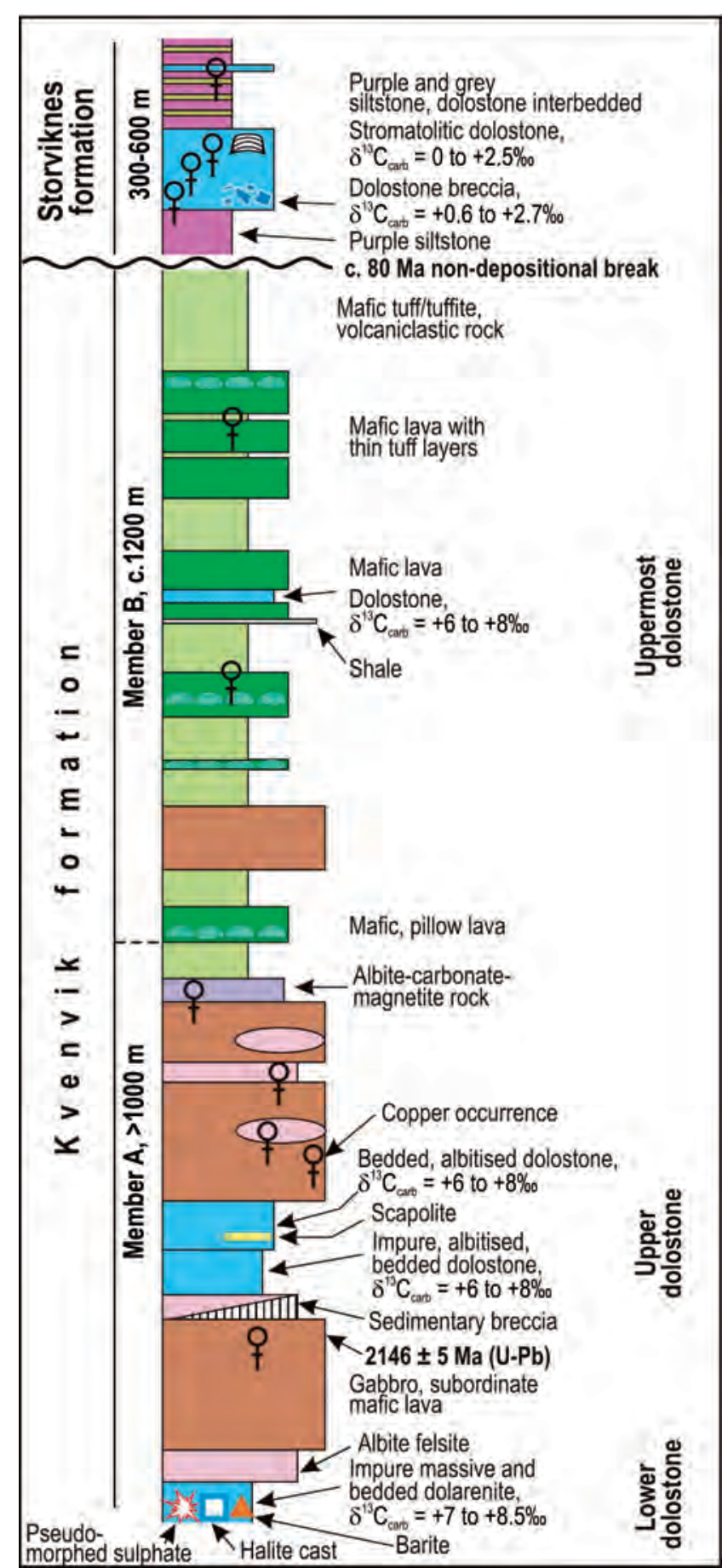

Figure 3. Lithostratigraphic column of the Kvenvik and Storviknes formations occurring in the AKTW. Modified after Vik (1985).

the Cameca IMS 1280 instrument at the NORDSIM laboratory in Stockholm, with a primary oxygen beam of c. $15 \mu \mathrm{m}$ in diameter. Analytical protocols and data reduction follow Whitehouse et al. (1999) and Whitehouse \& Kamber (2005). Analyses were calibrated using the 91500 Geostandard reference zircon (1065 Ma, Wiedenbeck et al., 1995), measured at regular intervals. The analyses are corrected for common $\mathrm{Pb}$ using the ${ }^{204} \mathrm{~Pb}$ signal, if this signal is above background. A TeraWasserburg (inverse) concordia diagram was prepared with the ISOPLOT macro for Microsoft Excel (, 2001).
The weighted average ${ }^{207} \mathrm{~Pb} /{ }^{206} \mathrm{~Pb}$ age of near concordant to concordant analyses is quoted with a 2 sigma error (decay constant uncertainties propagated; systematic uncertainties resulting from interlaboratory experiments not propagated).

\section{Lithology and lithofacies interpretation of studied carbonate units}

All studied carbonate rocks are within the Raipas Supergroup and form parts of the Kvenvik and Storviknes formations. In each formation, most of the carbonate units have been sampled in at least two separate sections located in geographically different areas.

\section{The Kvenvik formation, Member A}

There are two major carbonate units in Member A of the Kvenvik greenstone formation. The lowermost unit, the Lower dolostone hereafter, has been studied and sampled in the Bergmark area (Section 1; for location, see Fig. 2). Carbonate rocks representing the stratigraphically highest carbonate unit, the Upper dolostone hereafter, have also been studied and sampled in the Bergmark area (Sections 2-3) and along the western coast of Kåfjord (Section 4).

\section{The Bergmark area, Section 1}

The geology of the Bergmark area has been comprehensively studied by Vik (1985). In the following sections, we provide new sedimentological observations together with a review of previously published material.

Section 1 records the Lower dolostone unit. It is the lowermost unit in the Kvenvik formation (Fig. 3), and is only partially exposed in the core of a large anticline (Fig. 2). The base of the unit as well as its true thickness remain unknown. The exposed part of the Lower dolostone is less than $100 \mathrm{~m}$ thick and is composed of two different lithofacies.

The first lithofacies forms the lower part of the unit. It is typified by red, structureless, massive, dolorudites and dolostones (Fig. 4A, B) with rare, up to $1 \mathrm{~m}$-thick intervals composed of calcitic rocks. All lithologies are recrystallised and intensively silicified. In places, dolostones contain sheets and rafts of green shales, and thin, intensely disrupted/dismembered mudstone layers (Fig. 4C). Several intervals contain clusters of centimetresize quartz aggregates. Some have cube-shaped crystals (Fig. 4D), whereas others exhibit a spherical and wedge-shaped morphology (Fig. 4E). Red, massive and stuctureless dolostones are composed of cloudy dolospar (Fig. 4E). 

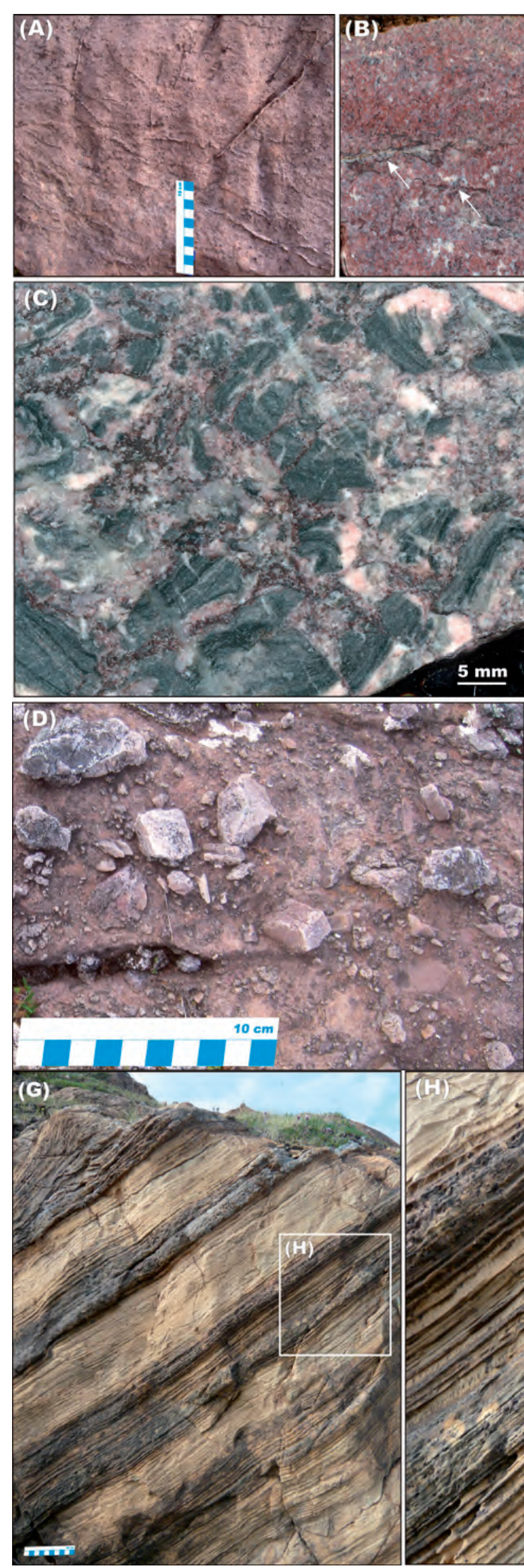

$1 \mathrm{~cm}$

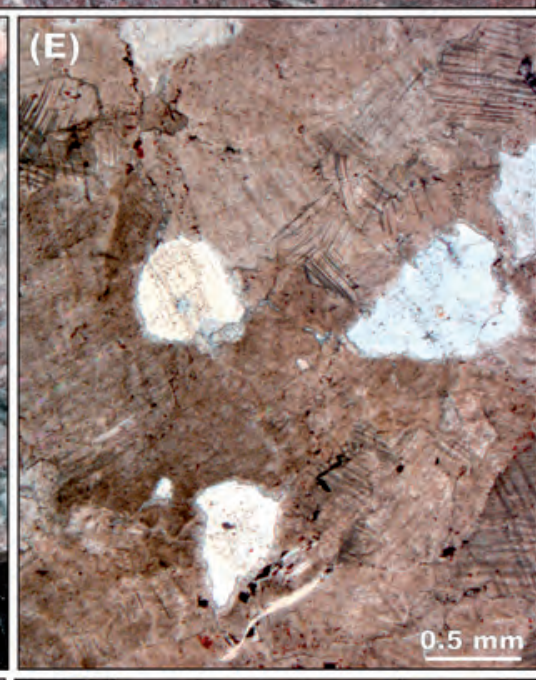

\section{(ain}

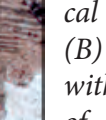

with dismembered layers of dark-brown mudstone (arrowed) (sample JS1324). (C) Dolostone containing sheets and rafts of dark-green shale originating from intensely disrupted/dismembered mudstone layers (sample JS1331). (D) Red, structureless dolarenite with abundant cube-shaped, quartz-pseudomorphed crystals of apparent halite (sample JS1325). (E) Photomicrograph in planepolarised, transmitted light showing quartz-pseudomorphed crystals of probable Ca-sulphate embedded in a cloudy dolospar matrix (sample JS1325). Lower dolostone (thinly-laminated dolostone lithofacies): (F) Pale-yellow, thinly laminated dolostone (sample JS1326). (G) Rhythmically interbedded, decimetre-thick, silicaterich (grey) and silicate-poor (pale-yellow) dolostone units (sample JS1327). (H) Millimetre-thick lamination in pale-yellow dolostone bed caused by alternation of laminae with a variable ratio of carbonate and noncarbonate components. 

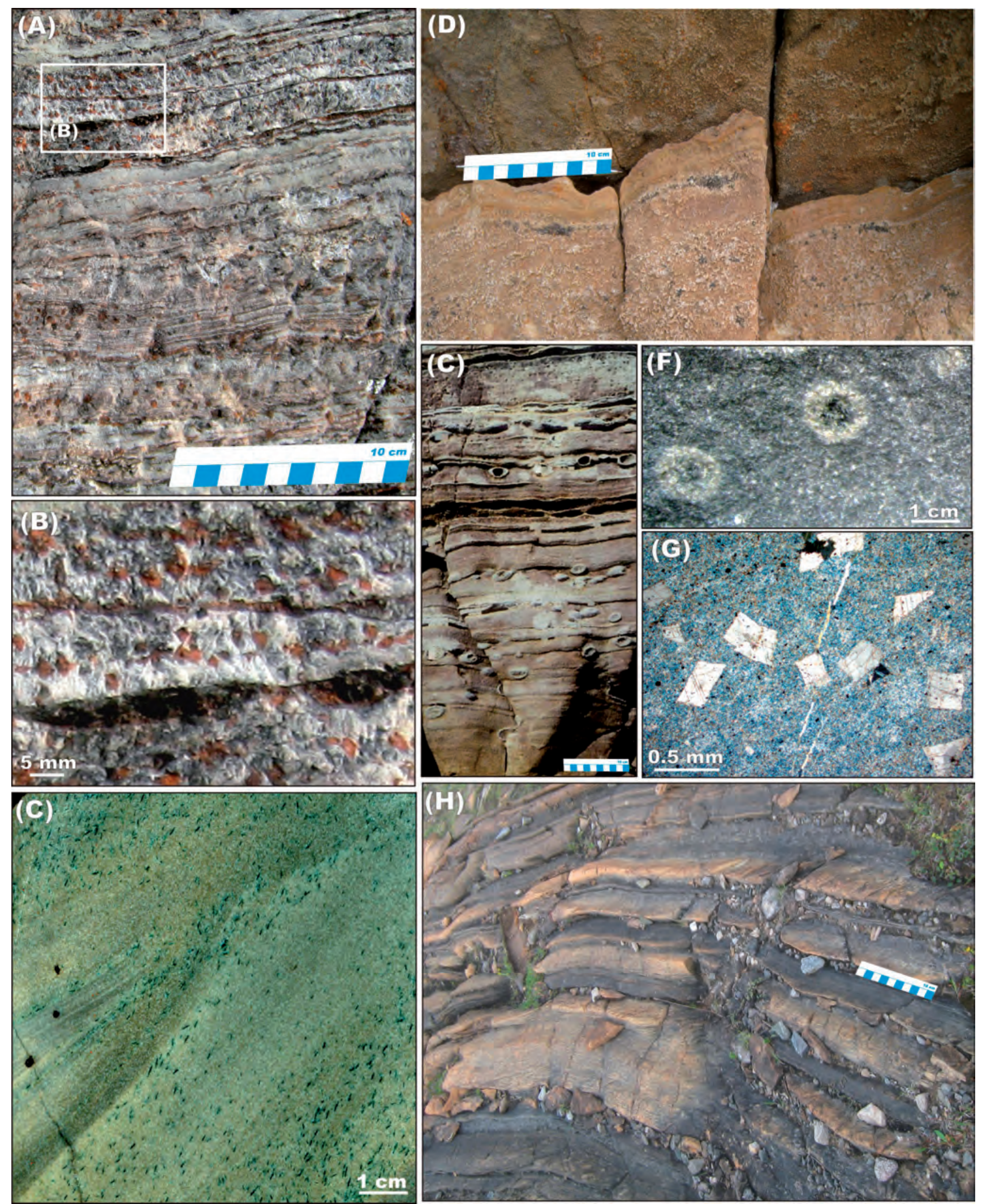

Figure 5. Images of natural outcrops $(A, B, D, E, H, L-O, Q, R)$, polished slabs (F, $I, P, S-U)$ and thin-sections $(G, J, K)$ illustrating the main sedimentological features of carbonate rocks of Member $A$ in the Kvenvik formation studied in Sections 2 and 3 at Bergmark. Section 2, Upper dolostone (impure, laminated, dolostone lithofacies): (A) Pale-grey, laminated, albitised, carbonate-silicate rock with abundant porphyroblastic dolomite (sample JS1312). (B) Enlarged image showing dolomite rhombs. (C) Trough cross-bedding in albitised dolarenite (sample JS1315). (D) A bed of massive dolarenite showing pale-brown colour on weathered surface (sample JS1313). (E) Carbonate-silicate rock with abundant nodules composed of albite-rich rims and dolomite-rich cores; modified after Vik (1985). (F) Impure, albitised dolostone with nodules showing dolomite-rich rims whereas the cores have a compositional similarity with the host rock (sample JS1314). (G) Albite felsites composed of an albite-biotite granular mass with porphyroblastic dolomite rhombs (sample JS1311). Section 2, Upper dolostone (bedded dolostone lithofacies): (H) Rhythmically interbedded dolostone-dolomarl-shale cycles typifying a turbiditic Bouma sequence (sample JS1321). 


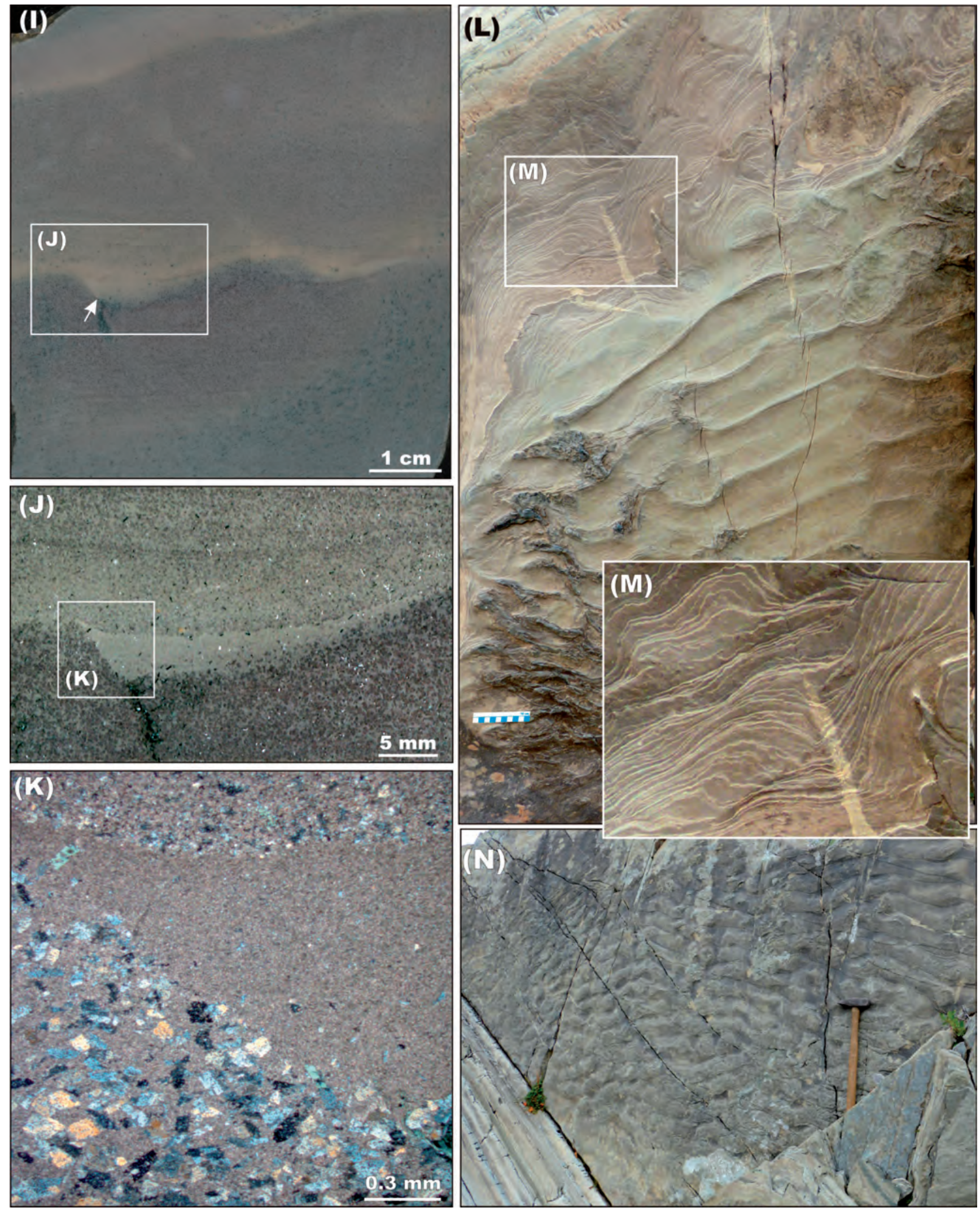

Figure 5 (continued). (I) Variegated dolarenite showing ripples and a small-scale erosional channel (arrowed) (sample JS1319). (J) Enlarged image of the erosional channel showing compositional differences between dark-grey, massive, intensively dolomitised dolarenite and palegrey, bedded dolarenite filling the erosional channel (sample JS1319). (K) Photomicrograph of the erosional channel in polarised, transmitted light. Note that the channel is filled with fine-grained dolarenite which is devoid of albite, whereas dolarenite layers situated above and below the channel contain abundant albite porphyroblasts though differing in size (sample JS1319). Section 3, Upper dolostone (impure, laminated, dolostone lithofacies): (L) Thinly laminated quartz sandstone with asymmetrical ripples replaced by albite to form albite felsites. (M) Enlarged image detailing thin lamination preserved in the pervasively albitised quartz sandstone. (N) Ripple-marked quartz sandstone altered into albite felsites; hammer head for scale is $15 \mathrm{~cm}$. 

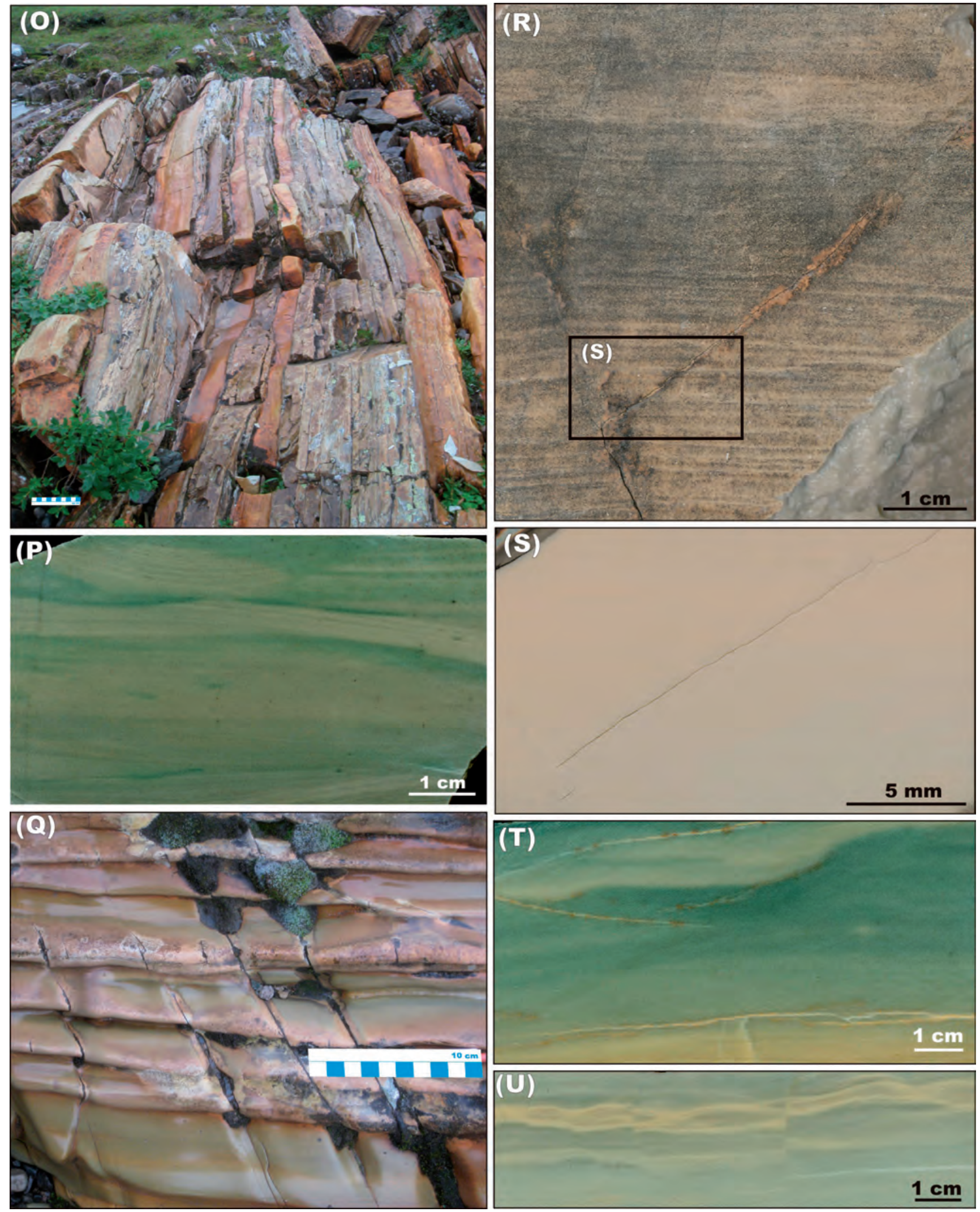

Figure 5 (continued). (O) Thin intervals of homogeneous dolostones (pale-brown) embedded in thin-bedded silicate-rich varieties (sample JS1336). (P) Dolarenite exhibiting small-scale erosional channels and small-scale trough cross-beds (sample JS1334). Section 3, Upper dolostone (bedded dolostone lithofacies): (Q) Rhythmically interbedded dolostone and sandy/shaly dolostone couplets (sample JS1341). (R) Fine, parallel lamination seen on weathered surface of a dolostone bed (sample JS1337). (S) Parallel-laminated dolostone appears massive on the polished surface (sample JS1337). (T) Small-scale erosional channel in pale-green dolostone (sample JS1339). (U) Dolostone showing flaser bedding (sample JS1342). 
Section 4 in Fig. 2

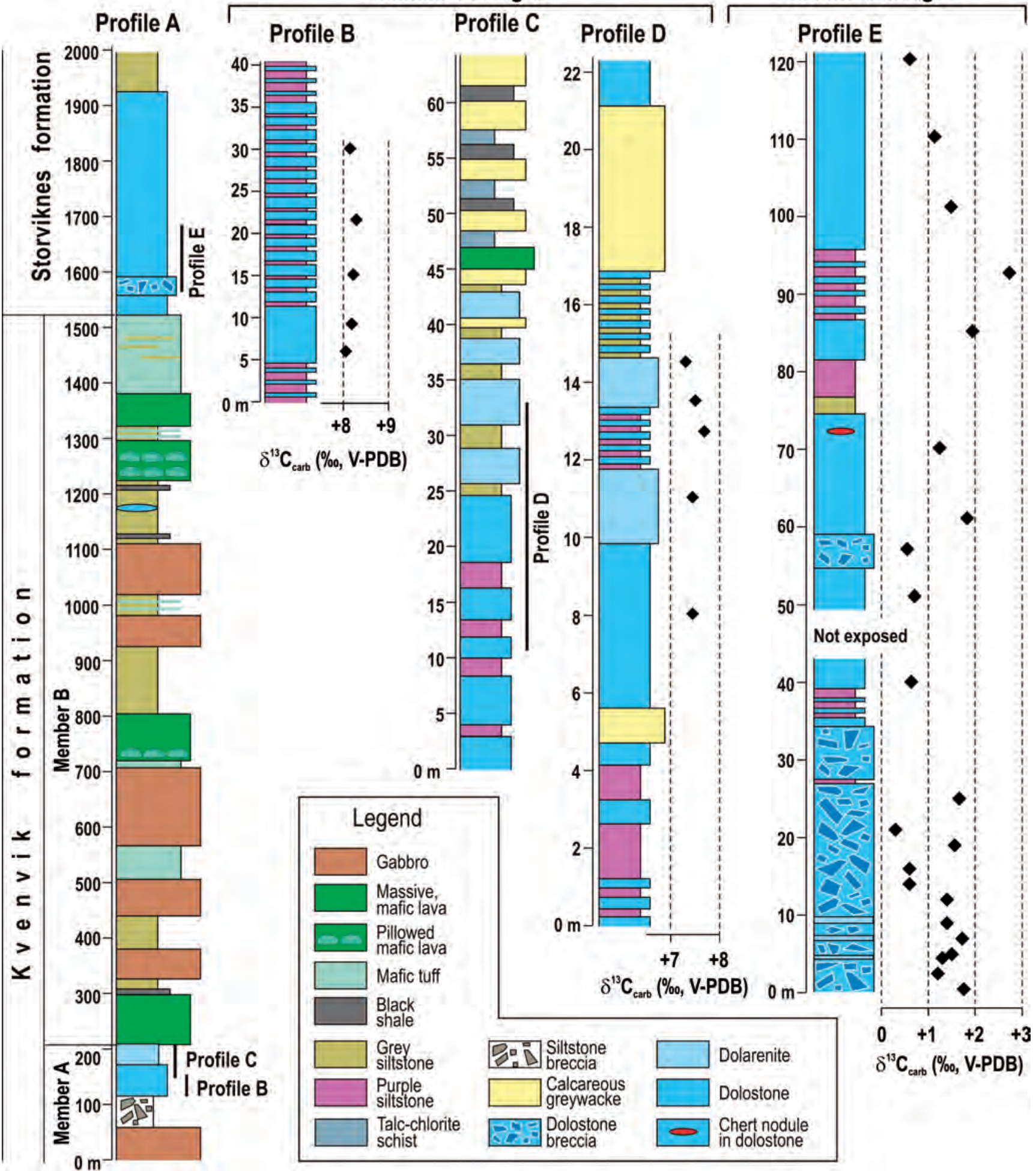

Figure 6. Lithostratigraphic columns and C-isotope profiles of sections studied in the Kåfjord area.

Lithofacies interpretation. Vik (1985) assigned this lithofacies to tidal channel deposits developed on a tidal flat. However, the lack of cross-bedding is in conflict with the above interpretation. Moreover, cube-shaped crystals of quartz resemble pseudomorphed halite crystals (Fig. $4 \mathrm{D})$, whereas quartz aggregates with the spherical and wedge-shaped morphology are interpreted as crystals and aggregates of Ca-sulphates (Fig. 4E). This, together with the general lack of bedding/layering, widespread red beds and intensely disrupted layers (desiccated?) are all indicative of deposition in an oxic, coastal sabkha environment.

The second lithofacies comprises the upper part of the 
Lower dolostone. The contact with red, massive dolostones is not exposed. The lithofacies is typified by pale-yellow, thinly laminated dolostones (Fig. 4F). Some intervals exhibit a decimetre-thick, rhythmic bedding of silicaterich and silicate-poor dolostone units (Fig. 4G). Similarly, the millimetre-thick lamination is also expressed by a variable ratio of carbonate and non-carbonate components (Fig. 4H). The laminated dolostones contain numerous, $0.1-1.0 \mathrm{~m}$-thick, fine-grained, thinly laminated, albite-rich beds locally termed albite felsites. They are concordant with the host sedimentary rocks (Vik, 1985). The laminated dolostones are impure and contain mica, rounded and angular quartz grains and abundant albite appearing as a late growth rather than as clastic grains. Rare beds composed of sparitic calcite with minor clastic quartz, albite porphyroblasts and small fragments of quartz sandstone are present.

Lithofacies interpretation. Vik (1985) interpreted the laminated dolostone lithofacies as intertidal deposits accreted on a carbonate platform. Sedimentological features briefly described above corroborate the intertidal depositional setting; however, a high degree of dolostone impurity is more consistent with a carbonate shelf significantly affected by siliciclastic input. Vik (1985) noted that the origin of the albite felsites remains enigmatic.

\section{The Bergmark area, Section 2}

Section 2 records the Upper dolostone unit. It is separated from the Lower dolostone by a c. $50 \mathrm{~m}$-thick gabbro sill fringed at its top by c. $10 \mathrm{~m}$-thick layer of albite felsite (Fig. 3). The Upper dolostone was sampled in the eastern limb of a syncline close to its hinge (Fig. 2) where the exposed part of the Upper dolostone is over $70 \mathrm{~m}$ thick. Vik (1985) recognised two main lithofacies in the Upper dolostone: (i) an impure, laminated dolostone (c. $35 \mathrm{~m}$ thick), forming the base of the unit; and (ii) a bedded dolostone (c. $40 \mathrm{~m}$ thick) representing the upper part of the succession.

The impure, laminated dolostone lithofacies consists of pale-grey rocks with millimetre-scale lamination (Fig. 5A) and abundant porphyroblastic dolomite rhombs (Fig. 5B). Vik (1985) reported that the parallel lamination is caused by a gradual transition between two mineral parageneses: $(i)$ dolomite+albite+biotite \pm (quar $\mathrm{tz}$, calcite, chlorite); and (ii) quartz+dolomite+biotite \pm( calcite, chlorite). Planar and trough cross-bedding (Fig. 5C), and convoluted lamination (Vik, 1985) have also been observed. Some sandy beds show nicely preserved ripple marks (Vik, 1985). The microfabric of the rock is defined by a microcrystalline, granular texture. The impure, laminated dolostones are commonly albitised and may contain numerous thin beds of albite felsites. Some intervals incorporate decimetre-thick beds of a pale-brown, massive dolarenite (Fig. 5D). A c. 3 m-thick interval, occurring in the middle part of the section, contains numerous carbonate-silicate concretions. One type of nodule has an albite-rich rim and dolomite-rich core (Fig. 5E), whereas another has a dolomite-rich rim with a core showing no mineralogical differences with respect to the host rock (Fig. 5F). The albite felsites are composed of albite and biotite intergrown into a microcrystalline, granular mass with porphyroblastic dolomite rhombs (Fig. 5G). The rocks have a millimetrescale parallel and wavy lamination.

The bedded dolostone lithofacies is typified by centimetreto decimetre-thick cycles composed of dolostonedolomarl-shale triplets resembling a turbiditic Bouma A-B sequence (Fig. 5H). Thicker and more homogeneous dolostone beds are also present. The uppermost part of the section contains dolostone beds alternating with siltstones overlain by limestones and graphitic schists (Vik, 1985). The dolostones contain numerous beds of albite felsite. The bedded dolostone lithofacies is characterised by weak, parallel bedding and graded bedding. Current ripples, small-scale erosional troughs and a flat-laminated, probable stromatolitic structure are other features of this lithofacies (Vik, 1985).

The bedded dolostones are composed of dolomite and biotite intergrown into a microcrystalline, granular mass containing abundant porphyroblasts of albite. In some beds, the density of porphyroblasts and their size are controlled by primary sedimentological features such as lamination and channelling (Fig. 5I-K). This suggests that the distribution and size of the porphyroblasts were apparently inherited from those of original clastic grains during albitisation. Vik (1985) also reported beds with magnetite impregnations and scapolite porphyroblasts. The beds with scapolite porphyroblasts are $0.5-1 \mathrm{~m}$ thick, and the amount of visually determined scapolite is up to $50 \%$ by volume.

Facies interpretation. Vik (1985) suggested that the two lithofacies of the Upper dolostone represent a continuous sequence of carbonate accumulation. The slope of a carbonate platform was inferred for deposition of the dolostone-shale lithofacies with Bouma cycles, whereas a deeper water setting, distant from the 'carbonate factory', was suggested for accumulation of the impure, laminated dolostone lithofacies. Dolostone beds with probable stromatolitic structures terminating the carbonate-shale sequence were assigned to intertidal algal mat deposits. A source for the non-carbonate components and the high degree of impurity of all carbonate rocks were interpreted by Vik (1985) to relate to a probable synchronous volcanism or redeposition and long transport of volcanic ash material.

\section{The Bergmark area, Section 3}

Section 3 is a river-bed section located in the eastern limb of the syncline, $1.8 \mathrm{~km}$ to the south of Section 2 (Fig. 2). Here, rocks dip steeply to the east implying tectonic inversion of the limb. The two lithofacies documented and sampled in Section 3 are somewhat similar to those described above in Section 2. 

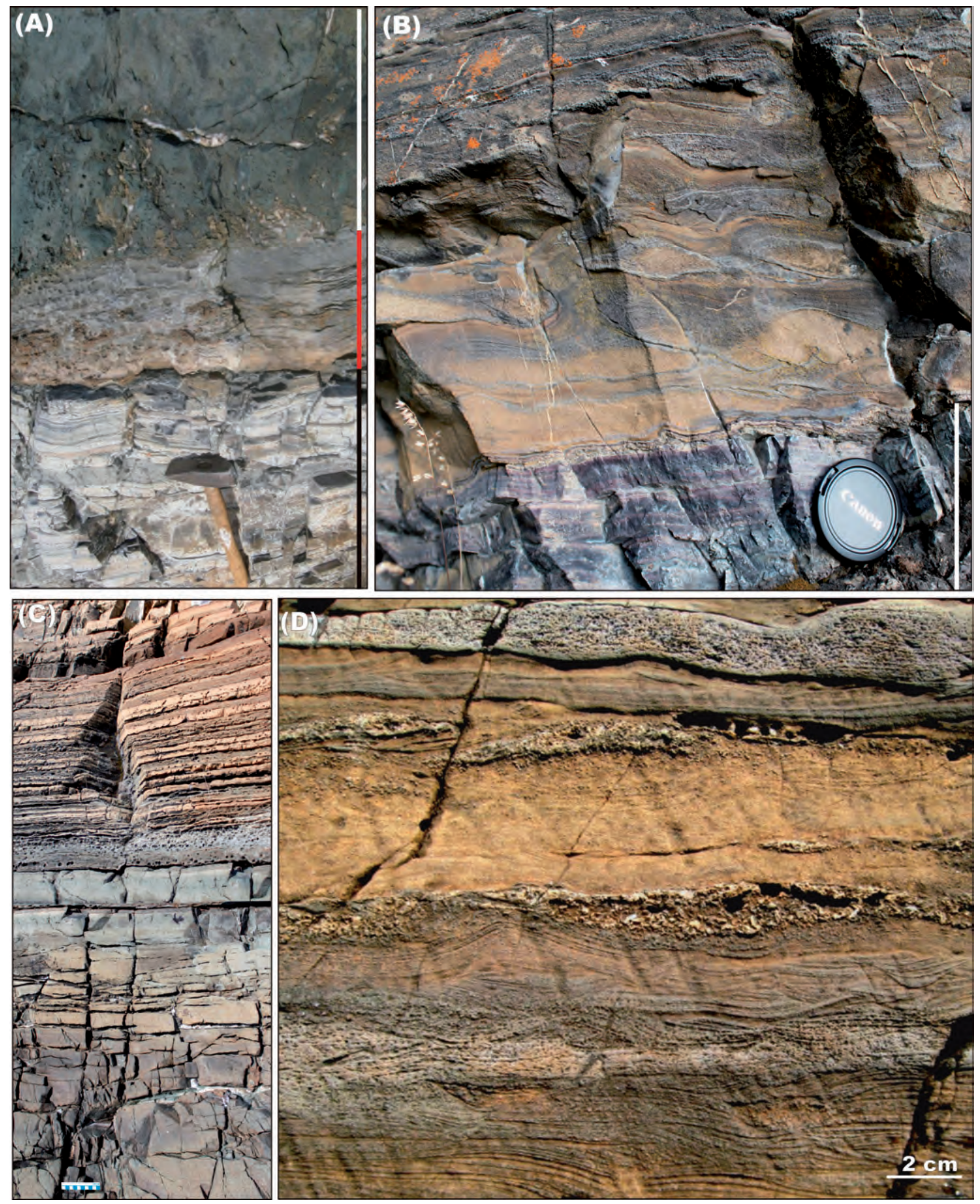

Figure 7. Images of natural outcrops illustrating the main sedimentological features of carbonate rocks and associated lavas and tuffs in Member B of the Kvenvik formation studied in Section 4 at Kåjord. (A) Sandstone-siltstone-shale with lenticular bedding (black bar) and bedded tuff (red bar) overlain by amygdaloidal, tholeiitic basalt (white bar); Hammer head for scale is $15 \mathrm{~cm}$. (B) Purple dolarenite (white bar) overlain by pale-brown, sandy dolarenite with slumped mudstone-siltstone beds; lens cap for scale is $5 \mathrm{~cm}$ in diameter. (C) Massive dolarenite overlain by thickly bedded dolarenite passing upward into thinly bedded varieties with siltstone interlayers. (D, E) Impure, sandy dolostones showing graded bedding, small-scale trough cross-lamination, and abundant, small-scale channelling; lens cap for scale is $5 \mathrm{~cm}$ in diameter. ( $F$ ) Dolarenites (red bars) interbedded with purple siltstone/shale; note that the dolarenites occur as continuous beds, ripples and channel infills, whereas the interbedded siltstones are characterised by low-angle cross-lamination. (G) Variegated siltstone with parallel bedding. (H) Graded bedding in pink sandstone-siltstone. 

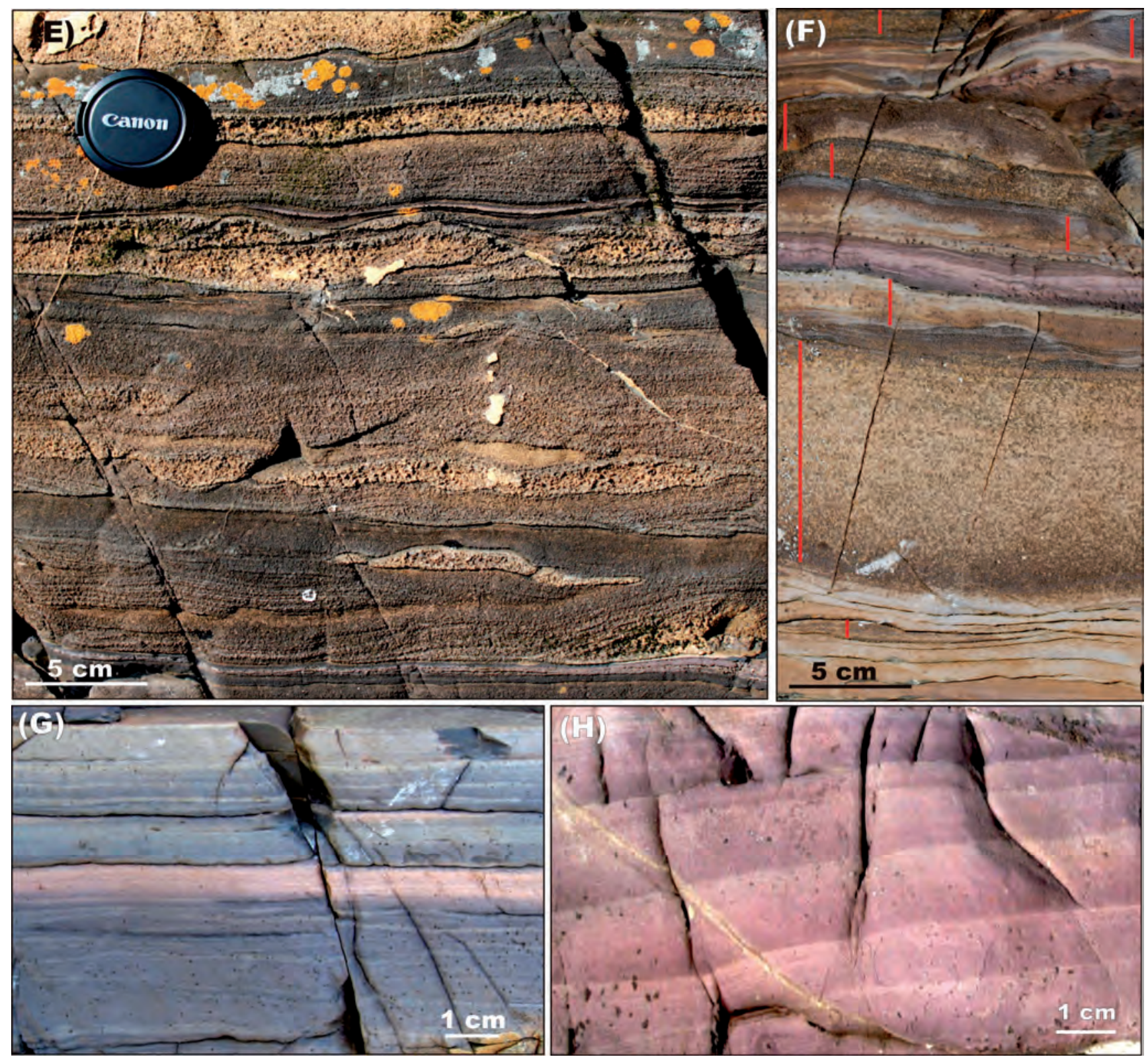

The impure, laminated, dolostone lithofacies rests with a sharp base on albite felsites. The latter show a thin, parallel bedding with some intervals preserving asymmetrical ripples (Fig. 5L-N). The impure, laminated dolostones are pale-grey, beige and pale-green rocks with millimetrescale lamination. This lithofacies contains numerous beds of homogeneous dolostones (5 to $15 \mathrm{~cm}$ thick) embedded into thinly bedded silicate-rich varieties (Fig. 5O). Their primary sedimentological features are defined by numerous small-scale erosional channels and stacks of small-scale, trough cross-beds (Fig. 5P).

The bedded dolostone lithofacies is characterised by rhythmically bedded units composed of $2-10 \mathrm{~cm}$-thick, dolostone-sandy/shaly dolostone couplets (Fig. 5Q). They contain irregularly spaced, thicker beds of dolostones showing a fine, parallel lamination on weathered surfaces (Fig. 5R) with homogeneous, massive fabrics in polished slabs (Fig. 5S). Such dolostone beds contain intervals with small-scale, erosional channels, cross-bedding (Fig. 5T) and flaser bedding (Fig. 5U).

Lithofacies interpretation. The sedimentological features observed in Section 3 suggest depositional settings similar to those inferred for rocks documented in Section 2.

\section{Kåfjord western coast, Section 4}

Section 4 intersects a dolostone unit located in the uppermost part of Member A of the Kvenvik formation. This has been studied on the western coast of Kåfjord (Fig. 6, Profile A). According to Vik (1985), the studied succession represents a time equivalent of the Upper dolostone unit studied in Sections 2 and 3. The sedimentary unit represents a mixed carbonate-siliciclastic succession composed of several carbonate-siltstone cycles of 
variable thicknesses, which pass upward into calcareous greywacke-chlorite schist cycles. The carbonatedominated cycles are separated from the siliciclastic ones by a mafic lava flow (Fig. 7A; Fig. 6, Profile C). The total thickness of the carbonate-siliciclastic succession is close to $100 \mathrm{~m}$; however, it is only partly accessible and its suitability for sampling is limited to Profile D (Fig. 6).

Section 4 is a composite section consisting of two marginally overlapping profiles on the western side of Kåfjord (Fig. 2). The lowermost part of the sampled interval, Profile B hereafter, located on a partially accessible cliff, is underlain by a siltstone breccia which is intruded by a gabbro body (Fig. 6, Profile A). The upper part of Section 4, Profile C hereafter (Fig. 6), was sampled on the Kåford coast. The top of Profile B marginally overlaps with the base of Profile C; however, a strike distance of over several hundred metres between the two prevents their precise correlation.

Profile B represents a succession typified by several centimetre-thick, grey dolarenite/pink mudstone/ siltstone couplets showing lenticular, wavy and flaser bedding. Sampled dolarenite units are either massive or bedded and may show indistinct vertical grading in clast size, whereas the mudstone-siltstone beds are characterised by small-scale, low-angle cross-lamination. One bed displays soft-sediment deformation structures caused by slumping (Fig. 7B).

Profile C starts with the grey dolarenite/pink mudstone/ siltstone succession described above. This is followed by a $1 \mathrm{~m}$-thick bed of grey, thick-bedded greywacke sharply overlain by a c. $12 \mathrm{~m}$-thick unit composed mainly of both thick- and thin-bedded dolarenites with two intervals of thinly interbedded dolostone-siltstone, each 1 to $2 \mathrm{~m}$ thick. The primary textural pattern of the dolarenites varies from massive through thick-bedded to thin-bedded with siltstone interlayers (Fig. 7C). Many intervals show graded bedding, small-scale, trough crosslamination and abundant, small-scale, channelling (Fig. 7D, E). All dolarenite beds are sharp-based. Thick-bedded dolostones display flat top surfaces, whereas the thinbedded varieties with siltstone interbeds show rippled surfaces. Some dolarenite beds retain their thickness over several metres, whereas others occur as ripples or channel infills. Interbedded siltstones are characterised by lowangle cross-lamination, parallel bedding and graded bedding (Fig. 7F-H).

Facies interpretation. The observed sedimentological features of the sampled dolarenite-siliciclastic succession suggest that sedimentation occurred in a carbonate shelf environment transitional from the lower intertidal (massive to thickly bedded dolarenite) to the upper intertidal (interbedded dolarenite-siltstone with lenticular, wavy and flaser bedding) zone.

\section{The Kvenvik formation, Member B}

\section{The Badderen area, Section 5}

The carbonate rocks sampled at Badderen (Fig. 2, Section 5) represent a c. $100 \mathrm{~m}$-thick succession of carbonate rocks with minor shale beds exposed along a road-cut. This sedimentary succession, the Uppermost dolostone hereafter, is sandwiched between two thick piles of mafic lava flows. The carbonate rocks occurring at the base of the unit are composed of microcrystalline dolomite with abundant quartz particles, tremolite needles and biotite porphyroblasts. The rocks display parallel bedding which is visible only on weathered surfaces (Fig. 8A), or show only a faint parallel lamination on polished surfaces (Fig. 8B).

The carbonate rocks of the middle and upper parts of the Uppermost dolostone are composed of microsparitic dolomite and calcite, and contain abundant biotite porphyroblasts, tremolite needles and quartz particles. The rocks preserve parallel bedding and a faint, millimetrescale, low-angle cross lamination (Fig. 8C, D). Associated beds of siliciclastic rock show well-developed parallel bedding expressed by $1-2 \mathrm{~cm}$-thick siltstone layers draped by thinner units of dark-grey mudstone (Fig. 8E).

Thick piles of mafic volcanic rocks underlying and overlying the Uppermost dolostone imply deposition in an active volcanic environment. The overall sedimentological features of both carbonate and siliciclastic rocks suggest deposition in a deep-marine setting, apparently from turbidity currents.

\section{The Storviknes formation}

Three major carbonate units of the Storviknes formation have been sampled in three different locations: (i) at Storvik, Section 6; (ii) at Raipas, Section 7; and (iii) at Borras, Section 8 (Fig. 2). Although these three sections are located in different areas, they represent correlative, supposedly time-equivalent successions (Vik, 1985).

\section{Storvik, Section 6}

At Storvik, the carbonate-dominated succession, the Dolostone member hereafter, rests on mafic tuffs of the Kvenvik formation and is overlain by grey siltstones. The reported total thickness of the member may reach $200 \mathrm{~m}$ (Fig. 6), but it is not possible to make accurate measurements. Section 6 represents only the lower part of the Dolostone member (Fig. 6, Profile E) where the dominant rocks are bedded dolostone, syndepositional breccia and purple siltstone. The bedded dolostone and purple siltstone are present throughout the section whereas the dolostone breccia has only a localised development. The sedimentary succession is gently folded and all lithologies are variably recrystallised.

The bedded dolostone (Fig. 9A) preserves a large array of primary sedimentological features including parallel 


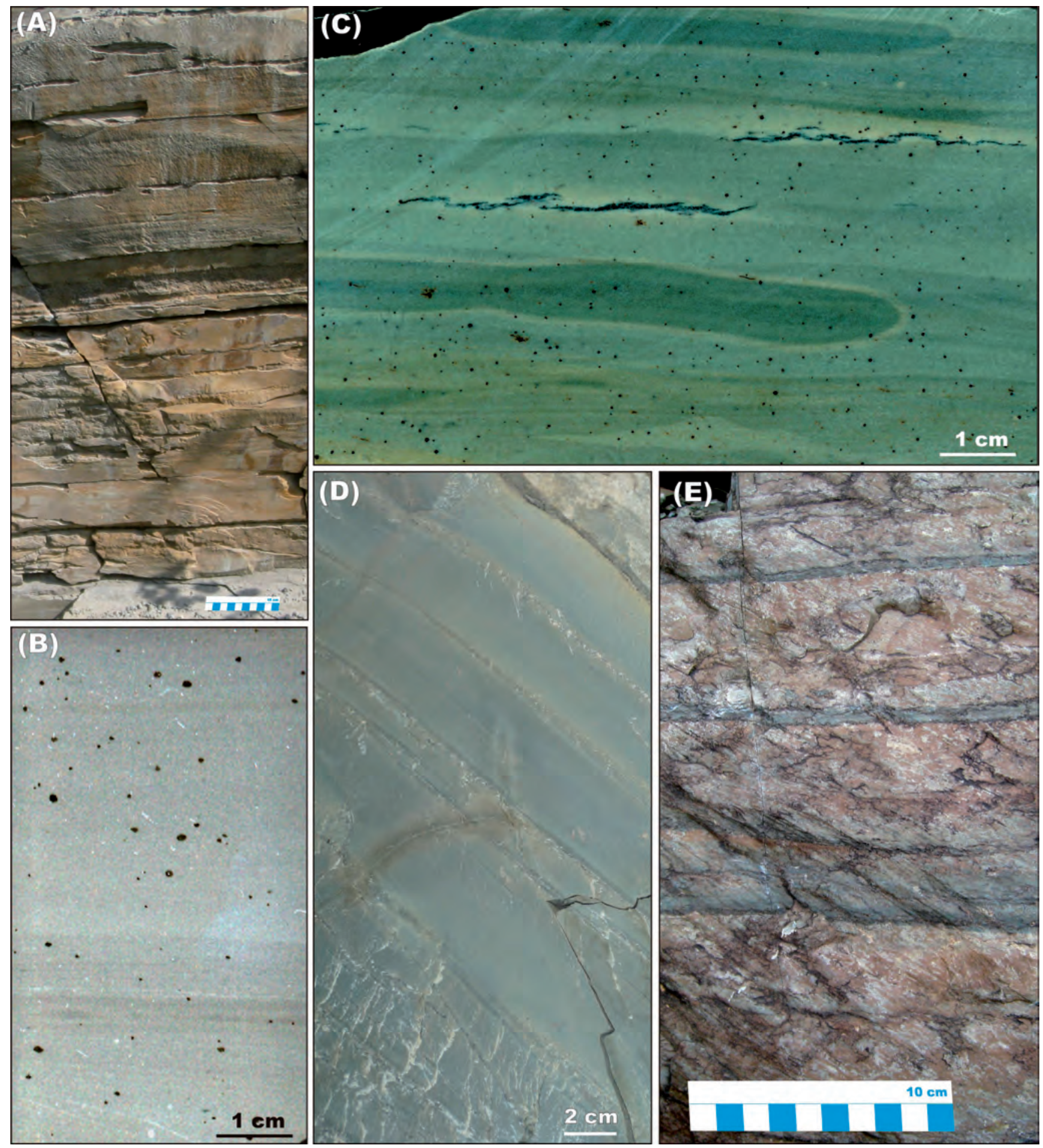

Figure 8. Images of natural outcrops $(A, D, E)$ and polished slabs $(B, C)$ illustrating the main sedimentological features of carbonate rocks of Member B in the Kvenvik formation studied in Section 5 at Badderen. (A) Parallel bedding in microcrystalline dolostone visible on a weathered surface (sample JS1310). (B) A polished slab of microcrystalline dolostone showing faint bedding (sample JS1308). (C) Green, microcrystalline dolostone characterised by faint, millimetre-scale, low-angle cross-lamination and a 'roll structure' caused by bedding-parallel infiltration of a post-depositional fluid (sample JS1306). (D) Pale-grey, microcrystalline dolostone with thick, parallel bedding (sample JS1303). (E) Brownishgrey, siltstone beds draped by dark-grey mudstone.

and wavy lamination, flaser bedding, silicified flatlaminated stromatolites, ripple marks and chert nodules. Several dolostone beds reveal a clastic texture and are composed of sand-size particles of dolostone, quartz and red jasper, hence representing a dolarenite. Interbeds of purple siltstone are 0.5 to $5 \mathrm{~cm}$ thick, partially silicified, and commonly exhibit wavy and low-angle cross lamination. 

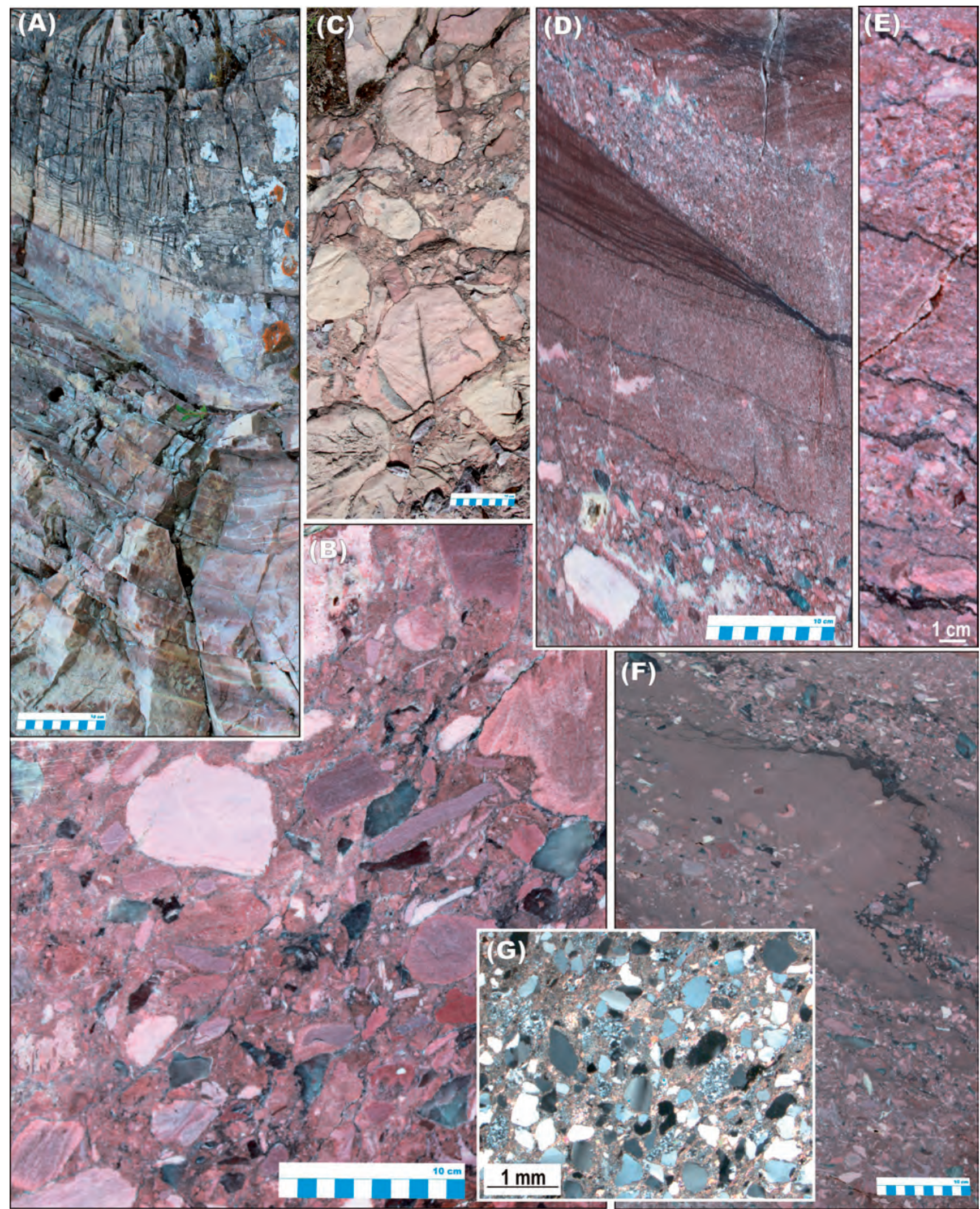

Figure 9. Images of natural outcrops $(A-F)$ and a thin-section $(G)$ illustrating the main sedimentological features of carbonate rocks of the Storviknes formation studied in Section 6 at Storvik (Profile E in Fig. 6). (A) Bedded dolostone forming the bulk of the Storviknes formation in the Storvik area. (B) Clast-supported breccias composed of angular, unsorted fragments of dolostone (pink, brown and white) and chert (red, black and grey). (C) Matrix-supported breccias composed of blocks of crystalline dolostone. (D) Carbonate breccias-greywacke lithofacies represented by two sets of trough cross-beds. Note upward grading from a breccia through a grit-sand into a silt-mud. (E) Breccia beds each separated by thin, black, hematite-rich, mud drapes. (F) A slump structure in a sand bed sandwiched between two beds of breccias. (G) Photomicrograph in polarised, transmitted light showing sandstone composed of rounded grains of quartz and chert embedded in a quartz-sericite matrix. 
A large, c. $35 \mathrm{~m}$-thick, lensoidal body of syndepositional breccias (Fig. 9B-G) occurs in the lower part of the sampled succession. A quarry with near-vertical smooth walls cut through the breccias provides an excellent exposure even though the basal contact of the lens is not exposed. Two main lithofacies are recognised in the breccia body: (i) carbonate debris lithofacies; and (ii) carbonate breccia lithofacies. The former is $c .2 \mathrm{~m}$ thick and forms the base of the breccia body. This lithofacies is composed of angular, unsorted blocks and fragments of two rock types. The majority of the clasts are pink, brown and white, crystalline, massive dolostones. Some dolostone clasts show pink rims (Fig. 9B). Clasts of red, black and grey cherts are less abundant. The clasts range in size from less than $1 \mathrm{~cm}$ to $25 \mathrm{~cm}$ (Fig. 9B, C). Although the majority of clasts appear to be sub-rounded, some of the fragments are angular. In general, the carbonate debris is clast-supported and poorly sorted (Fig. 9B, C).

The carbonate breccia lithofacies is represented by numerous sets of decimetre-thick, trough cross-beds. Many individual beds show breccias grading upwards into a grit-sand and then into a silty mud (Fig. 9D). Where beds do not show grading they are separated by thin, black, hematite-rich, mud drapes (Fig. 9E). Several beds display soft-sediment deformation structures associated with slumping (Fig. 9F). The clast composition in the breccias and gritstones remains unchanged vertically and laterally. These are mainly dolostones with minor cherts. However, sandstone and siltstone members in all cross-beds are largely composed of rounded grains of quartz and chert supported by a quartz-sericite matrix (Fig. 9G).

Facies interpretation. Primary sedimentary structures and textures preserved in the dolostones are consistent with their accumulation on a carbonate shelf/platform. The carbonate breccias can be confidently assigned to a channel deposit. Two distinctly different sources of clastic material (dolostone intraclasts and quartz sand), a low degree of roundness and the unsorted nature of dolostone intraclasts can be reconciled with a depositional model involving the formation of a high-relief, shore-to-basin, fault scarp followed by the development of a channel, with subsequent, long-distance transport of quartz sand from the continent-basin margin, which was redeposited together with locally derived dolostone intraclasts on the carbonate shelf/platform. The red colour of the dolostones and shales suggests oxic environments.

\section{Raipas, Section 7}

At Raipas, the Storviknes formation has a thickness of over $500 \mathrm{~m}$. The formation is composed of purple and grey shales with a c. $200 \mathrm{~m}$-thick unit of dolostones (the Dolostone member) in the middle (Fig. 10). The studied and sampled part of the formation (Section 7) represents a $100 \mathrm{~m}$-thick upper part of the Dolostone member. It includes purple siltstone lithofacies and three carbonate lithofacies: ( $i$ ) a layered dolostone; (ii) a massive dolostone; and (iii) a stromatolitic dolostone. All rocks are variably recrystallised.

The layered dolostone is a dominant carbonate lithofacies occurring as a series of planar beds $2-15 \mathrm{~cm}$ thick. Individual beds are separated by thin layers of purple and grey shales (Fig. 11A). The layered dolostones display a planar, gently buckled and wrinkled lamination resembling that observed in flat-laminated algal mats (e.g., Demicco \& Hardie, 1994). The shale interlayers are intensely silicified (Fig. 11B) and preserve abundant ripples. The overall structural pattern of the bedded dolostone lithofacies is suggestive of stromatolitic biostromes.

The massive dolostone lithofacies occurs as several cupola-like bodies within the layered dolostones. The cupola-like bodies are sharp-based and separated from the layered varieties by thin beds of purple and grey shales with ripple marks. The upper contact is equally sharp but may lack the shale intercalations (Fig. 11B). The massive appearance, lack of lamination and clotted fabrics of this lithofacies superficially resemble those commonly observed in thrombolitic bioherms (cf., Aitken, 1967).

The stromatolitic dolostone lithofacies occurs as columnar and domal stromatolites forming biostromes. Large columns of tightly packed stromatolitic columns with poorly preserved fabrics are separated from each other by intensely silicified shales (Fig. 11C). The biostromes are 1 to $2 \mathrm{~m}$ thick and show a gradual vertical replacement by the layered dolostone lithofacies.

The purple and grey shale lithofacies associated with the dolostone lithofacies occurs as lenses (ripples) and thin discontinuous layers and beds with a maximum thickness of $50 \mathrm{~cm}$ (Fig. 11D). The shale units have sharp contacts with the host dolostones and are characterised by a combination of planar parallel lamination, wavy and lowangle cross-lamination.

Facies interpretation. Vik (1985) suggested that deposition of the carbonate lithofacies in the Raipas area occurred in intertidal settings. Our observations are in accord with this previous interpretation.

\section{Borras, Section 8}

The Upper dolostone at Borras is only $25 \mathrm{~m}$ thick. As reported by Vik (1985), the unit is generally composed of layered and massive, crystalline dolostones with siltstone breccias at the base. The area is poorly exposed; consequently, samples obtained in Section 8 represent only two separate outcrops and actually comprise crystalline limestones. 
(A)

(B)

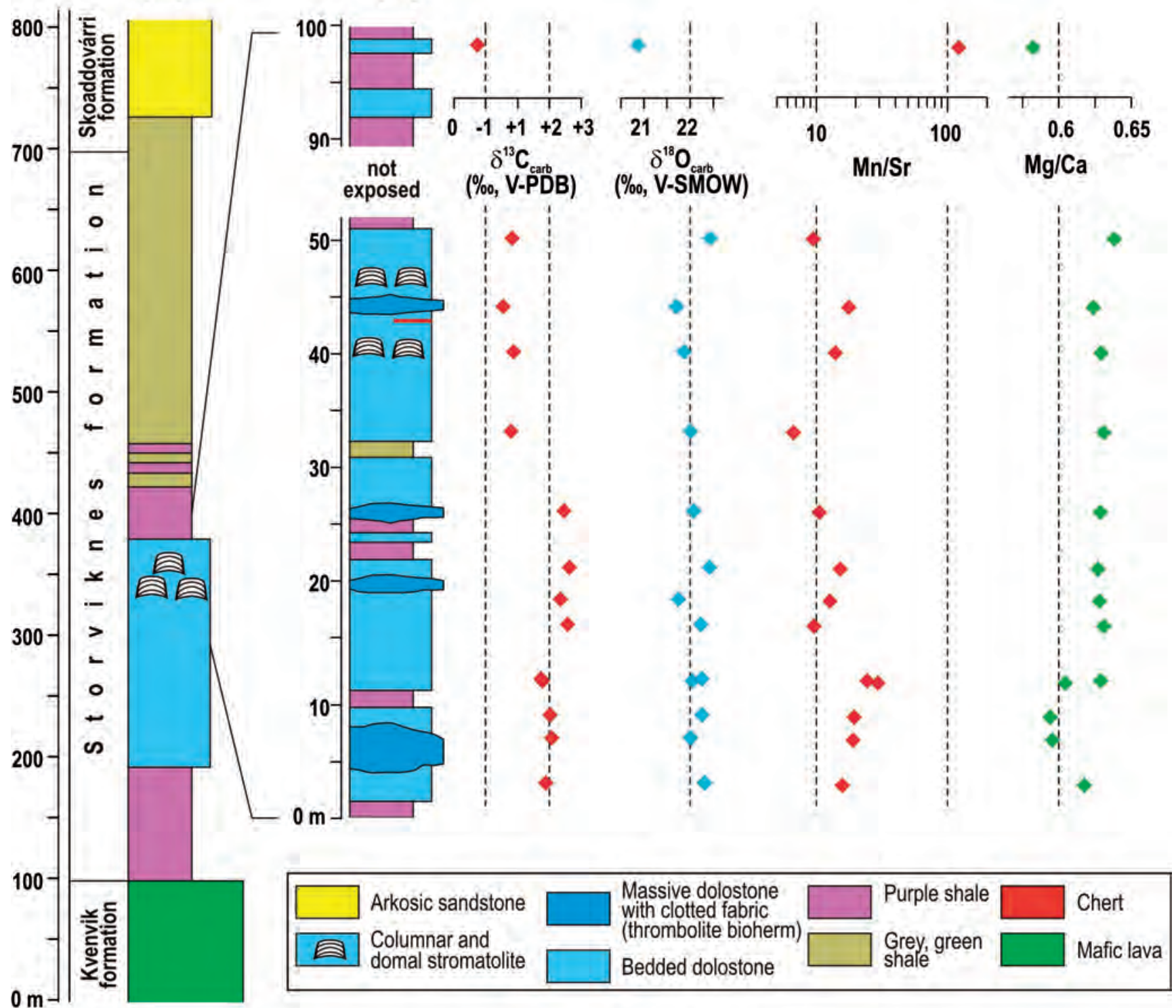

Figure 10. (A) Lithostratigraphic column of the Storviknes formation. (B) Lithological column detailing the sampled portion of the Storviknes formation combined with stratigraphic variations of $\mathrm{Mn} / \mathrm{Sr}, \mathrm{Mg} / \mathrm{Ca}, \mathrm{C}$ - and O-isotopic ratios.

\section{Radiometrically dated igneous rock from the Kvenvik formation at Kåfjord}

In the AKTW, all igneous rocks occur exclusively in the Kvenvik formation (Fig. 3). These are mainly mafic lavas and mafic tuffs as well as intrusive gabbro-dolerite sills and ultramafic bodies. Most of the gabbro bodies are intruded into the lower part of the formation, whereas mafic lavas are abundant in its upper part. The upper part of the formation studied in detail by Bergh \& Torske (1988) contains massive, amygdaloidal and pillowed lavas, pillow breccias and hyaloclastic rocks (Fig. 12A). Volcaniclastic facies are represented by ash, accretionary lapilli tuff and tuff beds, and volcaniclastic rocks (Fig. 12B). The volcanic rocks are intruded by sills of gabbro (Fig. 12C). Bergh \& Torske (1988) classified the Kvenvik volcanic rock association as a MORB-type, tholeiitic basalt. They demonstrated that the lavas and volcaniclastic rocks were deposited in cyclically repeated couplets whose deposition was assigned to a continental rift setting in shallow-water to subaerial environments (Bergh \& Torske, 1988).

Mineralogically, all newly obtained and analysed samples are actinolitised and exhibit a variable degree of saussuritisation and albitisation of primary plagioclase, resulting in a high $\mathrm{Na}_{2} \mathrm{O}$ content observed in some of the samples (BBF -031, JS1411; Table 1). The albitised samples also show enrichment in Fe. Chemically, all analysed magmatic rock samples are tholeiitic basalts (Fig. 13A) with moderate $\mathrm{MgO}, \mathrm{TiO}_{2}, \mathrm{Ni}$ and $\mathrm{Cr}$ contents 
(Tables $1 \& 2$ ). On a Ti-Zr-Y discrimination diagram, all analysed samples plot as 'MORB', transitional to 'withinplate' and 'island-arc' tholeiites, thus providing no unique solution (Fig. 13B). On a chondrite-normalised rareearth element (REE) diagram, two gabbro samples show a positively sloped pattern suggesting a depleted mantle source (Fig. 13C). Other samples exhibit a negatively sloped pattern, hence enrichment in light REEs. This group also includes a dated gabbro collected in a roadcut along the western shore of Kåfjord. The geochemical similarity between lavas and the dated gabbro suggests that they originated from the same parental magma. The positive Eu anomaly visible in the REE pattern of the dated gabbro is consistent with its plagioclase-rich nature and plagioclase accumulation. The overall enrichment in light REEs in both lavas and gabbro could arise either from fractional crystallisation, a small degree of partial melting or crustal contamination.

The radiometric $\mathrm{U}-\mathrm{Pb}$ age determination on zircon was conducted on a thick gabbro body hosting the historical Kåford copper mine and exposed on the western side of Kåfjord (Figs. 2 \& 3). Here, a large road-cut exposure exhibits a leucocratic, coarse-grained gabbro showing an unfoliated ophitic texture (Fig. 12C). Plagioclase laths, commonly $1 \mathrm{~cm}$ long, are embedded in a coarsegrained interstitial amphibole matrix. The latter shows a significant alteration. Mafic minerals are partially replaced by calcite, epidote and chlorite. The rock contains accessory chalcopyrite and magnetite.
The sample collected for zircon separation and age determination represents a homogeneous gabbro, though containing a few calcite-chalcopyrite veinlets. Interestingly, Bergh \& Torske (1988, their fig. 3 on p. 230) mapped this gabbro as a "coarse-grained, massive (mafic) lava".

\section{$\mathrm{U}-\mathrm{Pb}$ radiometric age of the gabbro and coeval mafic lavas of the Kvenvik formation}

With $100 \mathrm{ppm}$ zirconium, the gabbro sample collected on the western side of Kåford (BBF -031) contains prismatic to stubby zircon crystals up to $200 \mu \mathrm{m}$ long. All of the twenty-four non-metamict zircon crystals extracted show a consistent morphology and are characterised by a weak, planar oscillatory zoning and absence of a core-rim texture. Some crystals have cracks filled with luminescent zircon. Thirteen $\mathrm{U}-\mathrm{Th}-\mathrm{Pb}$ analyses of ten oscillatoryzoned zircon crystals are concordant to near-concordant (concordance $>96 \%$ ) and yield a well-clustered ${ }^{207} \mathrm{~Pb} /{ }^{206} \mathrm{~Pb}$ weighted average age of $2146 \pm 5 \mathrm{Ma}$ (Fig. 14, Table 3). Two additional analyses were probably affected by some radiogenic $\mathrm{Pb}$ loss and therefore are not included in the average calculation. The oscillatory zoning and $\mathrm{Th} / \mathrm{U}$ ratio in the range between 0.3 and 1.5 are characteristic of magmatic zircon, and therefore the age of $2146 \pm 5 \mathrm{Ma}$ is interpreted as the magmatic crystallisation age of the gabbro body and the age of the co-magmatic lavas higher in the stratigraphy of the Kvenvik formation (Member B).

Table 1. Content of major elements and loss on ignition in igneous rocks of the Kvenvik formation based on XRF analyses.

\begin{tabular}{|c|c|c|c|c|c|c|c|c|c|c|c|c|}
\hline Sample \# & $\mathrm{SiO}_{2}$ & $\mathrm{Al}_{2} \mathrm{O}_{3}$ & $\mathrm{Fe}_{2} \mathrm{O}_{3}$ & $\mathrm{TiO}_{2}$ & $\mathrm{MgO}$ & $\begin{array}{l}\mathrm{CaO} \\
\mathrm{wt} \%\end{array}$ & $\mathrm{Na}_{2} \mathrm{O}$ & $\mathrm{K}_{2} \mathrm{O}$ & $\mathrm{MnO}$ & $\mathrm{P}_{2} \mathrm{O}_{5}$ & $\mathrm{LOI}$ & Sum \\
\hline \multicolumn{13}{|c|}{ Gabbro } \\
\hline JS1411 & 49.90 & 10.20 & 22.80 & 2.33 & 2.95 & 4.50 & 5.73 & 0.28 & 0.10 & 0.18 & 0.08 & 99.00 \\
\hline JS1412 & 48.20 & 14.10 & 14.70 & 1.22 & 6.79 & 7.29 & 3.75 & 0.81 & 0.22 & 0.09 & 2.07 & 99.20 \\
\hline JS1413 & 47.60 & 13.70 & 13.30 & 1.30 & 6.41 & 7.64 & 4.35 & 0.94 & 0.22 & 0.09 & 3.44 & 99.00 \\
\hline JS1417 & 50.50 & 13.70 & 13.40 & 1.50 & 6.44 & 9.34 & 2.49 & 0.53 & 0.20 & 0.12 & 1.64 & 99.90 \\
\hline JS1419 & 48.70 & 13.40 & 12.40 & 0.65 & 8.22 & 9.41 & 3.22 & 0.20 & 0.32 & 0.04 & 2.41 & 99.00 \\
\hline BBF-031 & 49.00 & 11.80 & 18.00 & 2.00 & 4.12 & 6.23 & 5.54 & 0.61 & 0.15 & 0.15 & 1.31 & 98.90 \\
\hline \multicolumn{13}{|c|}{ Tholeiitic basalt and mafic tuff* } \\
\hline JS1415 & 47.10 & 14.00 & 15.10 & 1.25 & 6.46 & 8.80 & 3.13 & 0.23 & 0.25 & 0.09 & 2.11 & 98.50 \\
\hline JS1416 & 48.50 & 15.50 & 15.10 & 1.01 & 6.70 & 2.99 & 1.89 & 2.03 & 0.16 & 0.06 & 5.62 & 99.60 \\
\hline JS1418 & 49.30 & 13.30 & 13.60 & 1.56 & 6.37 & 11.30 & 1.68 & 0.32 & 0.19 & 0.11 & 1.85 & 99.60 \\
\hline JS1420 & 50.10 & 13.70 & 13.80 & 1.60 & 6.38 & 7.00 & 4.10 & 0.30 & 0.21 & 0.12 & 1.98 & 99.30 \\
\hline JS1430 & 48.60 & 13.00 & 14.00 & 1.60 & 6.01 & 10.80 & 2.17 & 0.26 & 0.20 & 0.12 & 1.96 & 98.70 \\
\hline JS1431 & 49.00 & 13.90 & 13.30 & 1.43 & 6.92 & 9.73 & 2.39 & 0.51 & 0.20 & 0.12 & 2.00 & 99.50 \\
\hline
\end{tabular}




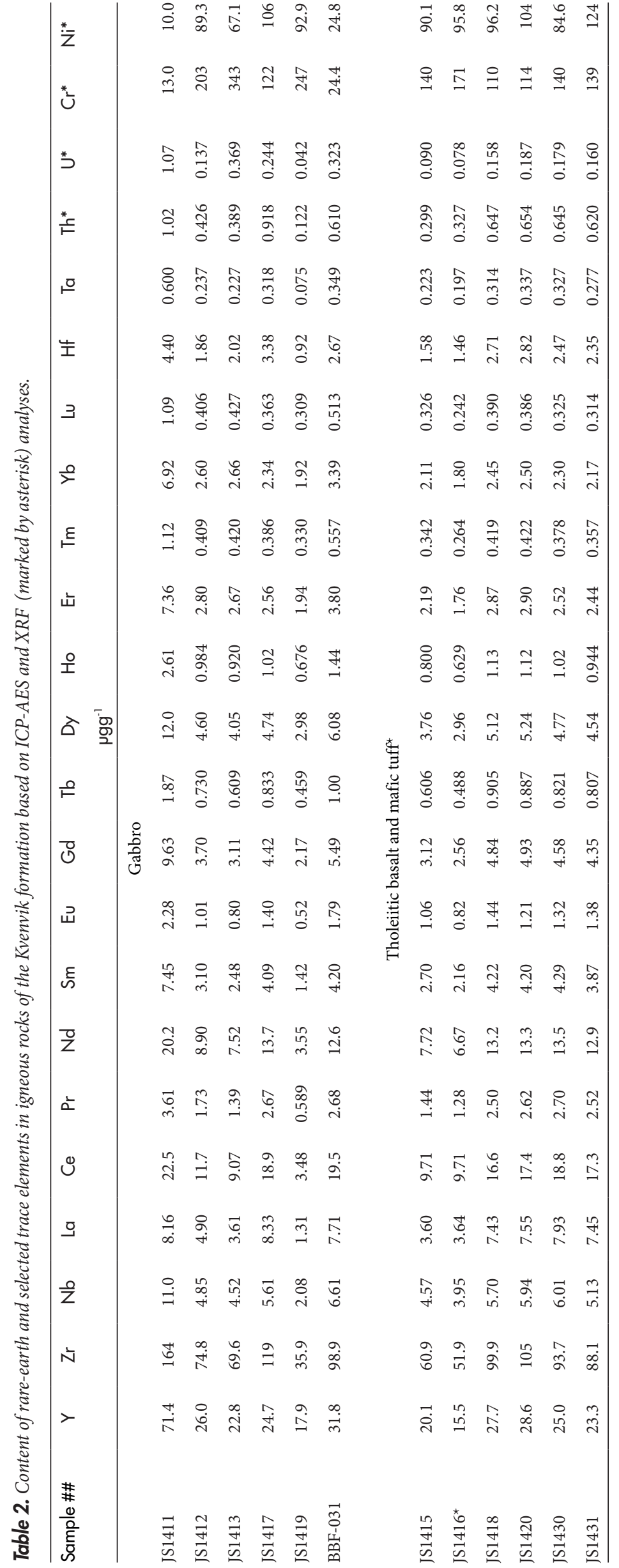

Major and trace element geochemistry, and $\mathrm{C}$ and $\mathrm{O}$ isotope ratios of the studied carbonate formations

\section{The Kvenvik formation}

Geochemical characteristics of the studied carbonate formations are based on 52 wholerock analyses (Table 4). Fifty out of the fifty-two analysed samples from all dolostone units in the Kvenvik formation contain a significant amount of silica $\left(\mathrm{SiO}_{2}=29 \pm 13\right.$ wt.\%; Fig. 15A). The albitised varieties in the Bergmark area show high $\mathrm{Na}_{2} \mathrm{O}$ contents (Fig. 15C, Table 4).

The Lower dolostone unit is composed of slightly calcitised dolostones $(\mathrm{Mg} / \mathrm{Ca}=0.55-0.58, \mathrm{n}=7)$ and minor limestones $(\mathrm{Mg} / \mathrm{Ca}=0.009-0.01, \mathrm{n}$ $=3) . \mathrm{Mn} / \mathrm{Sr}$ ratios are elevated in the dolostones $(15-41)$ and low in the limestones $(0.8-2.8)$. One of the limestone samples exhibits over $3 \mathrm{wt} . \% \mathrm{Ba}$ in the form of barite.

The Upper dolostone is composed mainly of calcitised dolostones $(\mathrm{Mg} / \mathrm{Ca}=0.34-0.68$, averaging at $0.48 \pm 0.08, \mathrm{n}=20)$ with elevated $\mathrm{Mn} / \mathrm{Sr}$ ratios (19-41). Two samples show a $\mathrm{Mg} /$ Ca ratio of 0.73 and 0.83 (Table 4, Fig. 15C), hence exceeding the 0.62 ratio of stoichiometric dolomite, and thus may contain a magnesite phase. These samples have high $\mathrm{Mn} / \mathrm{Sr}$ ratios (35-72).

The Uppermost dolostone unit consists of intensely calcitised dolostones $(\mathrm{Mg} / \mathrm{Ca}=0.03-$ $0.46, \mathrm{n}=10)$ having low $\mathrm{Mn} / \mathrm{Sr}$ ratios (4-13, Table 4). It remains unresolved whether or not two samples with $\mathrm{Mg} / \mathrm{Ca}$ ratios of 0.03 and 0.05 represent original limestones or intensely calcitised dolostones.

All carbonate rocks in the Lower, Upper and Uppermost dolostone units are rich in ${ }^{13} \mathrm{C}$. The $\delta^{13} \mathrm{C}$ values cluster tightly between +5.4 and $+8.5 \%$ o $(+7.4 \pm 0.7 \%$ o, $\mathrm{n}=51)$ with one outlier at $+1.7 \%$ o (Fig. $15 \mathrm{D}$, Table 4 ). In contrast, $\delta^{18} \mathrm{O}$ values are low $(15.9 \pm 2 \%, n=51)$ and show a significant fluctuation between 13 and 23.3\%. The lowest $\delta^{13} \mathrm{C}$ of $+1.7 \%$ is coupled with a low $\delta^{18} \mathrm{O}$ value of $14.1 \%$. If considered either all together or at the level of an individual formation/section, neither $\delta^{13} \mathrm{C}$ nor $\delta^{18} \mathrm{O}$ values show any significant correlation with $\mathrm{SiO}_{2}$ and $\mathrm{Na}_{2} \mathrm{O}$ abundances, nor with $\mathrm{Mg} / \mathrm{Ca}$ or $\mathrm{Mn} /$ $\mathrm{Sr}$ (Fig. 15). There is no significant correlation between $\delta^{13} \mathrm{C}$ and $\delta^{18} \mathrm{O}$. 


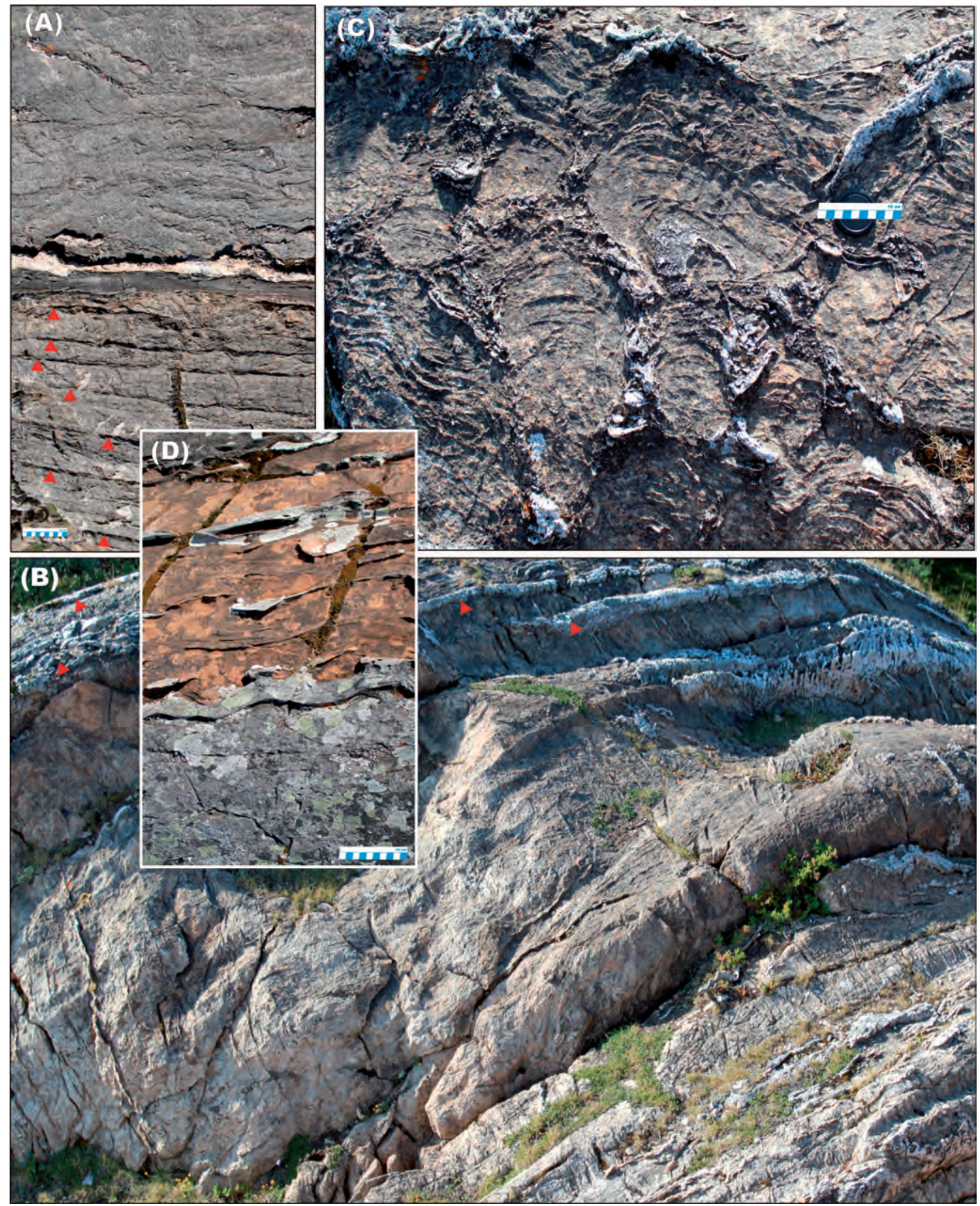

Figure 11. Images of natural outcrops illustrating the main sedimentological features of carbonate rocks of the Storviknes formation studied in Section 7 at Raipas. (A) Layered and structureless dolostones separated by dark-grey shale and calcitised interval (white). The layered dolostone consists of planar beds separated by thin layers of purple and grey shales (red arrowed). (B). A sharp-based, cupola-like body of structureless dolostone sandwiched between layered dolostones. The cupola-like body shows a massive appearance and resembles thrombolitic bioherms. The layered dolostone contains several interlayers of intensely silicified shale (red arrowed). (C) A biostrome composed of tightly packed, columnar and domal stromatolites with poorly preserved primary fabrics. Note that individual stromatolitic columns are separated from each other by intensely silicified shales (white). (D) Ripple-marked shale (overgrown with lichen) in sharp contact with a cross-bedded dolarenite containing shale layers with rippled surfaces. 


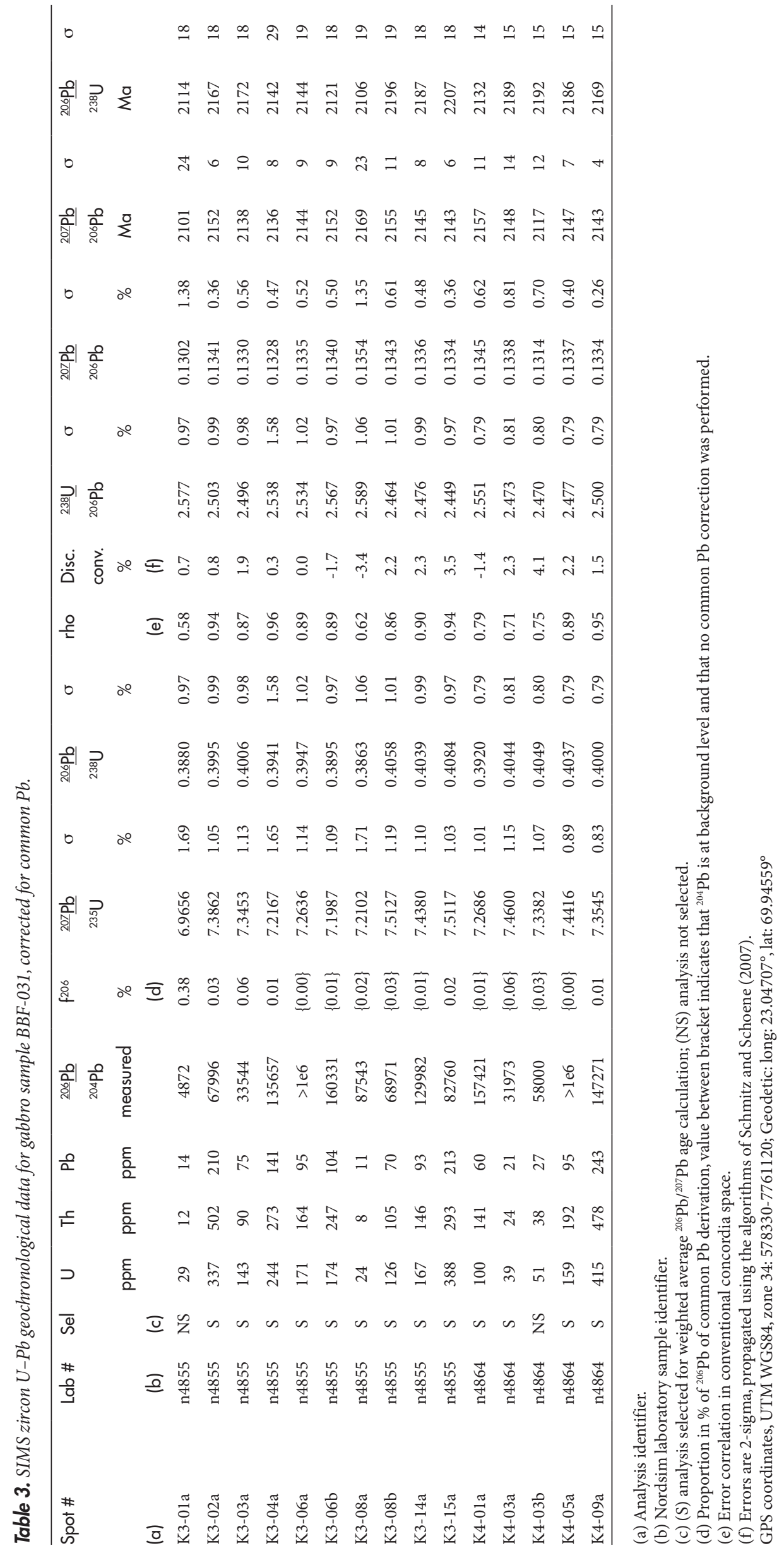




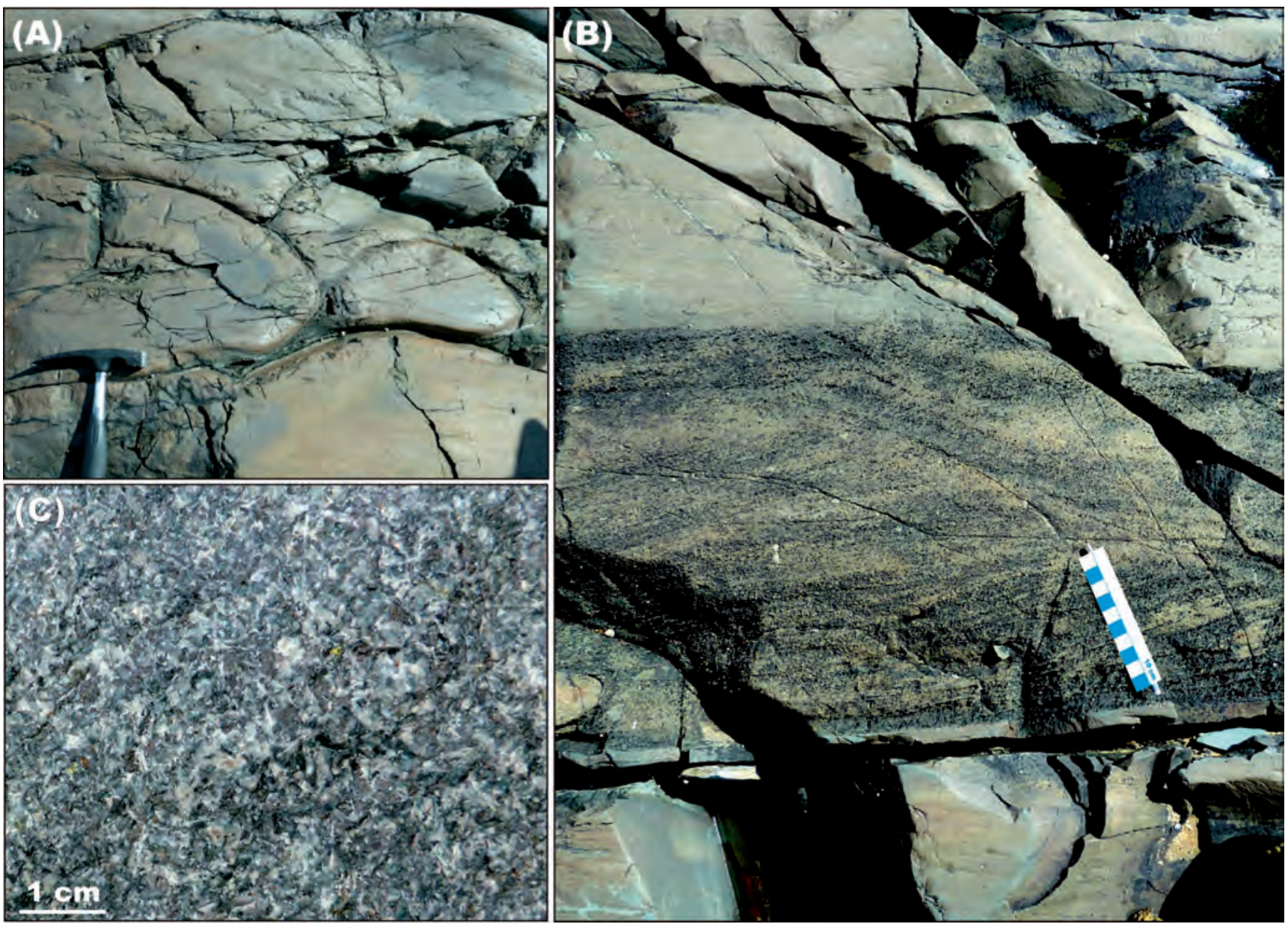

Figure 12. Selected images of igneous rocks comprising the Kvenvik formation in the Kåfjord area. (A) Tholeitic pillow lava. Hammer head for scale is $14 \mathrm{~cm}$. (B) Cross-bedded, volcaniclastic sandstone sandwiched between two lava flows. (C) A gabbro sill sampled for the radiometric age determination.

\section{The Storviknes formation}

Geochemical characteristics of the Storviknes formation carbonate rocks are based on 41 whole-rock analyses (Table 4). In contrast to the Kvenvik formation, all analysed samples contain much less silica $\left(\mathrm{SiO}_{2}=7.3\right.$ \pm 6.5 ; Fig. $15 \mathrm{~A}$ ) and are devoid of $\mathrm{Na}_{2} \mathrm{O}$, excluding two samples having 0.19 and 0.43 wt.\% $\mathrm{Na}_{2} \mathrm{O}$. In the Kåfjord and Raipas areas, all analysed samples are dolostones with an average $\mathrm{Mg} / \mathrm{Ca}$ ratio of $0.62 \pm 0.01(\mathrm{n}=36)$ which corresponds to that of stoichiometric dolomite. In contrast, all analysed samples from the Borras area are calcitic with $\mathrm{Mg} / \mathrm{Ca}$ ratios clustering tightly between 0.006 and $0.013(\mathrm{n}=5) . \mathrm{Mn} / \mathrm{Sr}$ ratios in all lithologies from all studied areas are low $(10.6 \pm 5.4, \mathrm{n}=40)$ with one dolostone outlier at 122 .

The carbonate rocks in the Storviknes formation are characterised by $\delta^{13} \mathrm{C}$ fluctuating around zero (-3.1 to $+2.8 \%$ ) with an average value of $+1.1 \pm 1.2 \%$ o ( $\mathrm{n}=$ 41, Table 4). Three out of four negative $\delta^{13} \mathrm{C}$ values are associated with the Borras limestones $(-3.1,-2.3$ and $-1.9 \% 0)$, and one with the Raipas dolostone $(-0.9 \% 0)$. The latter is marked by the highest $\mathrm{Mn} / \mathrm{Sr}$ ratio of 122
(Fig. 15E). The $\delta^{18} \mathrm{O}$ values in all dolostones are high $(22.3 \pm 1.1 \%$ o $\mathrm{n}=36)$ which also represents a significant difference from the dolostones of the Kvenvik formation which are generally ${ }^{18} \mathrm{O}$-depleted and ${ }^{13} \mathrm{C}$-rich (Fig. 15D). The Borras limestones are marked by low $\delta^{18} \mathrm{O}$ values ranging between 14.7 and $19.3 \%$ o $(16.5 \pm 2.3 \%, \mathrm{n}=5)$. The $\delta^{13} \mathrm{C}$ and $\delta^{18} \mathrm{O}$ values do not exhibit any significant correlation except for the Borras limestones. In all studied cases, neither of these isotopic compositions correlates significantly either with $\mathrm{SiO}_{2}$ abundances or with $\mathrm{Mg} / \mathrm{Ca}$ or $\mathrm{Mn} / \mathrm{Sr}$ ratios (Fig. 15).

\section{Geochemical screening of $C$ isotopes for post-depositional alteration}

Diagenetic, hydrothermal and metamorphic fluids have low water/rock ratios for carbon, but high water/rock ratios for oxygen (e.g., Hudson, 1977; Banner \& Hanson, 1990; Nabelek, 1991; Land, 1992; Jacobsen \& Kaufman, 1999). In rare cases, depletion in both oxygen and carbon isotope values has been reported from carbonate rocks that experienced a significant deformation (e.g., Guerrera 

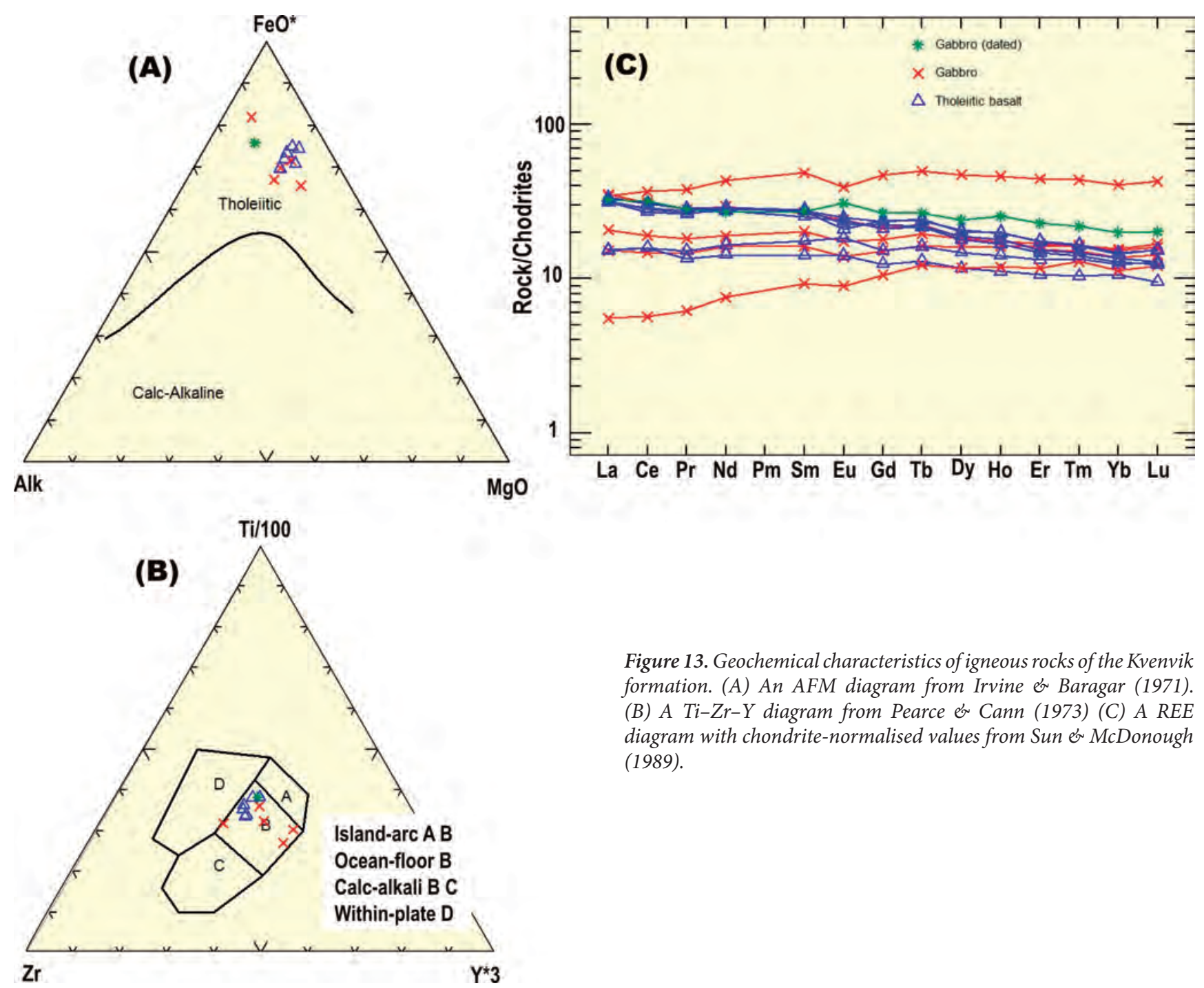

Figure 13. Geochemical characteristics of igneous rocks of the Kvenvik formation. (A) An AFM diagram from Irvine \& Baragar (1971). (B) A Ti-Zr-Y diagram from Pearce \& Cann (1973) (C) A REE diagram with chondrite-normalised values from Sun \& McDonough (1989).

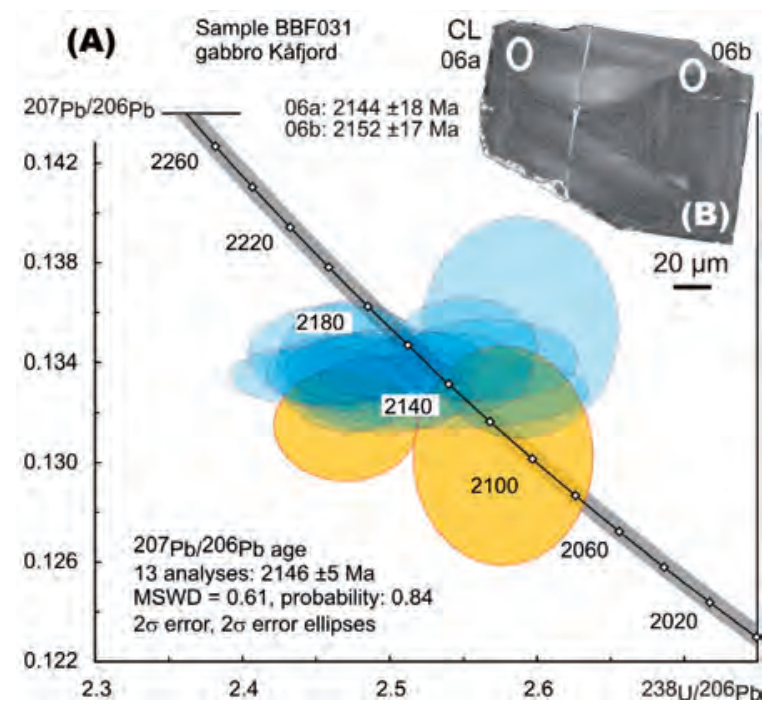

et al., 1997). Nevertheless, as a rule, oxygen isotopes are commonly much more easily affected by exchangeable oxygen derived from either meteoric water or interstitial fluids at elevated temperatures (e.g., Fairchild et al., 1990), whereas the carbon system is far more resilient during post-depositional, open-system recrystallisation (excluding organic diagenesis) because it is effectively buffered by the dissolving carbonate precursor. Consequently, in the following discussion, no attempt was made to reconstruct depositional $\delta^{18} \mathrm{O}$ values; rather, the oxygen isotope values and $\delta^{13} \mathrm{C}-\delta^{18} \mathrm{O}$ cross-plots have been utilised for tracking a degree of post-depositional recrystallisation.

For the studied carbonate rocks, the $\delta^{13} \mathrm{C}-\delta^{18} \mathrm{O}$ cross-plot shows significant positive correlation $(r=0.96,>99 \%, n=5)$ only for the Borras limestones (Fig. 15D), hence suggesting that only in this location could both isotope systems have been affected by alteration. Consequently, only the highest $\delta^{13} \mathrm{C}$ value at c. $1 \%$ is accepted as the least altered and as a proxy for the depositional C-isotope value. of Kåjord, intruded into the Kvenvik formation. The analyses in blue are selected for the average ${ }^{207} \mathrm{~Pb} /{ }^{206} \mathrm{~Pb}$ age calculation, while the analyses in yellow are probably affected by minor $\mathrm{Pb}$ loss. (B) Cathodoluminiscence (CL) image of a selected zircon crystal with the site of the $\mathrm{U}-\mathrm{Pb}$ analyses and corresponding ${ }^{207} \mathrm{~Pb} / 206 \mathrm{~Pb}$ age.

There is no significant correlation between $\delta^{13} \mathrm{C}$ and $\delta^{18} \mathrm{O}$ in all other studied carbonate rocks; however, the 

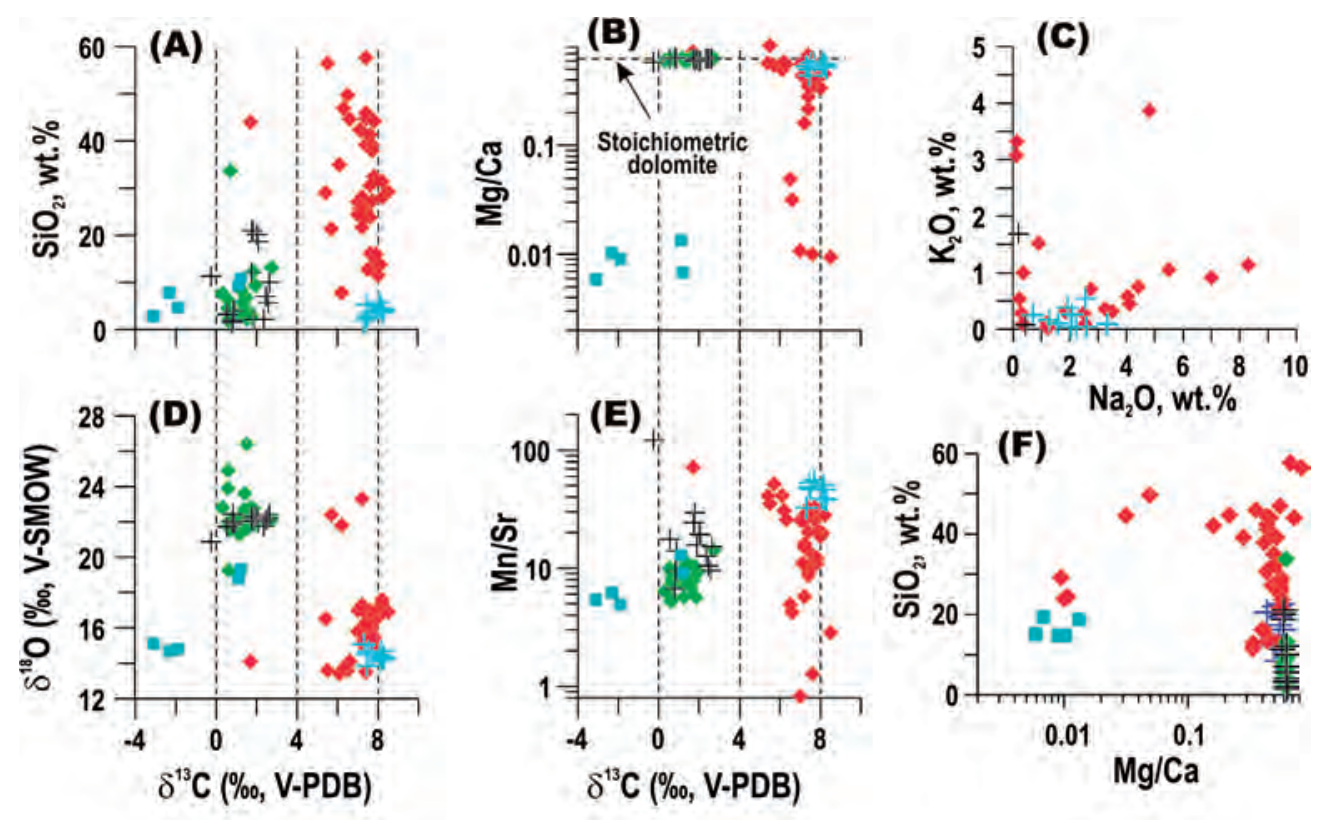

Figure 15. Various cross-plots demonstrating $C$-isotope and geochemical differences between carbonate rocks of the Kvenvik and Storviknes formations.

\begin{tabular}{|c|c|c|c|}
\hline \multicolumn{2}{|c|}{ Storviknes formation } & \multicolumn{2}{|c|}{ Kvenvik formation } \\
\hline † Kăfjord & + Raipas $=$ Borras & - Bergmark and Badderen & + Kăfjord \\
\hline
\end{tabular}
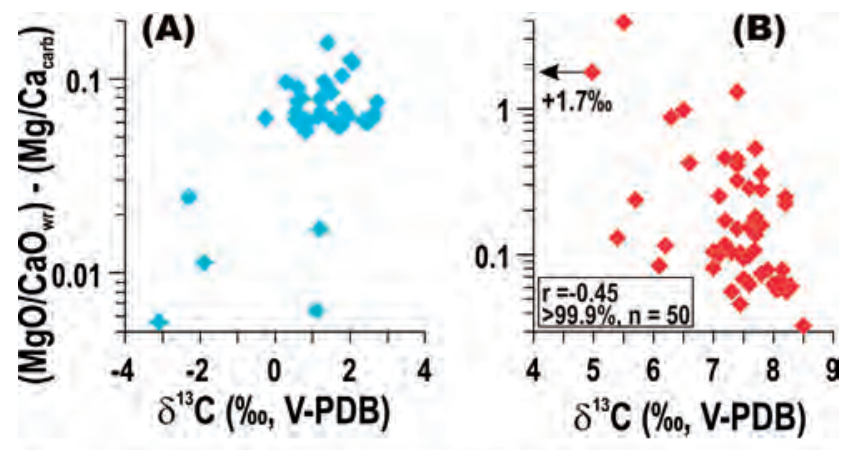

- Kvenvik formation + Storviknes formation

Figure 16. $\left(\mathrm{MgO} / \mathrm{CaO}{ }_{w r}\right)-\left(\mathrm{Mg} / \mathrm{Ca}_{\text {carb }}\right)$ versus $\delta^{13} \mathrm{C}$ cross-plots demonstrating a lack of correlation between the parameters for the Storviknes formation carbonates (A), and a strong negative correlation for the Kvenvik formation (B).

wide spread in oxygen isotope values recorded in each individual formation (Fig. 15D) reflects resetting of oxygen isotopes during post-depositional recrystallisation. This is particularly well pronounced in isotopically heavy carbonates from the Bergmark and Badderen areas. The observed limited spread in $\delta^{13} \mathrm{C}$ of $2-3 \%$ in each studied unit/section suggests that the alteration affect on the C-isotope system was rather limited.

In post-depositional processes, the $\mathrm{Mn}$ and $\mathrm{Sr}$ contents in carbonates would be partially shifted towards equilibrium with the ambient diagenetic/metamorphic fluids. Commonly, an increasing degree of postdepositional alteration by meteoric waters leads to $\mathrm{Sr}$ depletion and Mn enrichment (Veizer, 1983; Kaufman \& Knoll, 1995). Hence, Brand \& Veizer (1980) and Derry et al. (1992) reported that $\mathrm{Mn}$ and $\mathrm{Sr}$ abundances can serve as another tool for calibration of the relative diagenetic rank of lithostratigraphic successions. The common practice adopted in the exercise of extracting the leastaltered carbon isotope values is to selected samples with the lowest Mn/Sr ratios (e.g., Kaufman \& Knoll, 1995). However, in some cases precaution needs to be taken when assessing the effect of meteoric diagenesis in Palaeoproterozoic carbonates, which may have formed in an anoxic water enriched in $\mathrm{Fe}^{2+}$ and $\mathrm{Mn}^{2+}$ (e.g., Veizer et al., 1992; Bekker et al., 2001).

The absence of negative correlation between $\delta^{13} \mathrm{C}$ and $\mathrm{Mn} / \mathrm{Sr}$ ratios in the studied carbonates (Fig. 15E) does not indicate any apparent alteration, with just a few exceptions. The latter includes the two outlying samples from Bergmark and Raipas areas marked by high $\mathrm{Mn} / \mathrm{Sr}$ ratios (72 and 122, respectively; Fig. 15E) and showing a marked ${ }^{13} \mathrm{C}$ depletion $\left(\delta^{13} \mathrm{C}=+1.7 \%\right.$ and $-0.3 \%$, respectively). Thus, both samples are considered to be significantly altered.

In metamorphosed carbonate rocks another possible cause of alteration of C- and O-isotope systems can be associated with the greenschist-facies metamorphism, marked by the reaction:

$6\left[\mathrm{Ca}, \mathrm{Mg}\left(\mathrm{CO}_{3}\right)_{2}\right]+8 \mathrm{SiO}_{2}+2 \mathrm{H}_{2} \mathrm{O} \rightarrow$

$\mathrm{Mg}_{6}\left[\mathrm{Si}_{8} \mathrm{O}_{20}\right](\mathrm{OH})_{4}+6 \mathrm{CaCO}_{3}+6 \mathrm{CO}_{2}$

The dolomite + calcite \pm talc \pm actinolite paragenesis observed in some carbonate beds indicates that the aforementioned volatilisation reaction could have been 


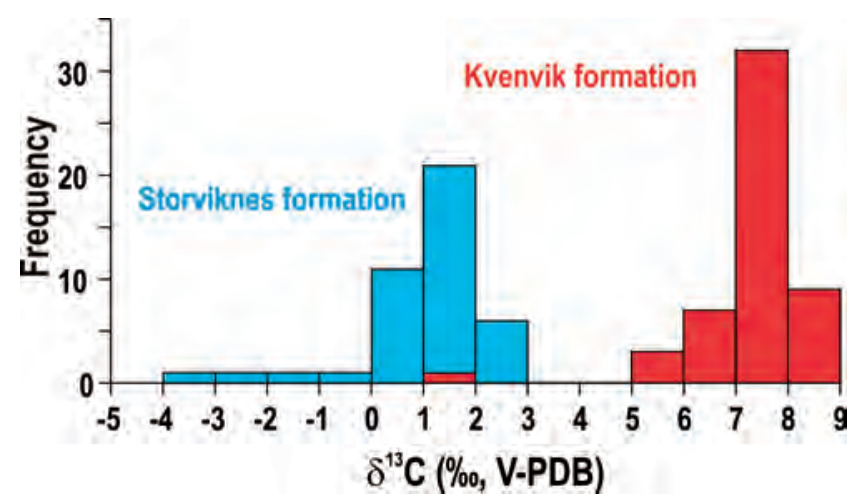

Figure 17. $\delta^{13} \mathrm{C}$ histogram showing distinctive differences in $\delta^{13} \mathrm{C}$ between carbonate rocks of the Kvenvik and Storviknes formations.

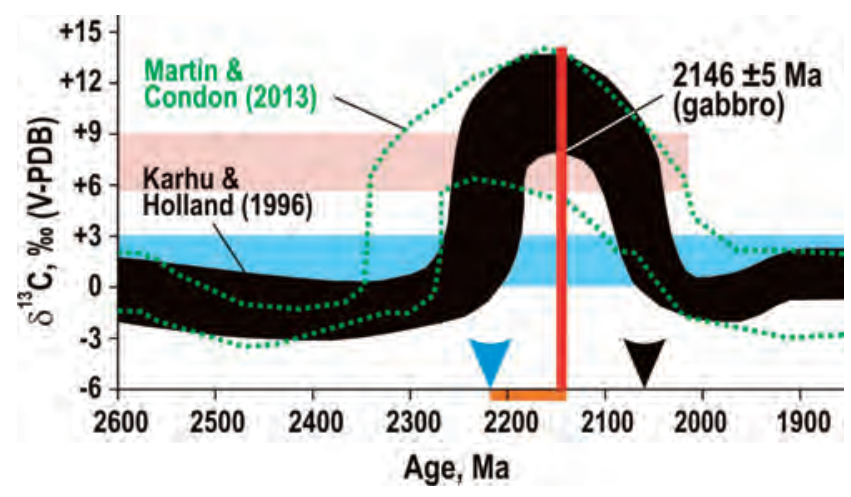

Figure 18. $\delta^{13} \mathrm{C}$ variability in Palaeoproterozoic carbonate formations based on $\mathrm{U}-\mathrm{Pb}$ and $\mathrm{Re}-\mathrm{Os}$ data. Modified after Karhu \& Holland (1996) and Martin \& Condon (2013). The horizontal pink and blue bars represent the range of $\delta^{13} \mathrm{C}$ for the Kvenvik and Storviknes carbonates, respectively. Red vertical line denotes the radiometric age for the gabbro emplacement, and consequently the upper age limit for the deposition of ${ }^{13} \mathrm{C}$-rich carbonates of the Kvenvik formation. The blue arrow indicates the start of deposition of ${ }^{13} \mathrm{C}$-rich carbonates constrained in the Fennoscandian Shield, hence setting the lower age limit for accumulation of the ${ }^{13} \mathrm{C}$-rich carbonates of the Kvenvik formation. The black arrow indicates the termination of deposition during the Lomagundi-Jatuli isotopic event in the Fennoscandian Shield and worldwide, thus providing the lower age limit for the deposition of the Storviknes formation carbonates. The horizontal orange bar projects the apparent depositional time-range of ${ }^{13} \mathrm{C}$-rich carbonate rocks of the Kvenvik formation.

the pathway influencing the $\delta^{13} \mathrm{C}$ and $\delta^{18} \mathrm{O}$ compositions of residual dolomite and newly formed calcite (Shieh \& Taylor, 1969; Bucher \& Frey, 2002). A case study research of carbonates metamorphosed under high-temperature greenschist-facies conditions demonstrated that $\delta^{13} \mathrm{C}$ may be reset in the order of $-1 \%$ in the precursor dolomite, up to $-3 \%$ in the metamorphic calcite, whereas $\delta^{18} \mathrm{O}$ can be depleted up to $6 \%$ in both newly formed carbonate components and their precursor (e.g., Melezhik et al., 2003). The significance of such a reaction and consequently its effect on the $\mathrm{C}$-isotope system is commonly identified by the presence of: (i) talc or tremolite; (ii) discrepancy between whole-rock $\mathrm{MgO} / \mathrm{CaO}_{\text {wr }}$ and $\mathrm{Mg} / \mathrm{Ca}_{\text {carb }}$ bound to carbonate phases; (iii) a negative correlation between $\delta^{13} \mathrm{C}$ and $\mathrm{SiO}_{2}$; and (iv) a positive correlation between $\delta^{13} \mathrm{C}$ and $\mathrm{Mg} / \mathrm{Ca}$ ratio.
The amount of tremolite or talc is insignificant in the dolostones of the Storviknes formation. The correlations stated in (iii) and (iv) are not seen in Fig. 15A, B, and the discrepancy described in (ii) is insignificant (Fig. 16A); hence, all collectively suggest that the effect of alteration specified in (1) is also insignificant.

A moderate amount of tremolite is a characteristic feature of the dolostones from the Kvenvik formation occurring in the Badderen area. A strong negative correlation between $\delta^{13} \mathrm{C}$ and $\left(\mathrm{MgO} / \mathrm{CaO}_{\text {wr }}\right)-\left(\mathrm{Mg} / \mathrm{Ca}_{\text {carb }}\right)$ observed in the dolostones of the Kvenvik formation (Fig. $16 \mathrm{~B} ; \mathrm{r}=-0.45,>99.9 \%, \mathrm{n}=51$ but one extreme value of $+1.7 \%$ is excluded) is in accord with the petrographic observations. Consequently, depositional $\delta^{13} \mathrm{C}$ values of some dolostones with elevated differences in $(\mathrm{MgO} /$ $\left.\mathrm{CaO}_{\text {wr }}\right)-\left(\mathrm{Mg} / \mathrm{Ca}_{\text {carb }}\right)$ might have been slightly lowered (by $\leq 1 \%$; e.g., Melezhik et al., 2003).

In a $\delta^{13} \mathrm{C}$ histogram, the isotopically normal and heavy values exhibit two distinct, separate, unimodal distributions (Fig. 17). The former is skewed with a thin negative tail suggesting that all samples with $\delta^{13} \mathrm{C}<0 \%$ are very likely altered. The distribution of the isotopically heavy values shows only an insignificant skew; hence, the depositional isotopic ratios show an overall better preservation.

\section{Discussion}

\section{Depositional age constraint of the studied} carbonate formations

The radiometric date of $2146 \pm 5 \mathrm{Ma}$ obtained from the gabbro intruding dolostones of the Kvenvik formation provides a minimum age limit for the deposition of the ${ }^{13} \mathrm{C}$-rich carbonates of the Lower and Upper dolostone units in Member A. Moreover, being co-magmatic with tholeiitic basalts of Member B of the same formation, this date also constrains the deposition of the ${ }^{13} \mathrm{C}$-rich carbonates in the Uppermost dolostone unit which is sandwiched between such lavas (Fig. 3). In addition, being co-magmatic with tholeiitic basalts of Member B of the Kvenvik formation, the date of $2146 \pm 5 \mathrm{Ma}$ constrains a maximum age limit for the deposition of the isotopically normal carbonates of the Storviknes formation (Fig. 3).

A further constraint on the deposition of both groups of carbonate rocks can be provided by means of the carbon isotope chemostratigraphy. The Early Palaeoproterozoic is known for a well-documented global positive excursion of carbonate carbon isotopes in sedimentary carbonates, namely the Lomagundi-Jatuli isotopic event (reviewed in Melezhik et al., 2013a; Fig. 18).

Worldwide compilations of available radiometric dates allow us to constrain the isotopic event between 2300- 
2220 and $2060 \mathrm{Ma}$ (Martin \& Condon, 2013; Martin et al., 2013). Recently, Martin et al. (2014) have suggested that a maximum permitted range could be placed between 2306 \pm 9 and $2057 \pm 1 \mathrm{Ma}$, and a minimum permitted range between $2221 \pm 5$ and $2106 \pm 8 \mathrm{Ma}$. On the Fennoscandian Shield alone, the Lomagundi-Jatuli isotopic event has been confidently constrained in several places between $c$. 2220 and $2060 \mathrm{Ma}$ (Karhu, 2005; Melezhik et al., 2007; Fig. 18). Consequently, the latter constraint combined with the obtained isotopic composition of carbonate rocks and available radiometric date of $2146 \pm 5 \mathrm{Ma}$ permit us to place the depositional age of the ${ }^{13} \mathrm{C}$-rich carbonates of the Kvenvik formation between $c .2220$ and $2146 \pm 5 \mathrm{Ma}$ (Fig. 18).

Based on similar reasoning, the deposition of isotopically normal carbonate rocks of the Storviknes formation should either pre-date or post-date the LomagundiJatulu isotopic event (Fig. 18). However, red beds (Fig. 9) and stromatolitic carbonate rocks (Fig. 11) have not been documented in the Fennoscandian Shield prior to 2220 Ma.In contrast, these lithologies are known in sedimentary successions younger than $2060 \mathrm{Ma}$ (Melezhik \& Hanski, 2012a; McLoughlin et al., 2013), and the $2146 \pm 5 \mathrm{Ma}$ age on the underlying Kvenvik formation gabbro and co-magmatic lava flows also suggests that the Storviknes carbonates should post-date the LJE. Consequently, the deposition of the Storviknes carbonate formations is very likely younger than $2060 \mathrm{Ma}$, and currently cannot be constrained more precisely.

Litho- and chronostratigraphic correlation with the Palaeoproterozoic sedimentary and volcanic successions of the main part of the Fennoscandian Shield

Several attempts have been made to provide detailed correlations between the sedimentary-volcanic successions of the AKTW and those occurring in the main part of the Fennoscandian Shield in northern Norway (e.g., Pharaoh et al., 1983; Bergh \& Torske, 1986, 1988). Due to the frequent lithofacies variations and the lack of reliable age determinations, all correlation schemes have remained only provisional (e.g., Bergh \& Torske, 1988). However, aeromagnetic maps revealed that the supracrustal sequences of the AKTW are connected underneath the Caledonian nappes with those in the Kautokeino Greenstone Belt occurring to the south ( $\AA \mathrm{m}$, 1975, Olesen \& Solli, 1985, Olesen et al. 1990; Fig. 19).

A recent project (ICDP Fennoscandian Arctic Russia - Drilling Early Earth Project, Melezhik (2012a)) provided comprehensive information on litho- and chronostratigraphy, depositional ages and palaeotectonic evolution of the Fennoscandian Shield in the Early Palaeoproterozoic (Hanski \& Melezhik, 2012; Melezhik \& Hanski, 2012a). This represents a valuable database which

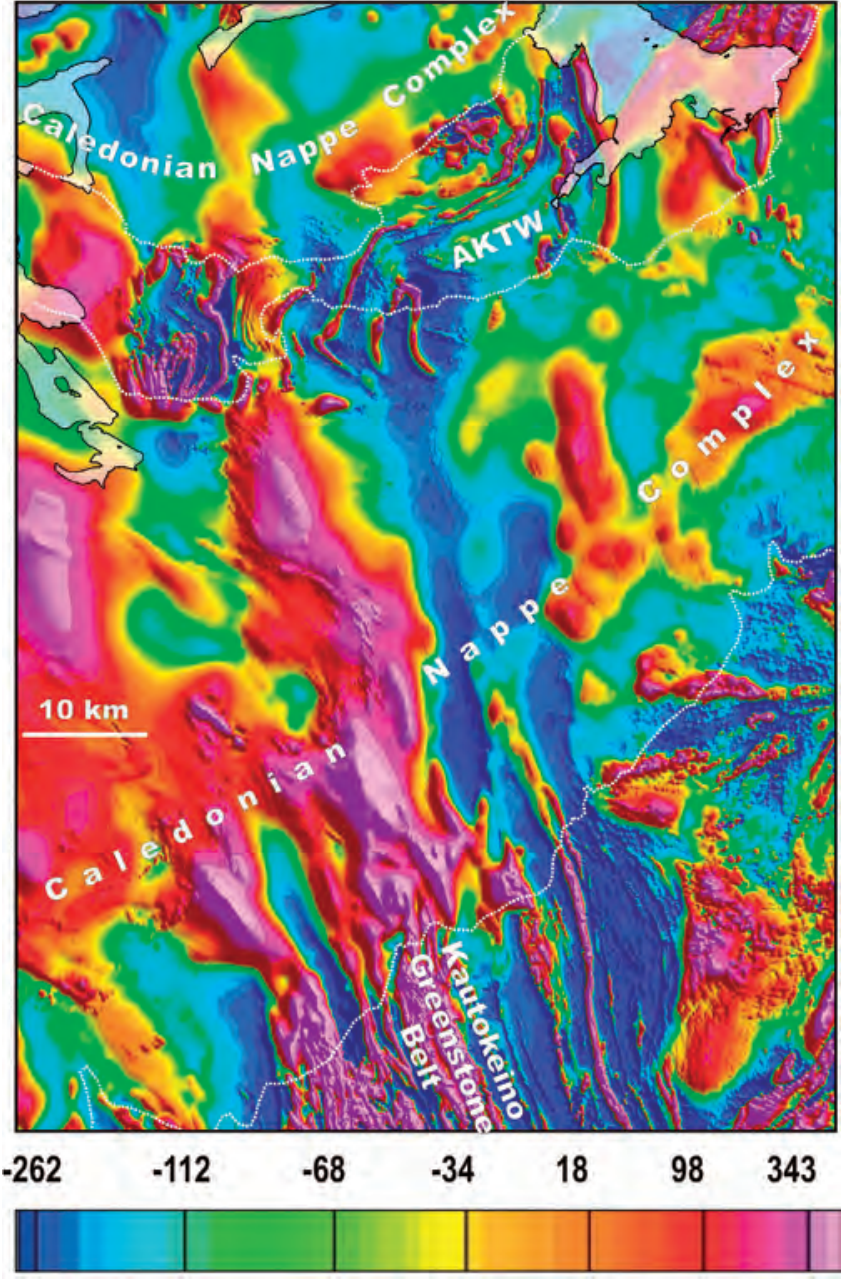

\section{Magnetic anomaly (nT)}

Figure 19. Aeromagnetic anomaly map over the AKTW and the northern part of the Kautokeino Greenstone Belt (Nasuti et al., 2015). Note that the sedimentary-volcanic formations occurring in the western and central parts of the AKTW are traceable beneath the Caledonian Kalak Nappe Complex into the Kautokeino Greenstone Belt.

allows the correlation of Palaeoproterozoic sedimentaryvolcanic successions across the Fennoscandian Shield.

First of all, sedimentary successions bearing ${ }^{13} \mathrm{C}$-rich carbonate formations whose depositional ages have been constrained in northern Fennoscandian to 2220$2060 \mathrm{Ma}$ provide an invaluable tool for chemo- and chronostratigraphic correlation. Such correlation suggests that the ${ }^{13} \mathrm{C}$-rich carbonate units of the Kvenvik formation have chemo- and chronostratigraphic correlatives in all major greenstone belts and depositional sites across the Finnish, Swedish and Russian parts of the Fennonscandian Shield. Fig. 20 exemplifies such a correlation.

The ${ }^{13} \mathrm{C}$-rich carbonate units of the Fennoscandian Shield show diverse lithofacies including lacustrine red-coloured dolarenites, shallow-marine stromatolitic dolostones, beds of dissolution breccias, and deep-water dolarenites, many of which have been documented in the 


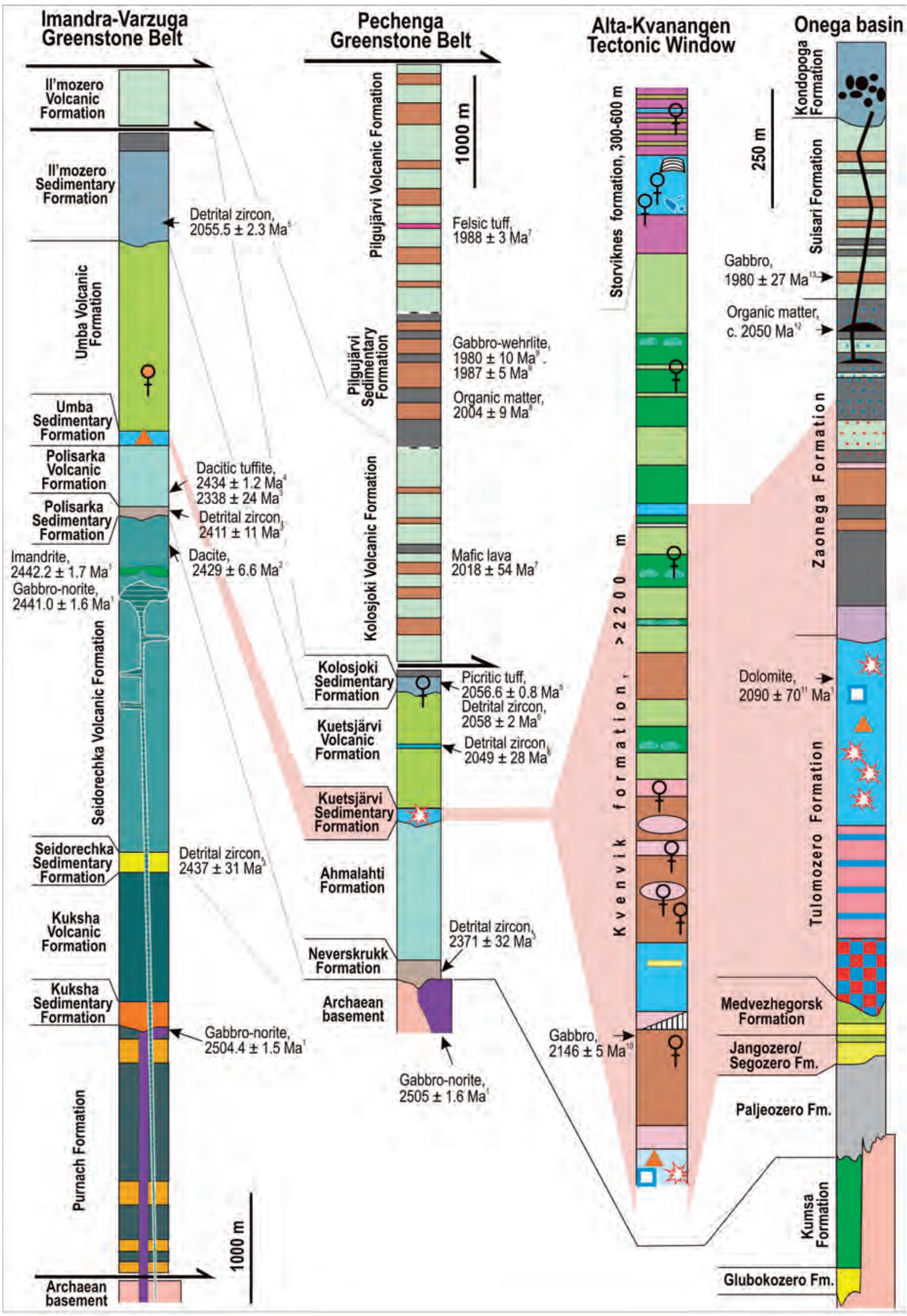

Figure 20. Correlation of the AKTW sedimentary-volcanic succession with those occurring in other belts and palaeobasins in the main part of the Fennoscandian Shield. The correlation is based on chemostratigraphic data $\left({ }^{13} \mathrm{C}\right.$-rich sedimentary carbonates denoted by pale-pink field) and published radiometric dates. The radiometric dates are from: 1 - Amelin et al. (1995), 2 - Vrevsky et al. (2010), 3 - Gärtner et al. (2014), 4 - Brasier et al. (2013), 5 - Martin et al. (2013), 6 - Melezhik et al. (2007), 7 - Hanski et al. (2014), 8 - Hannah et al. (2006), 9 - Skuf'in \& Bayanova (2006), 10 - this study, 11 - Ovchinnikova et al. (2007), 12 - Hannah et al. (2008), 13 - Puchtel et al. (1992, 1998). 
Kvenvik formation (Figs. 4-8). Importantly, the ${ }^{13} \mathrm{C}$-rich carbonate units in many studied sites in Fennoscandia and worldwide share one common feature: they contain barite, pseudomorphed calcium sulphates and, in places, halite casts (Fig. 21A-F; Melezhik et al., 2013a; Strauss et al., 2013). Such features are also documented in the Bergmark area (Fig. 4D, E). All collectively allow a strong assumption of widespread former sulphates and halite coeval with the Lomagundi-Jatuli isotopic event. Recently, this assumption has been justified by the discovery of an over $190 \mathrm{~m}$-thick bed of halite and an over $200 \mathrm{~m}$-thick formation of massive anhydrite preserved at a depth of $3000 \mathrm{~m}$ below the surface and recovered in cores of a parametric well drilled in the Onega basin (Fig. 1; Morozov et al., 2010; Krupenik et al., 2011a). These beds of halite and $\mathrm{Ca}$-sulphates, preserved at the base of ${ }^{a}{ }^{13} \mathrm{C}$-rich dolostone formation (Figs. $20 \& 21 \mathrm{G}, \mathrm{H}$ ), have been taken as robust evidence for the establishment of a sizeable seawater sulphate reservoir formed in response to a significant oxidation of terrestrial atmosphere and hydrosphere (e.g., Melezhik et al., 2005; Reuschel et al., 2012; Kump et al., 2013). For the first time in Earth's history, Ca-sulphates were widespread and forming in sedimentary basins worldwide (e.g., Strauss et al., 2013).

\section{Apparent nature and fluid source for albitisation and scapolitisation}

The bulk of the sedimentary and volcanic rocks spatially associated with $\mathrm{Cu}$-sulphide occurrences and deposits in the Bergmark area (Sections 1 and 3) show a significant degree of albitisation (Table 4, Fig. 3). In places, the albitisation resulted in the formation of $\mathrm{Na}_{2} \mathrm{O}$-rich rocks, locally termed 'albite felsites'. Some intervals have been intensively scapolitised (e.g., Vik, 1985). This alteration phenomenon, however, does not represent a small-scale regional exception. Widespread chlorine and sodium metasomatism in Palaeoproterozoic volcanosedimentary and igneous rocks has been documented throughout northern Fennoscandia (Fig. 1). In northern Sweden and Finland and adjacent parts of Norway and Russia, the areal extent of scapolitised and albitised Palaeoproterozoic rocks covers over several hundred square kilometres, and represents the largest known scapolite-bearing Precambrian terrane in the world (e.g., Frietsch et al., 1997). In places, the formation of scapolite and albite is accompanied by calcitisation and tourmalinisation. Interestingly, a number of epigenetic $\mathrm{Cu}-\mathrm{Au})$ sulphide and $\mathrm{Fe}$ oxide deposits in northern Fennoscandia show a spatial and genetic relationship to Cl-Na metasomatism (e.g., Frietsch et al., 1997; Eilu et al., 2007).

Frietsch et al. (1997) reported that scapolite is mainly represented by a $\mathrm{Cl}$ and $\mathrm{CO}_{3}$ species with small amounts of $\mathrm{SO}_{4}$ and $\mathrm{F}$, thus indicating high $\mathrm{Na}$ and $\mathrm{Cl}$ activity at the time of crystallisation. Fluid inclusion data obtained from several $\mathrm{Cu}-\mathrm{Au}$ deposits indicate ore deposition from highly saline aqueous solutions under temperatures of $\approx 300^{\circ} \mathrm{C}$ (e.g., Ettner et al., 1994). Frietsch et al. (1997) speculated that the source of $\mathrm{Cl}, \mathrm{Na}, \mathrm{SO}_{4}$ and $\mathrm{F}$ might derive from 2500-2000 Ma hypothetical evaporitic sequences or high-salinity brines formed in rift basins with active mafic volcanism. However, they acknowledged that the ultimate source of saline fluids remains enigmatic. They also admitted that evaporites and brines might have been mobilised through multiphase igneous activities and regional metamorphism and transported to their present positions during multiple metasomatic phases.

The recent discovery of over 200 m-thick beds of Palaeoproterozoic halite and massive anhydrite in the Onega basin (Figs. 20 \& 21G, H) may shed light upon the most probable source of $\mathrm{Cl}, \mathrm{Na}$ and $\mathrm{SO}_{4}$ in metasomatically altered rocks in northern Fennoscandia. These thick deposits of halite and anhydrite in the Onega basin represent a uniquely preserved salt accumulation which apparently expresses only a small fraction of what had originally been accumulated on a large scale. Northern Fennoscandia holds the best preserved rock record characterising this period (e.g., Melezhik, 2012a)

It appears that these Early Palaeoproterozoic salts, having once been accumulated in great abundance, had been largely dissolved and remobilised during orogenic, magmatic and metamorphic alteration processes throughout a $2100 \mathrm{Myr}$ post-depositional history, and as a rule largely lost from the rock record. However, they left behind abundant pseudomorphs, casts and dissolutioncollapse breccias as well as diagenetic, metasomatic and hydrothermal albitisation, calcitisation and scapolitisation. All such features have been abundantly recorded across northern Fennoscandia in the Bergmark (Vik, 1985; this study), Kautokeino (Olerud, 1988; Ettner et al., 1994), Kiruna (Frietsch, et al., 1997), Central Lapland (Tuisku, 1985; Eilu, 1994; Mänttäri, 1995), Kuusamo (Vanhanen, 2001), Peräpohja (Kyläkoski et al., 2012) and Onega (Melezhik et al., 2012, 2013b) areas. The isotopic compositions of the components, e.g., ${ }^{34} \mathrm{~S} /{ }^{32} \mathrm{~S}$ known from the Onega Parametric Hole $\left(\delta^{34} \mathrm{~S}=+4\right.$ to $+8 \%$, e.g., Krupenik et al., 2011b; Strauss et al., 2013), could provide a test of this hypothesis.

\section{Depositional history of the Alta-Kvænangen succession in the Fennoscandian palaeogeo- graphic framework}

Based on the carbon isotope stratigraphy and reported radiometric date, the depositional history of the AltaKvænangen succession can be placed somewhere between 2220-2146 and <2060 Ma (Fig. 18). This succession, however, does not represent a continuous rock record. The date of $2146 \pm 5 \mathrm{Ma}$ constrains the emplacement of the gabbro. Importantly, this date also constrains the timing of coeval extrusive volcanism terminating the deposition of the Kvenvik formation. The deposition of the 


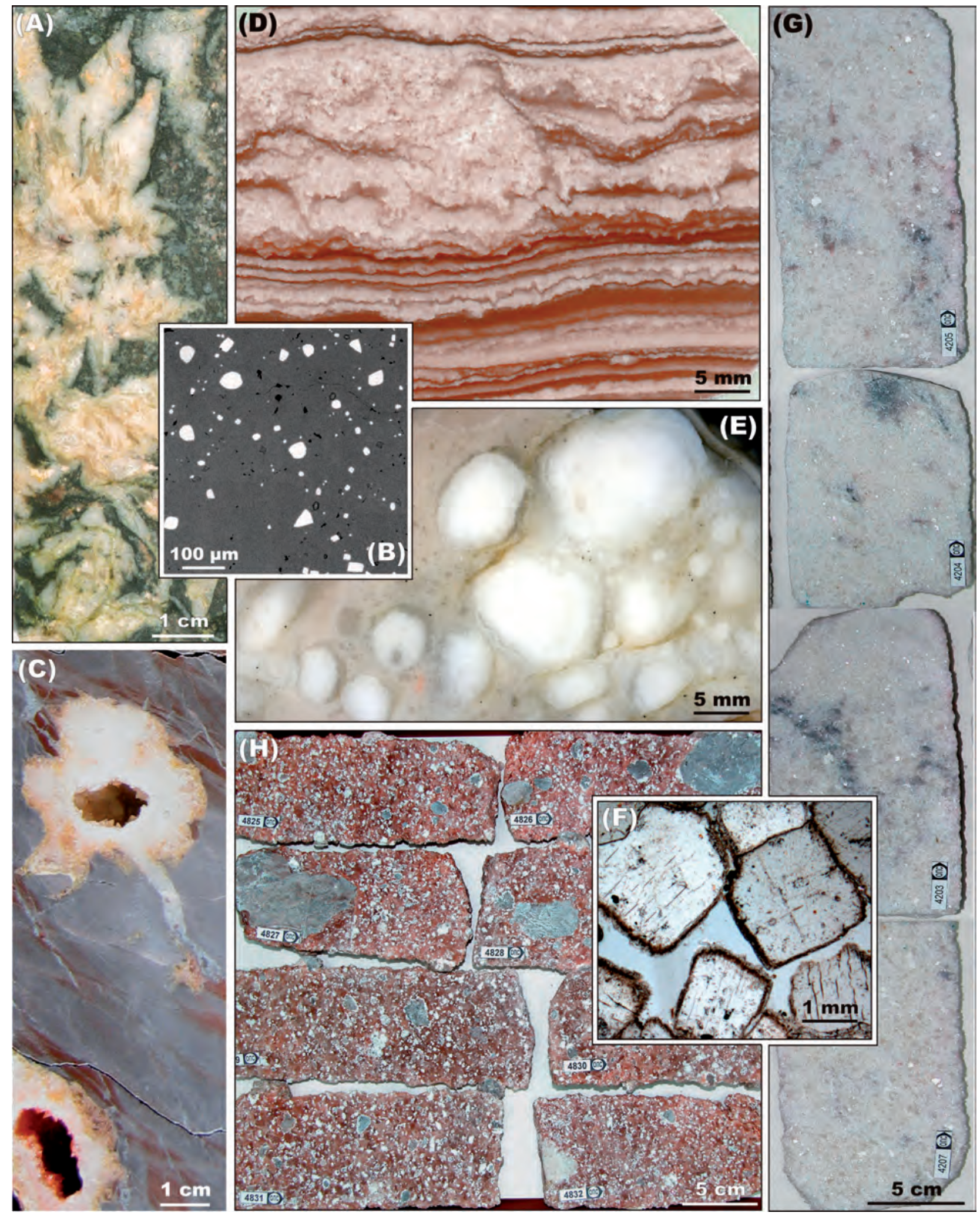

Figure 21. Selected images of massive anhydrite and halite, and pseudomorphed sulphates documented in Early Palaeoproterozoic sedimentary rocks of the Fennoscandian Shield. (A) Dolomarl-hosted, quartz-pseudomorphed gypsum rosettes. (B) Back-scattered electron image of anhydrite relics preserved in quartz-pseudomorphed sulphate nodule. (C) Mudstone-hosted, quartz-pseudomorphed sulphate nodules with hollow core. (D) Former sulphate nodule (white) hosted by interlaminated red mudstone and white sulphates exhibiting enterolithic folds. (E) Sandstone-hosted former sulphate nodules replaced by quartz. (F) Former halite crystals replaced by dolomite. (G) Sawn core of massive anhydrite bed from the Onega parametric hole in the Onega palaeobasin (for the hole location, see Fig. 1). (H) Sawn core of massive halite with numerous inclusions of anhydrite and magnesite (white) and shale (grey) from the Onega parametric hole in the Onega palaeobasin. (A-D, F-H) Tulomozero Formation in the Onega palaeobasin; (E) Kuetsjärvi Sedimentary Formation in the Pechenga Greenstone Belt. (A, D) modified from Melezhik et al. (2005), (C) modified from Melezhik et al. (2013c), (E) modified from Melezhik \& Hanski (2012b), (F) modified from Melezhik et al. (2013d), (G, H) courtesy of D. Rychanchik. 


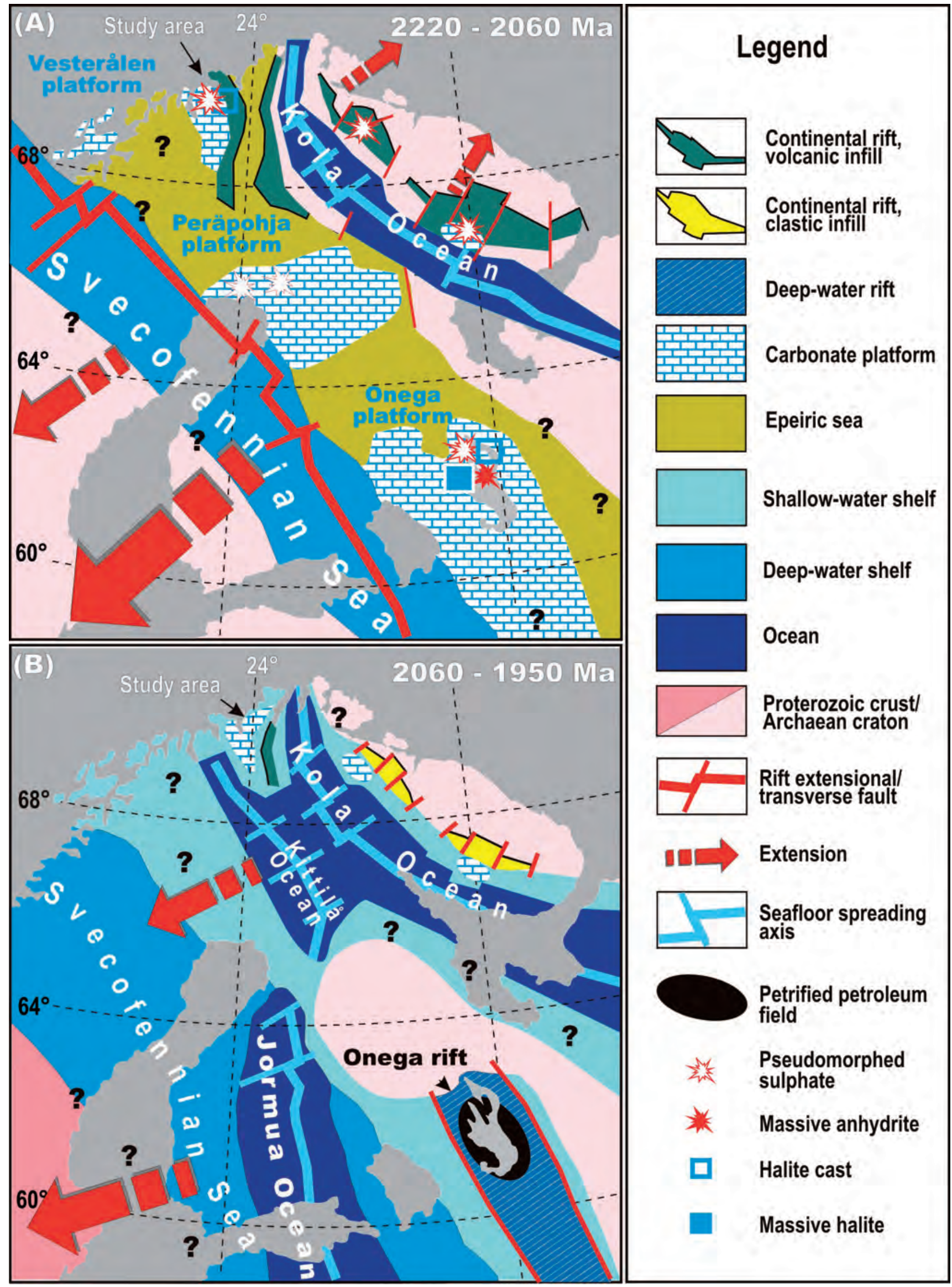

Figure 22. Major stages of palaeotectonic and palaeogeographic evolution of the Fennoscandian Shield in the Mid Palaeoproterozoic (2220-1950 Ma). Due to the lack of robust palaeomagnetic data, the time-slice reconstructions were made based on the present-day locations. Modified after Melezhik \& Hanski (2012a). 
structurally overlying carbonate units of the Storviknes formation is younger than $2146 \pm 5 \mathrm{Ma}$ and most likely post-dated $2060 \mathrm{Ma}$ (Fig. 18). Consequently, a hiatus of over $80 \mathrm{Myr}$ or more separates the depositional history of the two adjacent formations (Fig. 3).

The ${ }^{13} \mathrm{C}$-rich dolostones forming the base of the Kvenvik formation (Lower and Upper dolostone in Member A; Fig. 3 ), and whose deposition is older than $2140 \pm 5 \mathrm{Ma}$, occur in a large array of lithofacies representing depositional environments including an oxic coastal sabkha, a carbonate shelf, and the slope of a carbonate platform. The lithology, the depositional settings, and the ${ }^{13} \mathrm{C}$-rich nature of the carbonate rocks fit well with the major environmental components of c. 2220-2060 Ma period inferred for the Fennoscandian Shield (Fig. 22A). This period was marked by (i) the development of an epeiric sea with several carbonate platforms; (ii) deposition of diverse carbonate lithologies and accumulation of abundant $\mathrm{Ca}$-sulphates (oxic seawater); (iii) widespread 'red beds" $\left(\mathrm{O}_{2}\right.$-rich atmosphere); and (iv) formation of ${ }^{13} \mathrm{C}$-rich sedimentary carbonates representing the Lomagundi-Jatuli perturbation of the global carbon cycle (Melezhik \& Hanski, 2012a). In the Fennoscandian palaeogeographic context, the ${ }^{13} \mathrm{C}$-rich carbonates of the Kvenvik formation may represent a part of the Vesterålen carbonate platform (Fig. 22A).

The ${ }^{13} \mathrm{C}$-rich dolostones, forming the middle part of the Kvenvik formation (the Uppermost dolostone in Member B; Fig. 3), whose deposition was coeval with the $2140 \pm 5$ $\mathrm{Ma}$ intensive mafic volcanism, accumulated in a deepwater shelf setting. This is again consistent with the general palaeotectonic evolution of the Fennoscandian Shield whose geotectonic regime was marked by the break-up of the continental crust at c. $2100 \mathrm{Ma}$. This resulted in the opening of the Kola Ocean between the Kola and Karelian cratons (Fig. 22A).

The 2140-2060 Ma period is missing in the AltaKvænangen succession. Sedimentological features of the Storviknes sedimentary rocks suggest that the shale accumulated in an oxic environment, whereas the carbonate deposition was in an intertidal setting within a channellised carbonate platform and its slope. Such an environment closely resembles the depositional setting reconstructed for time-equivalent successions documented elsewhere in the Fennoscandian Shield. The Il'mozero Sedimentary Formation from the Imandra/ Varzuga Greenstone Belt represents such an example (Melezhik, 2012b; Fig. 22B).

\section{Conclusions}

The aeromagnetic map demonstrates that the sedimentary-volcanic succession exposed in the AltaKvænangen Tectonic Window (AKTW) in the northern Norwegian Caledonides is connected beneath the Kalak Nappe Complex with the main part of the Fennoscandian Shield, forming a northern extension of the Kautokeino Greenstone Belt.

Carbon isotope chemostratigraphy combined with the zircon $\mathrm{U}-\mathrm{Pb}$ date for a gabbro constrains the deposition of the Kvenvik formation containing ${ }^{13} \mathrm{C}$-rich carbonates to between $<2220$ and $2146 \pm 5 \mathrm{Ma}$, whereas the accumulation of the Storviknes formation sedimentary succession with isotopically 'normal' carbonates is younger than $2146 \pm 5 \mathrm{Ma}$ and most likely occurred after $2060 \mathrm{Ma}$. The deposition of these two formations is separated by an over $80 \mathrm{Myr}$ non-depositional break/ hiatus.

The deposition of the Kvenvik formation, which contains ${ }^{13} \mathrm{C}$-rich carbonates, records a global positive excursion of carbonate carbon isotopes in sedimentary carbonates known as the Lomagundi-Jatuli isotopic event.

The deposition of ${ }^{13} \mathrm{C}$-rich carbonates in the AKTW is marked by accumulation of $\mathrm{Ca}$-sulphates and halite which accords with an abundant formation of $\mathrm{CaSO}_{4}$ and $\mathrm{NaCl}$ in time-equivalent successions across the Fennoscandian Shield. These sedimentary sulphates and halite are inferred to represent the most plausible source for the $\mathrm{Na}$ and $\mathrm{Cl}$ metasomatism that affected Palaeoproterozoic sedimentary and volcanic rocks in the AKTW and across northern Fennoscandia.

Geochemical and petrological characteristics of volcanic rocks of the older part of the AKTW succession suggest an intraplate rift environment. Sedimentological features of carbonate rocks in all formations are consistent with deposition within a carbonate platform/shelf, whereas siliciclastic sedimentary rocks were apparently accumulated in a shallow-water epeiric sea.

Acknowledgements. SIMS data were collected at the NORDSIM laboratory, hosted at the Swedish Museum of Natural History. M. Whitehouse, L. Ilyinsky and K. Lindén guided collection of SIMS data. Carbon and oxygen isotope analyses were supported by the Scottish Universities (AEF) and Russian Foundation of Basic Research, project 13-05-00784 (BGP). Fieldwork, sample preparation, XRF and ICPAES analyses were supported by MINN project (VAM, JSS, BB and AS). Constructive comments and criticism were gratefully received from official reviewers S. Bergman and A. Martin. This is NORDSIM publication \#415. 


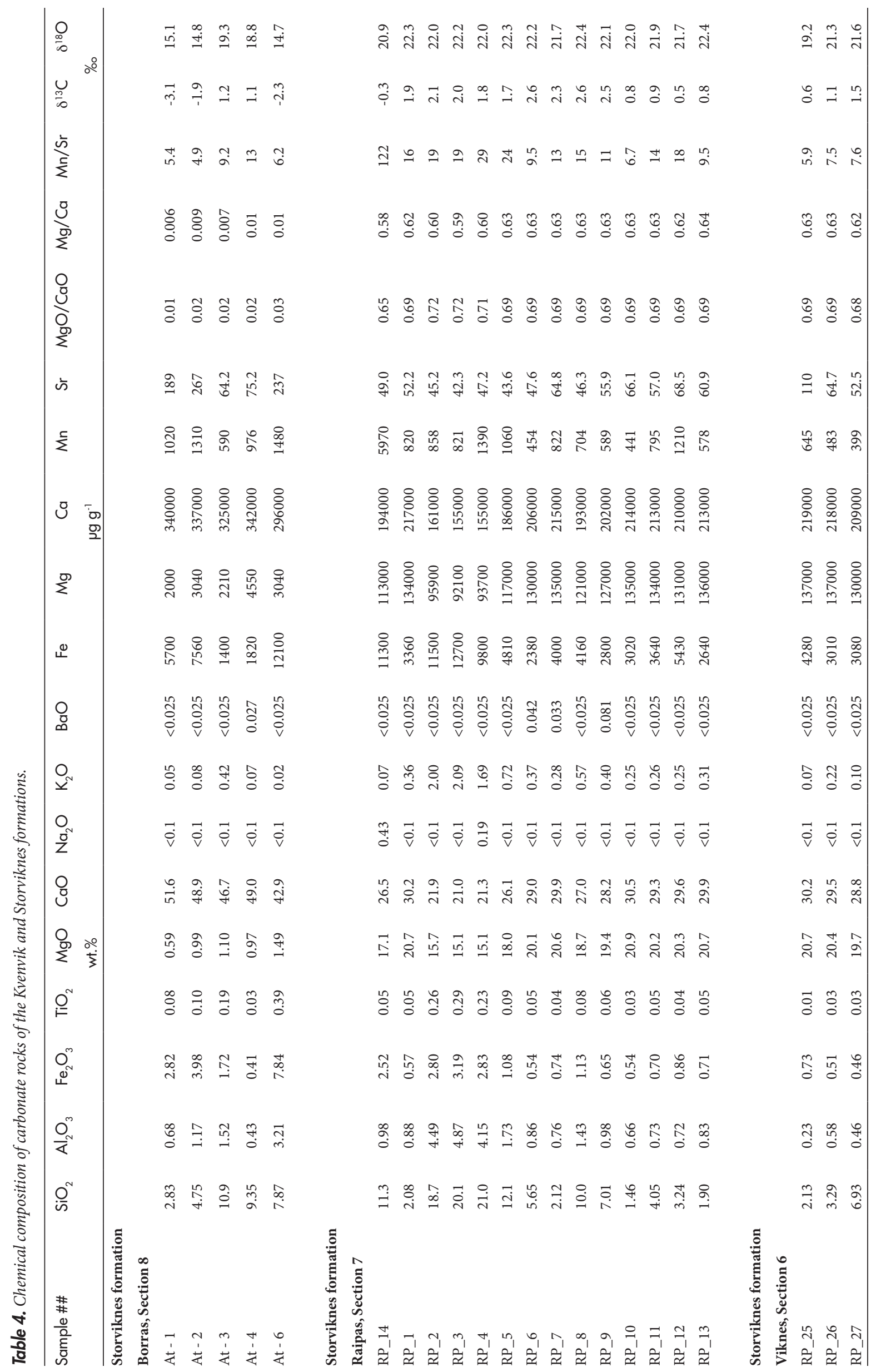




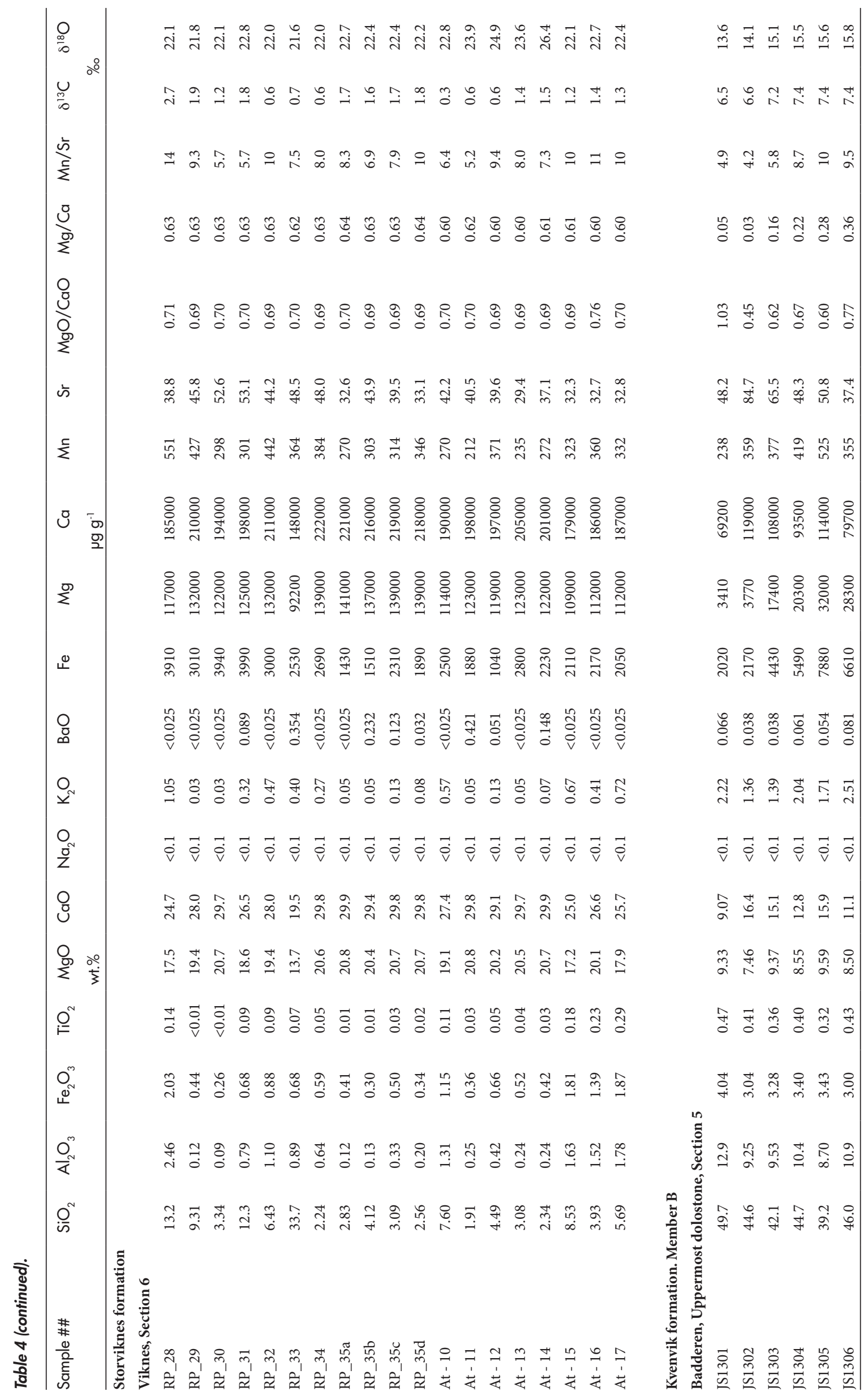




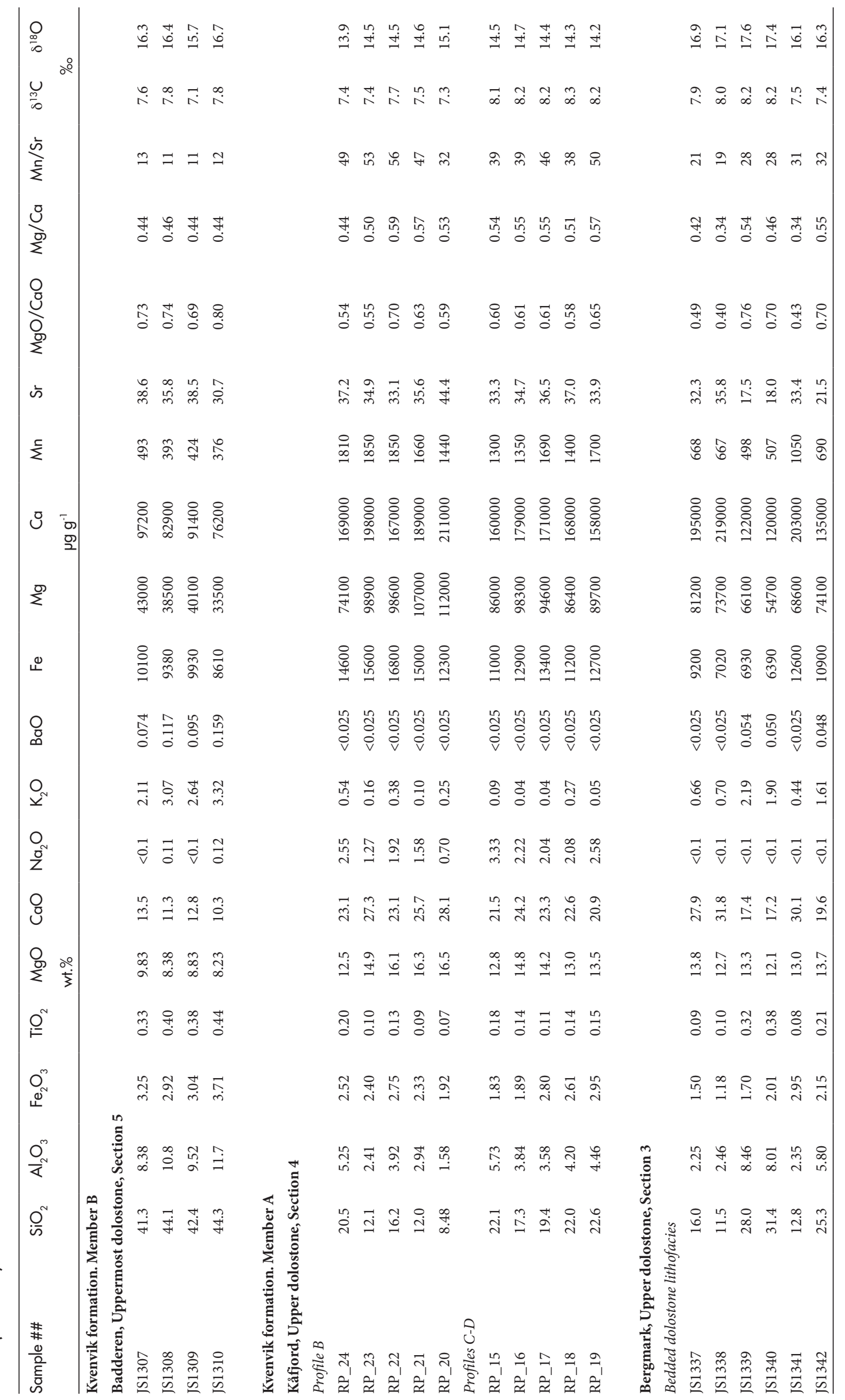




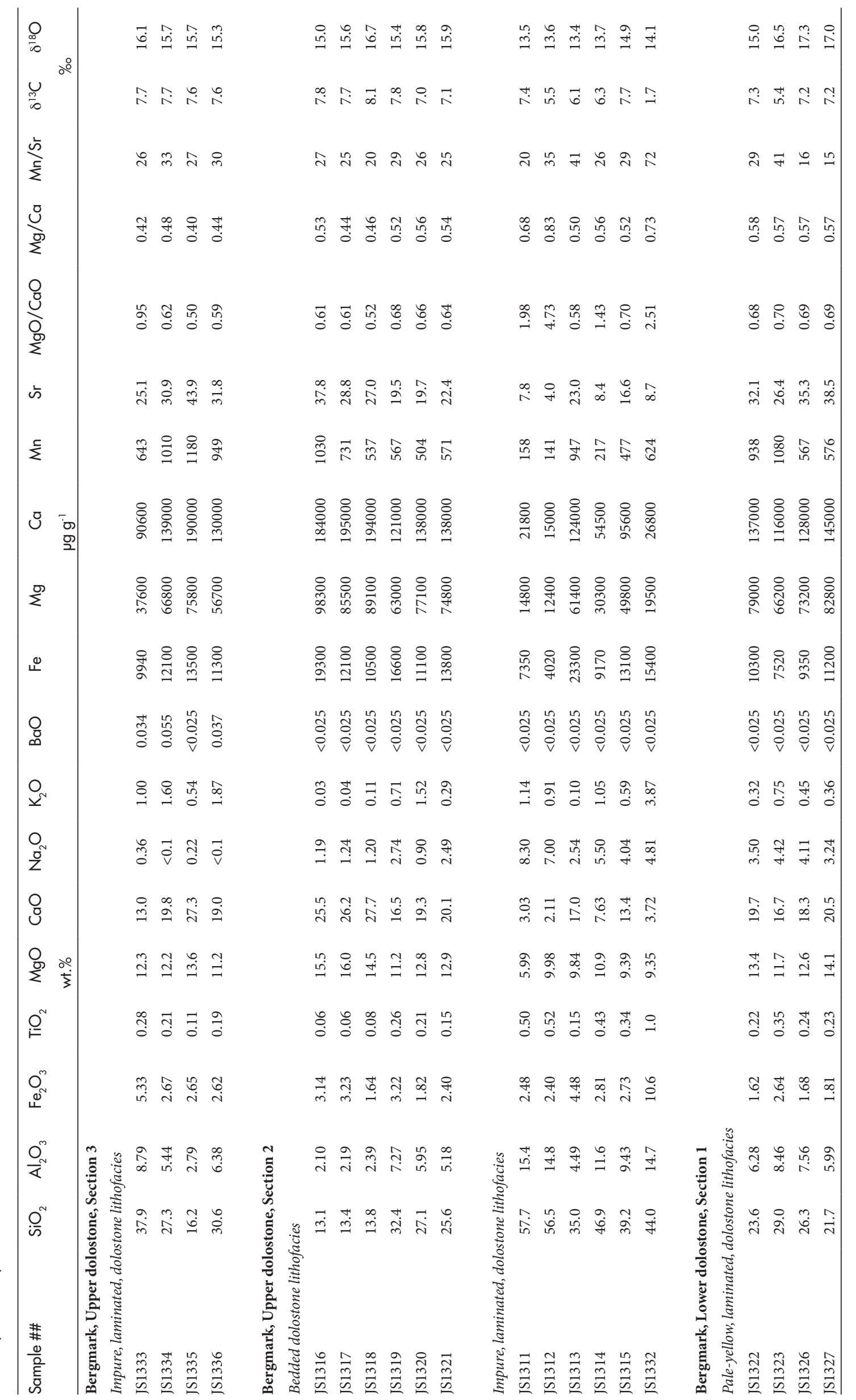




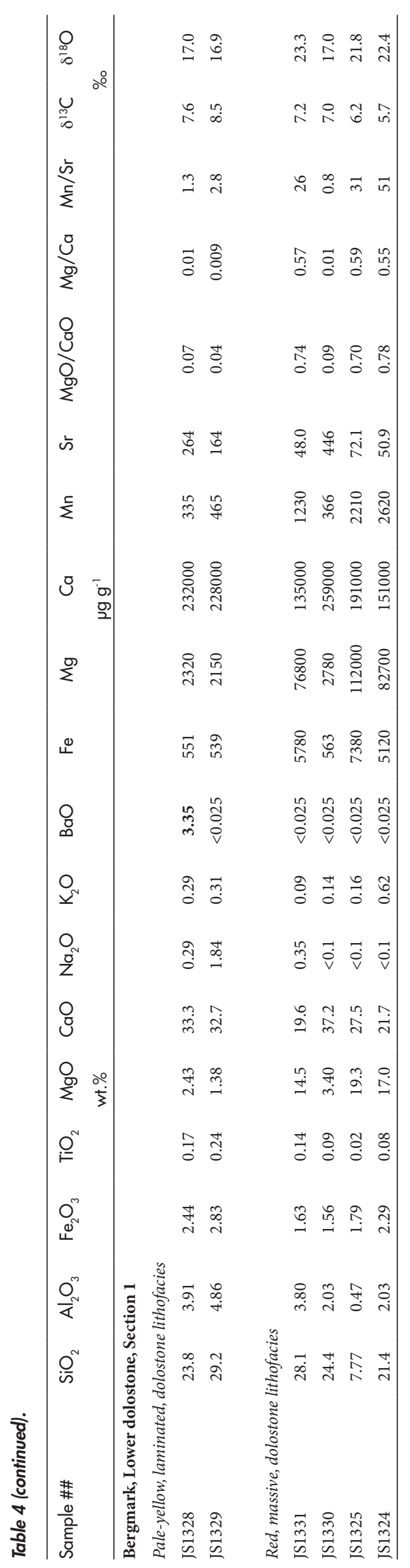

\section{References}

Aitken, J.D. 1967: Classification and environmental significance of cryptalgal limestones and dolomites, with illustrations from the Cambrian and Ordovician of southwestern Alberta. Journal of Sedimentary Petrology 37, 1163-1178.

Amelin,Yu.V.,Heaman,L.M.\&Semenov,V.S. 1995:U-Pbgeochronology of layered mafic intrusions in the eastern Baltic Shield: implications for the timing and duration of Palaeoproterozoic continental rifting. Precambrian Research 75, 31-46.

Banner, J.L. \& Hanson, G.N. 1990: Calculation of simultaneous isotopic and trace element variations during water-rock interaction with applications to carbonate diagenesis. Geochimica et Cosmochimica Acta 54,3123-3137.

Bekker, A., Kaufman, A.J., Karhu, J.A., Beukes, N.J., Swart, Q.D., Coetzee, L.L. \& Eriksson, K.E. 2001: Chemostratigraphy of the Paleoproterozoic Duitschland Formation, South Africa: implications for coupled climate change and carbon cycling. American Journal of Science 301, 261-285.

Bergh, S.G. \& Torske, T. 1986: The Proterozoic Skoadduvarri Sandstone Formation, Alta, northern Norway: a tectonic fan-delta complex. Sedimentary Geology 47, 1-25.

Bergh, S.G. \& Torske, T. 1988: Palaeovolcanology and tectonic setting of a Proterozoic metatholeiitic sequence near the Baltic Shield margin, northern Norway. Precambrian Research 39, 227-246.

Brand, U. \& Veizer, J. 1980: Chemical diagenesis of a multicomponent carbonate system - 1: Trace elements. Journal of Sedimentary Petrology 50, 1219-1236.

Brasier, A.T., Martin, A.P., Melezhik V.A., Prave, AR., Condon, D.J., Fallick, A. E. \& FAR-DEEP Scientists 2013: Earth's earliest global glaciation? Carbonate geochemistry and geochronology of the Polisarka Sedimentary Formation, Kola Peninsula. Precambrian Research 235, 278-294.

Bucher, K. \& Frey, M. 2002: Petrogenesis of Metamorphic Rocks. Springer-Verlag, Berlin, $341 \mathrm{pp}$.

Demicco, R.V. \& Hardie, L.A. 1994: Sedimentary Structure and Early Diagenetic Features of Shallow Marine Carbonate Deposits. Society of Sedimentary Geology, Atlas Series number 1, Tulsa, Oklahoma, USA, 265 pp.

Derry, L.A., Kaufman, A.J. \& Jacobsen, S.B. 1992: Sedimentary cycling and environmental change in the Late Proterozoic: evidence from stable and radiogenic isotopes. Geochimica et Cosmochimica Acta 56, 1317-1329.

Eilu, P. 1994: Hydrothermal alteration in volcano-sedimentary rocks in the Central Lapland Greenstone Belt, Finland. Geological Survey of Finland Bulletin 374, 1-145.

Eilu, P., Pankka, H., Keinänen, V., Kortelainen, V., Niiranen, T. \& Pulkkinen, E. 2007: Characteristics of gold mineralisation in the greenstone belts of northern Finland. Geological Survey of Finland Special Paper 44, 57-106.

Ettner, D.C., Bjørlykke, A. \& Andersen, T. 1994: A fluid inclusion and stable isotope study of the Proterozoic Bidjovagge $\mathrm{Au}-\mathrm{Cu}$ deposit, Finnmark, northern Norway. Mineralium Deposita 29, 16-129.

Fairchild, I.J., Marshall, J.D. \& Bertrand-Sarafati, J. 1990: Stratigraphic shifts in carbon isotopes from Proterozoic stromatolitic carbonates (Mauritania): Influences of primary mineralogy and diagenesis. American Journal of Science 290-A, 46-79.

Frietsch, R., Tuisku, P., Martinsson, O. \& Perdahl, J.-A. 1997: Early Proterozoic $\mathrm{Cu}-(\mathrm{Au})$ and $\mathrm{Fe}$ ore deposits associated with regional $\mathrm{Na}-\mathrm{Cl}$ metasomatism in northern Fennoscandia. Ore Geology Reviews 12, 1-34.

Gärtner, C., Bahlburg, H., Melezhik, V.A., Berndt, J. 2014: Dating Palaeoproterozoic glacial deposits of the Fennoscandian Shield using detrital zircons from the Kola Peninsula, Russia. Precambrian Research 246, 281-295.

Guerrera, A., Peacock, S.M. \& Knauth, L.P. 1997: Large ${ }^{18} \mathrm{O}$ and ${ }^{13} \mathrm{C}$ depletions in greenschist facies carbonate rocks, western Arizona. 
Geology 25, 943-946.

Hannah, J.L., Stein, H.J., Zimmerman, A., Yang, G., Markey, R.J. \& Melezhik, V.A. 2006: Precise $2004 \pm 9$ Ma Re-Os age for Pechenga black shale: Comparison of sulfides and organic material. Geochimica et Cosmochimica Acta 70, A228.

Hannah, J.L., Stein, H.J., Zimmerman, A., Yang, G., Melezhik, V.A., Filippov, M.M., Turgeon, S.C. \& Creaser, R.A. 2008: Re-Os geochronology of a $2.05 \mathrm{Ga}$ fossil oil field near Shunga, Karelia, NW Russia. Abstract, the 33rd International Geological Congress, Oslo.

Hanski, E. J. \& Melezhik, V. A. 2012: Litho- and chronostratigraphy of the Palaeoproterozoic Karelian formations. In Melezhik, V.A., Prave, A.R., Hanski, E.J., Fallick, A.E., Lepland, A., Kump, L.R. \& Strauss, H. (eds.): Reading the Archive of Earth's Oxygenation. Volume 1: The Palaeoproterozoic of Fennoscandia as Context for the Fennoscandian Arctic Russia - Drilling Early Earth Project. Series: Frontiers in Earth Sciences. Springer, Heidelberg, pp. 39-110.

Hanski, E.J., Huhma, H. \& Melezhik, V. A. 2014: New isotopic and geochemical data from the Palaeoproterozoic Pechenga Greenstone Belt, NW Russia: Implication for basin development and duration of the volcanism. Precambrian Research 245, 51-65.

Hudson, J.D. 1977: Stable isotopes and limestone lithification. Journal of Geological Society of London 133, 637-660.

Irvine, T.N. \& Baragar, W.R.A. 1971: A guide to the chemical classification of the common volcanic rocks. Canadian Journal of Earth Sciences 8, 523-548.

Jacobsen, S.B. \& Kaufman, A.J. 1999: The Sr, C and O isotopic evolution of Neoproterozoic seawater. Chemical Geology 161, 37-57.

Karhu J. A., 2005. Paleoproterozoic carbon isotope excursion. In Lehtinen, M., Nurmi, P. A., \& Rämö, O.T. (eds.): Precambrian Geology of Finland-Key to the Evolution of the Fennoscandian Shield. Elsevier, Amsterdam, pp. 669-680.

Karhu, J.A. \& Holland, H.D. 1996: Carbon isotopes and the rise of atmospheric oxygen. Geology 24, 867-879.

Kaufman, A.J. \& Knoll, A.H. 1995: Neoproterozoic variations in the C-isotopic composition of seawater: stratigraphic and biogeochemical implications. Precambrian Research 73, 27-49.

Koistinen, T., Stephens, M.B., Bogatchev, V., Nordgulen, Ø., Wenneström, M. \& Korhonen, J. (Comps.). 2001: Geological Map of the Fennoscandian Shield, Scale 1:2 000 000. Espoo, Trondheim, Uppsala, Moscow.

Krupenik, V.A., Akhmedov, A.M. \& Sveshnikova, K.Yu. 2011a: Structure of the Onega section based on the Onega parametric drillhole. In Glushanin, L.V., Sharov, N.V. \& Shchiptsov, V.V. (eds.): The Onega Palaeoproterozoic Structure (Geology, Tectonics, Deep Structure and Minerageny). Institute of Geology, Karelian Research Centre of RAS, Petrozavodsk, pp. 172-189. (In Russian).

Krupenik, V.A., Akhmedov, A.M. \& Sveshnikova, K.Yu. 2011b: Carbon, oxygen and sulphur isotopic composition of rocks from Ludicoviian and Jatulian Super-Horizons. In Glushanin, L.V., Sharov, N.V. \& Shchiptsov, V.V. (eds.): The Onega Palaeoproterozoic Structure (Geology, Tectonics, Deep Structure and Minerageny). Karelian Science Centre, Petrozavodsk, pp. 250-255. (In Russian).

Kump, L.R., Fallick, A.E., Melezhik, V.A., Strauss, H., Lepland, A., 2013. The Great Oxidation Event. In Melezhik, V.A., Kump, L.R., Fallick, A.E., Strauss, H., Hanski, E.J., Prave, A.R. \& Lepland, A. (eds.): Reading the Archive of Earth's Oxygenation. Volume 3: Global Events and the Fennoscandian Arctic Russia - Drilling Early Earth Project. Series: Frontiers in Earth Sciences. Springer, Heidelberg, pp. 15171533

Kyläkoski, M., Hanski, E. \& Huhma, H. 2012: The Petäjäskoski Formation, a new lithostratigraphic unit in the Paleoproterozoic Peräpohja Belt, northern Finland. Geological Society of Finland Bulletin 84, 85-120.

Land, L.S. 1992: The dolomite problem: stable and radiogenic isotope clues. In Clauer, N. \& Chaudhuri, S. (eds): Isotopic Signatures and Sedimentary Records. Springer-Verlag, pp. 49-68.

Ludwig, K.R. 2001: Users manual for Isoplot/Ex version 2.49, a geochronological toolkit for Microsoft Excel: Berkley, Berkeley Geochronology Center. Special Publication 1a, 56 pp.

Mänttäri, M. 1995: Lead isotope characteristics of epigenetic gold mineralization in the Palaeoproterozoic Lapland greenstone belt, northern Finland. Geological Survey of Finland Bulletin 381, 70 pp.

Martin A.P. \& Condon, D.J. 2013: Review of available radiometric ages constraining the Lomagundi-Jatuli positive isotopic excursion of carbonate carbon. In Melezhik, V.A., Kump, L.R., Fallick, A.E. Strauss, H., Hanski, E.J., Prave, A.R. \& Lepland, A. (eds.): Reading the Archive of Earth's Oxygenation. Volume 3: Global Events and the Fennoscandian Arctic Russia - Drilling Early Earth Project. Series: Frontiers in Earth Sciences. Springer, Heidelberg, pp. 1115-1116.

Martin, A.P. Condon, D.J., Prave A.R., Melezhik, V.A., Lepland, A. \& Fallick, A.E. 2013: Dating the termination of the Palaeoproterozoic Lomagundi-Jatuli carbon isotopic event in the North Transfennoscandian Greenstone Belt. Precambrian Research 224, $160-168$.

Martin, A.P., Condon, D.J., Prave, A.R. \& Lepland, A. 2014: A review of temporal constraints for the Palaeoproterozoic large, positive carbonate carbon isotope excursion (the Lomagundi-Jatuli Event). Earth Science-Reviews 127, 242-261.

McLoughlin, N., Melezhik, V.A., Brasier, A.T. \& Medvedev, P.V. 2013: Palaeoproterozoic stromatolites from the Lomagundi-Jatuli interval of the Fennoscandian Shield. In Melezhik, V.A., Kump, L.R., Fallick, A.E., Strauss, H., Hanski, E.J., Prave, A.R. \& Lepland, A. (eds.): Reading the Archive of Earth's Oxygenation. Volume 3: Global Events and the Fennoscandian Arctic Russia - Drilling Early Earth Project. Series: Frontiers in Earth Sciences. Springer, Heidelberg, pp. 1298-1351

Melezhik, V. A. 2012a: The International Continental Scientific Drilling Program. In Melezhik, V.A., Prave, A.R., Hanski, E.J., Fallick, A.E., Lepland, A., Kump, L.R. \& Strauss, H. (eds.): Reading the Archive of Earth's Oxygenation. Volume 1: The Palaeoproterozoic of Fennoscandia as Context for the Fennoscandian Arctic Russia - Drilling Early Earth Project. Series: Frontiers in Earth Sciences. Springer, Heidelberg, pp. 25-30.

Melezhik, V. A. 2012b: The Imandra/Varzuga Greenstone Belt. In Melezhik, V.A., Prave, A.R., Hanski, E.J., Fallick, A.E., Lepland, A., Kump, L.R. \& Strauss, H. (eds.): Reading the Archive of Earth's Oxygenation. Volume 1: The Palaeoproterozoic of Fennoscandia as Context for the Fennoscandian Arctic Russia - Drilling Early Earth Project. Series: Frontiers in Earth Sciences. Springer, Heidelberg, pp. 249-287.

Melezhik, V. A. \& Hanski, E. J. 2012a: The Early Palaeoproterozoic of Fennoscandia: geological and tectonic settings. In Melezhik, V.A., Prave, A.R., Hanski, E.J., Fallick, A.E., Lepland, A., Kump, L.R. \& Strauss, H. (eds.): Reading the Archive of Earth's Oxygenation. Volume 1: The Palaeoproterozoic of Fennoscandia as Context for the Fennoscandian Arctic Russia - Drilling Early Earth Project. Series: Frontiers in Earth Sciences. Springer, Heidelberg, pp. 33-38.

Melezhik, V. A. \& Hanski, E. J. 2012b: The Pechenga Greenstone Belt. In Melezhik, V.A., Prave, A.R., Hanski, E.J., Fallick, A.E., Lepland, A., Kump, L.R. \& Strauss, H. (eds.): Reading the Archive of Earth's Oxygenation. Volume 1: The Palaeoproterozoic of Fennoscandia as Context for the Fennoscandian Arctic Russia - Drilling Early Earth Project. Series: Frontiers in Earth Sciences. Springer, Heidelberg, pp. 289-385.

Melezhik, V.A., Fallick, A.E., Smirnov, Yu.P. \& Yakovlev, Yu.N. 2003: Fractionation of carbon and oxygen isotopes in ${ }^{13} \mathrm{C}$-rich Palaeoproterozoic dolostones in the transition from mediumgrade to high-grade greenschist facies: a case study from the Kola Superdeep Drillhole. Journal of the Geological Society of London 160, 71-82.

Melezhik, V.A., Fallick, A.E., Rychanchik, D.V. \& Kuznetsov A.B. 2005: Palaeoproterozoic evaporites in Fennoscandia: implications for seawater sulphate, $\delta^{13} \mathrm{C}$ excursions and the rise of atmospheric oxygen. Terra Nova 17, 141-148. 
Melezhik, V.A., Huhma, H., Condon, D.J., Fallick, A.E. \& Whitehouse, M.J. 2007: Temporal constraints on the Paleoproterozoic Lomagundi-Jatuli carbon isotopic event, Geology 35, 655-658.

Melezhik, V. A., Medvedev, P.V. \& Svetov, S.A. 2012: The Onega Basin. In Melezhik, V.A., Prave, A.R., Hanski, E.J., Fallick, A.E., Lepland, A., Kump, L.R. \& Strauss, H. (eds.): Reading the Archive of Earth's Oxygenation. Volume 1: The Palaeoproterozoic of Fennoscandia as Context for the Fennoscandian Arctic Russia - Drilling Early Earth Project. Series: Frontiers in Earth Sciences. Springer, Heidelberg, pp. 387-490.

Melezhik, V.A., Fallick, A.E., Martin, A.P., Condon, D.J., Kump, L.R., Brasier, A.T. \& Salminen, P.E. 2013a: The Palaeoproterozoic perturbation of the global carbon cycle: the Lomagundi-Jatuli isotopic event. In Melezhik, V.A., Kump, L.R., Fallick, A.E., Strauss, H., Hanski, E.J., Prave, A.R. \& Lepland, A. (eds.): Reading the Archive of Earth's Oxygenation. Volume 3: Global Events and the Fennoscandian Arctic Russia - Drilling Early Earth Project. Series: Frontiers in Earth Sciences. Springer, Heidelberg, pp. 1111-1150.

Melezhik, V.A., Fallick, A.E., Filippov, M.M., Deines, Y.E., Črne, A.E., Lepland,A., Brasier,A.T. \& Strauss, H.2013b: Giant Palaeoproterozoic petrified oil field in the Onega Basin. In Melezhik, V.A., Kump, L.R., Fallick, A.E., Strauss, H., Hanski, E.J., Prave, A.R. \& Lepland, A. (eds.): Reading the Archive of Earth's Oxygenation. Volume 3: Global Events and the Fennoscandian Arctic Russia - Drilling Early Earth Project. Series: Frontiers in Earth Sciences. Springer, Heidelberg, pp. 1202-1212.

Melezhik, V.A., Prave, A.R., Brasier, A.T., Lepland, A., Romashkin, A.E., Rychanchik, D.V., Hanski, E.J., Fallick, A.E. \& Medvedev, P.V. 2013c: Tulomozero Formation: FAR-DEEP Holes 10A and 10B. In Melezhik, V.A., Prave, A.R., Fallick, A.E., Hanski, E.J., Lepland, A., Kump, L.R. \& Strauss, H. (eds.): Reading the Archive of Earth's Oxygenation. Volume 2: The Core Archive of the Fennoscandian Arctic Russia - Drilling Early Earth Project. Series: Frontiers in Earth Sciences. Springer, Heidelberg, pp. 773-997.

Melezhik, V.A., Prave, A.R., Lepland, A., Romashkin, A.E., Rychanchik, D.V. \& Hanski, E.J. 2013d: Tulomozero Formation: FAR-DEEP Hole 11A. In Melezhik, V.A., Prave, A.R., Fallick, A.E., Hanski, E.J., Lepland, A., Kump, L.R. \& Strauss, H. (eds.): Reading the Archive of Earth's Oxygenation. Volume 2: The Core Archive of the Fennoscandian Arctic Russia - Drilling Early Earth Project. Series: Frontiers in Earth Sciences. Springer, Heidelberg, pp. 889-945.

Morozov, A.F., Hakhaev, B.N., Petrov, O.V., Gorbachev, V.I., Tarkhanov, G.B., Tsvetkov, L.D., Erinchek, Yu.M., Akhmedov, A.M., Krupenik, V.A. \& Sveshnikova, K.Yu. 2010: Rock-salts in Palaeoproterozoic strata of the Onega depression of Karelia (based on data from the Onega parametric drillhole). Transactions of the Russian Academy of Sciences 435, 230-233. (In Russian).

Nabelek, P.I. 1991: Stable isotope monitors. In Kerrick, D.M. (ed.): Contact Metamorphism, Reviews in Mineralogy 26, pp. 395-435.

Nasuti, A., Roberts, D., Dumais, M.-A., Ofstad, F., Hyvönen, E., Stampolidis, A. \& Rodionov, A. 2015: New high-resolution aeromagnetic and radiometric surveys in Finnmark and North Troms: linking anomaly patterns to bedrock geology and structure. Norwegian Journal of Geology 95, 217-243. http://dx.doi. org/10.17850/njg95-3-10.

Olerud, S. 1988: Davidite-loveringite in early Proterozoic albite felsites in Finnmark, north Norway. Mineralogical Magazine 52, 400-402.

Olesen, O. \& Solli,A., 1985. Geophysical and geological interpretation of regional structures within the Precambrian Kautokeino Greenstone Belt, Finnmark, North Norway. Norges geologiske undersøkelse Bulletin 403, 119-129.

Olesen, O., Roberts, D., Henkel, H., Lile, O.B. \& Torsvik, T.H. 1990: Aeromagnetic and gravimetric interpretation of regional structural features in the Caledonides of West Finnmark and North Troms, northern Norway. Norges geologiske undersøkelse Bulletin 419, 1-24.

Ovchinnikova, G.V., Kusnetzov, A.B., Melezhik, V.A., Gorokhov, I.M., Vasil'eva, I.M. \& Gorokhovsky, B.M. 2007: $\mathrm{Pb}-\mathrm{Pb}$ age of Jatulian carbonate rocks: the Tulomozero Formation in south-eastern Karelia. Stratigraphy and Geological Correlation 4, 20-33. (In Russian).

Pearce, J.A. \& Cann, J.R. 1973: Tectonic setting of basic volcanic rocks determined using trace element analyses. Earth Planetary Science Letter 19, 290-300.

Pharaoh, T., Ramsay, D. \& Jansen, Ø. 1983: Stratigraphy and structure of the northern part of the Repparfjord-Komagfjord Window, Finmark, northern Norway. Norges geologiske undersøkelse Bulletin $68,1-48$.

Puchtel, I.S., Zhuravlev, D.Z., Ashikhmina, N.A., Kulikov, V.S. \& Kulikova, V.V. 1992: Sm-Nd age of the Suisarian suite on the Baltic Shield. Transactions of Russian Academy of Sciences 326, 706-711. (In Russian).

Puchtel, I.S., Arndt, N.T., Hofmann, A.W., Haase, K.M., Kröner, A., Kulikov, V.S., Kulikova, V.V., Garbe-Schönberg, C.-D. \& Nemchin, A.A. 1998: Petrology of mafic lavas within the Onega plateau, Central Karelia: evidence for the $2.0 \mathrm{Ga}$ plume-related continental crustal growth in the Baltic Shield. Contributions to Mineralogy and Petrology 130, 134-153.

Reuschel, M., Melezhik, V. A., Whitehouse, M.J., Lepland, A., Fallick, A.E. \& Strauss, H. 2012: Isotopic evidence for a sizeable seawater sulfate reservoir at 2.1 Ga. Precambrian Research 192-195, 78-88.

Schmitz, M.D. \& Schoene, B. 2007: Derivation of isotope ratios, errors and error correlations for $\mathrm{U}-\mathrm{Pb}$ geochronology using ${ }^{205} \mathrm{~Pb}-{ }^{235} \mathrm{U}-$ $\left({ }^{233} \mathrm{U}\right)$-spike isotope dilution thermal ionization mass spectrometric data. Geochemistry, Geophysics, Geosystems 8, Q08006, http://dx.doi. org/10.1029/2006GC00149210.1029/2006GC001492.

Shieh, Y.M. \& Taylor, H.P. 1969: Oxygen and carbon isotope studies of contact meta-morphism of carbonate rocks. Journal of Petrology 10, 307-331.

Siedlecka, A., Krill, A.G., Often, M., Sandstad, J.S., Solli, A., Iversen, E. \& Lieungh, B. 1985: Lithostratigraphy and correlation of the Archaean and Early Proterozoic rocks of Finnmarksvidda and the Sørvaranger district. Norges geologiske undersøkelse Bulletin 403, 7-36.

Skuf'in, P.K. \& Bayanova, T.B. 2006: Early Proterozoic central-type volcano in the Pechenga Structure and its relation to the orebearing gabbro-wehrlite complex of the Kola Peninsula. Petrology 14, 609-627.

Strauss, H., Melezhik, V.A., Reuschel, M., Fallick, A.E., Lepland, A. \& Rychanchik, D.V. 2013: Abundant marine calcium sulphates: radical change of seawater sulphate reservoir and sulphur cycle. In Melezhik, V.A., Kump, L.R., Fallick, A.E., Strauss, H., Hanski, E.J., Prave, A.R. \& Lepland, A. (eds.): Reading the Archive of Earth's Oxygenation. Volume 3: Global Events and the Fennoscandian Arctic Russia - Drilling Early Earth Project. Series: Frontiers in Earth Sciences. Springer, Heidelberg, pp. 1169-1194.

Sun, S.S. \& McDonough, W.F. 1989: Chemical and isotopic systematics of oceanic basalts; implications for mantle composition and processes. In Saunders, A.D. \& Norry, M.J. (eds.): Magmatism in the Ocean Basins, Geological Society Special Publications 42, pp. 313-345.

Tuisku, P. 1985: The origin of scapolite in the Central Lapland schist area, northern Finland: preliminary results. Geological Survey of Finland Bulletin 331, 159-173.

Vanhanen, E. 2001: Geology, mineralogy and geochemistry of the Fe$\mathrm{Co}-\mathrm{Au}-(\mathrm{U})$ deposits in the Paleoproterozoic Kuusamo Schist Belt, northeastern Finland. Geological Survey of Finland Bulletin 399, 287 pp.

Veizer, J. 1983: Chemical diagenesis of carbonates: theory and application of the trace element technique. In Arthur, M.A., Anderson, T.F., Kaplan, I.R., Veizer, J., Land, L.S. (eds.): Stable Isotopes in Sedimentary Geology, SEPM Short Course No. 10. Society for Sedimentary Geology, Dallas (Chapter 3), pp. 1-100.

Veizer, J., Clayton, R.N. \& Hinton, R.W. 1992: Geochemistry of Precambrian carbonates: IV. Early Paleoproterozoic $(2.25 \pm 0.25$ $\mathrm{Ga})$ seawater. Geochimica et Cosmochimica Acta 56, 875-885. 
Vik, E. 1985: En geologisk undersøkelse av kobbermineraliseringene $i$ Alta-Kvoenangenvinduet, Troms or Finnmark. PhD Thesis, University of Trondheim, NTH, Geological Institute, 295 pp. (In Norwegian).

Vrevsky, A.B., Bogomolov, E.S., Zinger, T.F. \& Sergeev, S.A. 2010: Polychronic sources and isotopic age of the volcanogenic complex (Arvarench unit) of the Imandra-Varzuga structure, Kola Peninsula. Doklady (Transactions) of the Russian Academy of Sciences 431, 386389.

Whitehouse, M.J. \& Kamber, B.S. 2005: Assigning dates to thin gneissic veins in high-grade metamorphic terranes: a cautionary tale from Akilia, Southwest Greenland. Journal of Petrology 46, 291-318.

Whitehouse, M.J., Kamber, B.S. \& Moorbath, S. 1999: Age significance of $\mathrm{U}-\mathrm{Th}-\mathrm{Pb}$ zircon data from early Archaean rocks of west Greenland - a reassessment based on combined ion-microprobe and imaging studies. Chemical Geology 160, 201-224.

Wiedenbeck, M., Allé, P., Corfu, F., Griffin, W.L., Meier, M., Oberli, F., Von Quadt, A., Roddick, J.C. \& Spiegel, W. 1995: Three natural zircon standards for $\mathrm{U}-\mathrm{Th}-\mathrm{Pb}, \mathrm{Lu}-\mathrm{Hf}$, trace element and REE analyses. Geostandards Newsletter 19, 1-3.

Zwaan, K.B. \& Gautier, A.M. 1980: Alta og Gargia, Beskrivelse til de berggrunnsgeologiske kart 1834 I og 1934 IV - M 1:50000 (Med fargetrykte kart). Norges geologiske undersøkelse Skrifter 32, 1-47. (In Norwegian with English abstract).

Åm, K. 1975: Aeromagnetic basement complex mapping north of latitude $62^{\circ} \mathrm{N}$, Norway. Norges geologiske undersøkelse 316, 351-374. 